\title{
You're Gonna Need a Bigger Boat: Alternatives to the UN Security Council for Enforcing Nuclear Disarmament and Human Rights
}

David A. Koplow

Georgetown University Law Center, koplow@law.georgetown.edu

This paper can be downloaded free of charge from:

https://scholarship.law.georgetown.edu/facpub/1803

29 Harv. Hum. Rts. J. 135-201 (2016)

This open-access article is brought to you by the Georgetown Law Library. Posted with permission of the author. Follow this and additional works at: https://scholarship.law.georgetown.edu/facpub

Part of the Human Rights Law Commons, and the National Security Law Commons 


\title{
You're Gonna Need a Bigger Boat: Alternatives to the UN Security Council for Enforcing Nuclear Disarmament and Human Rights
}

\author{
David A. Koplow ${ }^{1}$
}

\section{INTRODUCTION}

There is a serious problem with the Security Council. That institutionendowed by the United Nations Charter with "primary responsibility for the maintenance of international peace and security"2 - has stood at the apex of the global political, diplomatic, and legal structure for seventy years, responding (more or less) to the full panoply of incessant dangers and provocations. The Charter could not have been crafted or sustained without it, and the Security Council has, at least, assisted in preserving a measure of fundamental world order-in particular, it has helped avoid the cataclysm of a World War III.

But a central feature of the organization-the veto power wielded by the five permanent members (P5), China, France, Russia, the United Kingdom, and the United States-has become critically dysfunctional. It has too often frustrated the will of the international community, holding essential enforcement actions hostage to the implacable will of a single outlier state.

In two areas in particular-one newly emerging on the international scene, the other even more futuristic - the world needs a viable alternative to the Security Council. A mechanism must be found to counteract the Security Council's over-deterrent effect on authorizing the use of military force and to empower a concerted, lawful response to these two most severe challenges to global aspirations without continuing to cede a dispositive nyet power to each of the P5.

The first of these currently under-enforced areas of law concerns international human rights. The world has laboriously drafted, signed, and

1. Professor of Law, Georgetown University Law Center. The author gratefully thanks Abraham Shanedling and William (Collmann) Griffin for their superb research assiscance on this project; Mabel Shaw for outstanding library support; and James E. Baker, Barry M. Blechman, Karl S. Chang, Michael J. Glennon, Duncan B. Hollis, David S. Jonas, Barry Kellman, Amy Uelmen, David Wippman, and the members of the Georgetown Law Center summer workshop for their thoughtful and useful comments on earlier drafts of this manuscript.

2. U.N. Charter art. 24, ๆ 1. 
brought into force a stream of international agreements designed to suppress the worst atrocities of genocide, war crimes, and crimes against humanity, especially when committed by a government against segments of its own population. Unfortunately, giving effect to these lofty ambitions too often remains a cruel illusion: when the outrages occur (in Rwanda, Darfur, or Syria, to cite only a few of the most conspicuous examples), too often the global response is delayed, timid, and incomplete. Sometimes, the exercise or mere threat of the veto has paralyzed the Security Council, and the world has collectively sat on its hands. Other times, an individual state or a "coalition of the willing," horrified by the human carnage and frustrated by the Security Council's fecklessness, has undertaken a unilateral intervention-but that action (successful or not) is widely regarded as lacking a valid basis in contemporary international law.

In partial response to this dilemma, the world community has lumbered toward a concept of "responsibility to protect" (R2P). As explored in greater detail infra, this notion declares these atrocities to be of profound global concern, and if no other recourse is available, R2P justifies intervention from outside states. In what I call the "soft" version of R2P, military intercession is ordinarily allowable only when the Security Council provides authorization, in conformity with black-letter international law. In its "hard" version, R2P would justify a forceful incursion even without a Security Council blessing - but this more capacious rejoinder is widely regarded as legally inconsistent with the Charter obligations.

Exploration of the second problematic area of Security Council shortcomings requires peering further into the future. Advocates of nuclear arms control, emboldened by a recent surge of interest in the concept of "getting to zero" (i.e., completely eliminating nuclear weapons) have contemplated the future workings of an imaginable nuclear disarmament regime. Obviously, any realistic "Zero Treaty" would require highly efficacious mechanisms for verification of compliance (to detect, in a timely fashion, any violations of the treaty obligations) and for rigorous enforcement (to respond promptly and authoritatively in a manner that denies to the violator any militarily-significant benefits). In particular, the ultimate fallback has to embrace a military option-to strike and disrupt or destroy the cheater's illegal nuclear weapons-related facilities and forces.

Ordinarily, it would require a decision of the Security Council to authorize any such corrective military action, determining that the violation constituted a "threat to the peace." 3 But what if the P5 were not united on the question-what if the violator was allied with (or was) one of the permanent members, and the cudgel of the veto was wielded? The Zero Treaty would fail, or it would rely for enforcement upon a unilateral military strike by an especially concerned and capable self-nominating state or group,

3. Id. art. 39. 
whose vigilante action (even if welcomed by most parties to the treaty) would rightly be characterized as inconsistent with extant international law.

One possible remedy for these two categories of poignant dilemmas would be to "contract around" the Security Council. That is, the states concluding the new human rights or disarmament treaty could invest the legal power to authorize a use of military force in a new, veto-proof body. For example, an amendment or protocol to the 1948 Genocide Convention, ${ }^{4}$ or a new, muscular general purpose R2P Treaty could specify that the parties, acting via a specified supermajority vote of all members or of a designated executive council, could license a remedial use of military force when necessary to protect fundamental human rights. In the same vein, the Zero Treaty that created the nuclear disarmament obligation could also enforce it by vesting in a newly-established, veto-proof body the power to invoke military sanctions against an unrepentant violator.

But the Charter was specifically designed not to be subject to such facile circumnavigation. First, Article 103 precisely contemplates the possibility of a disconnect between the Charter and any other treaty, and it endows the Charter with a superior, "constitutional" character. It specifies that in the event of a conflict between the Charter and any other agreement-regardless of which instrument is newer-the obligations of the Charter shall

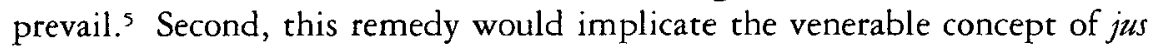
cogens, which concerns peremptory norms of international law from which no derogation is permissible. The doctrine of jus cogens has not been fully elaborated, and there is little authoritative judicial interpretation or state practice on point, but it is generally accepted that the fundamental guarantee of the Charter's Article 2(4) would be included: member states "shall refrain from the threat or use of force against the territorial integrity or political independence of any state." 6 As elaborated infra, any treaty provision incompatible with a norm of $j u s$ cogens is void.

How, then, can these competing objectives and legal principles be reconciled? How can the world develop the necessary mechanisms for acquitting its profound concern for human rights and nuclear disarmament without foundering on the Security Council veto? Is there a "bigger boat" that can rescue us from this conflict of legal and political interests?

This Article explores that conundrum in the following sequence. After this Introduction, Part I provides a concise background orientation to the body of orthodox international law regarding the resort to military force, jus ad bellum. In a nutshell, there are only two permissible bases for the legal use of force under the Charter system: actions undertaken in individual or

4. Convention on the Prevention and Punishment of the Crime of Genocide, Dec. 9, 1948, 78 U.N.T.S. 277, 28 I.L.M. 754 [hereinafter Genocide Convention].

5. U.N. Charter art. 103.

6. Id. art. 2 , ๆ 4 . 
collective national self-defense pursuant to Article 51 of the Charter, ${ }^{7}$ and actions authorized by the Security Council pursuant to chapter VII of the Charter. ${ }^{8}$ Anything else-no matter how earnestly the affected states and populations may desire it -is a per se violation of international law.

Part II then explores the concept of R2P, focusing on the variant that would purport to authorize a use of military force even without Security Council authorization in cases of egregious, persistent violations of fundamental human rights. When the P5 are deadlocked, the world either fails to do anything effective in response to the atrocities, or a self-appointed vanguard violates existing international law in order to save lives. Either outcome is undesirable; perhaps a treaty-based fix is in order.

Part III provides a similar analysis of nuclear disarmament, where the problem is even more pronounced in certain respects. The vital national security interests at stake likely preclude the adoption of any nuclear abolition treaty that does not provide a veto-proof enforcement mechanism. While countries today might be willing to join a human rights treaty even if it is not perfectly enforceable, the leading states seeking a Zero Treaty cannot safely give up their own nuclear weapons unless they enjoyed ironclad assurances that a single P5 recalcitrant cannot block corrective action.

$\mathrm{R} 2 \mathrm{P}$ remains a novel, emerging doctrine, but it has already attracted a torrent of scholarly and practitioner commentary, 9 including the concept of authorizing the international use of military force without a Security Council permission slip, pursuant to a new treaty-created mechanism. This Article, however, is the first to extend comparable analysis to the equally vexing and urgent question of nuclear disarmament. The hope is that juxtaposition of these two otherwise unrelated areas will provide points of comparison that can generate fresh insights for both.

Part IV explores the validity of the contemplated work-around, to evade the Security Council via a treaty clause delegating enforcement power to a new body. The impediments to this course are evaluated, as is the notion that state consent provides a justification for dodging the Charter's apparent restrictions. Under modern international law, a state may voluntarily accept many restrictions upon its sovereign autonomy that could not be

7. Id. art. 51 .

8. Id. arts. 39,42 .

9. See generally INT'L COALITION FOR THE Resp. TO PROTECT, http://responsibilitytoprotect.org/ index.php/about-rtop (last visited Feb. 24, 2016) [hetps://perma.cd/7RP8-FH6V]; GLOB. CTR. FOR THE Resp. то Protect, http://www.globalr2p.org/about_us (last visited Feb. 24, 2016) [hetps://perma.cc/ ETL8-8USL]; Asia PAC. CTR. FOR THE Resp. to Protect, http://www.r2pasiapacific.org/ (last visited Feb. 24, 2016) [https://perma.cc/BD8A-RQHP]; Glob. ResP. To PROTECT, http://www.brill.com/ global-responsibility-protect (last visited Feb. 24, 2016) [https://perma.cc/T7AE-CAJQ] (describing focus of leading journal dedicated to R2P); Our Work, R2P MonrTor, http://www.globalr2p.org/ our_work/r2p_monitor (last visited Feb. 24, 2016) [https://perma.cc/WRT3-RT9B] (describing work of bimonthly publication "applying an R2P lens to situations where populations are at risk of, or are currently facing, mass atrocity crimes"). 
legitimately forced upon it-but may it even provide, in advance, an irrevocable consent to use of military force against itself?

Ultimately, Part V concludes that an R2P Treaty and a Zero Treaty could legitimately escape the clutches of the Security Council and enable the proponent states to pursue their progressive agendas. This is a close case, but the Article argues that the parties could validly establish and empower new international organizations as alternative, veto-proof custodians for the legal use of military force in these two critically important, factually limited contexts. While such a strategy might seem to degrade the unique status and majesty of the Security Council, it is in truth more expressive of states' emerging collective will and more reflective of their recurrent patterns of practice. Taking this course would thus create a more realistic alignment of international law and international behavior.

\section{Part I: International Law on the Use of Military Force}

The touchstone for jus ad bellum is Article 2(4) of the Charter, which provides: "All Members shall refrain in their international relations from the threat or use of force against the territorial integrity or political independence of any state, or in any other manner inconsistent with the Purposes of the United Nations." 10

Pursuant to this expansive dictate, most unconsented international applications of organized violence (whether or not officially declared as "war") are per se illegal - a dramatic revision of the prior international law regarding armed combat. ${ }^{11}$ The Charter extends this protective umbrella indiscriminately to all states, even those of a markedly dictatorial or abusive bent, no matter how heavily and threateningly armed. ${ }^{12}$

10. U.N. Charter art, 2, ๆ 4.

11. See, e.g., W. Michael Reisman, Coercion and Self-Determination: Construing Charter Article 2(4), 78 AM. J. INT'L L. 642 (1984) ("The United Nations Charter introduced to international politics a radically new notion: a general prohibition of the unilateral resort to force by states."); Claus Kress, Major Post-Westphalian Sbifts and Some Important Neo-Westphalian Hesitations in the State Practice on the International Law of the Use of Force, 1 J. ON USE OF FORCE AND INT'L L. 11, 13 (2014) (referring to Article 2(4) as "one of the UN Charter's most important legal novelties"); Nico Schrijver, Article 2(4) History and Present Content, in The Oxford Handbook of the Use of Force in International Law 465 (Marc Weller ed., 2015).

12. See, e.g., Louis Henkin, The Invasion of Panama under International Law: A Gross Violation, 29 Colum. J. Transnat'L L. 293, 298 (1991) [hereinafter Henkin, Gross Violation] (asserting that international law has rejected any claimed right to intervene militarily inside another state in order to vindicate democracy); John Lawrence Hargrove, Intervention by Invitation and the Politics of the New World Order, in Law and Force in the New International Order 113 (Lori Fisler Damrosch \& David J. Scheffer eds., 1991) ("International law protects against the use of force even those states that may not be in full compliance with their international legal obligations, including obligations about individual rights."); Oona Hathaway et. al., Consent-Based Humanitarian Intervention: Giving Sovereign Responsibility Back to the Sovereign, 46 CorNell. INT'L. L.J. 499, 502 (2013) [hereinafter Hathaway, Consent-Based] (asserting that the international law protection against the threat or use of force applies "even when a state is engaged in an open and notorious violation of human rights law"); Malvina Halberstam, The Copenhagen Document: Intervention in Support of Democracy, 34 Harv. INT'L L.J. 163, 168-69 (1993) (reporting the 
Article 2(7) of the Charter reflects a parallel injunction, stating:

Nothing contained in the present Charter shall authorize the United Nations to intervene in matters which are essentially within the domestic jurisdiction of any state or shall require Members to submit such matters to settlement under the present Charter, but this principle shall not prejudice the application of enforcement measures under Chapter VII. ${ }^{13}$

Although far from unambiguous, this passage reflects a deep-seated global sentiment against outside interventions-a principle predating 1945 that has been repeatedly re-emphasized to universal acclaim. ${ }^{14}$ For matters that touch the traditional core components of state sovereignty-such as a government's treatment of its own citizens, or its decisions about how to arm itself-the bulwarks against outsiders insinuating themselves into erstwhile national decision-making are substantial. ${ }^{15}$

Justifications for the Use of Force. International law formally recognizes only two relevant exceptions to the broad mandate against international military ventures. First, under Article 51: "Nothing in the present Charter shall

debare about whether "the UN Charter condemns equally the use of force in support of the most despotic dictator and the use of force in support of a freely elected government"); Military and Paramilitary Activities in and Against Nicaragua (Nicar. v. U. S.), Judgement, 1986 I.C.J. 14, I 263 (June 27) (" $[\mathrm{ICJ}]$ cannot contemplate the creation of a new rule opening up a right of intervention by one state against another on the ground that the latter has opted for some particular ideology or political system.").

13. U.N. Charter art. 2, I 7.

14. See, e.g., Montevideo Convention on the Rights and Duties of States art. 8, Dec. 26, 1933, 49 Stat. 3097, 165 L.N.T.S. 19; G.A. Res. 2131 (XX), Resolution on the Inadmissibility of Intervention in the Domestic Affairs of States and the Protection of Their Independence and Sovereignty (Dec. 21, 1965); G.A. Res. 2625 (XXV), Declaration on Principles of International Law Concerning Friendly Relations and Co-Operation among States in Accordance with the Charter of the United Nations (Oct. 24, 1970); The Corfu Channel Case (U.K. v. Alb.), Judgement, 1949 I.C.J. 4, 34-35 (April 9); Milirary and Paramilicary Activities in and Against Nicaragua (Nicar. v. U.S.), Judgement, 1986 I.C.J. 14, If 205, 246, 258 (June 27); ANn VAN Wrnen Thomas \& A.J. ThOmas, JR., Non-Intervention: The LAw AND ITS IMPORT IN THE AMERICAS 55-64, 142-55 (1956); Louise Doswald-Beck, The Legal Validity of Military Intervention by Invitation of the Government, 56 BrIT. Y.B. INT'L L. 189, 207-13 (1985) [hereinafter Doswald-Beck, Legal Validity] (assessing the "inadmissibility of interference in the internal affairs of states"); P.H. Winfield, The Grounds of Intervention in International Law, 5 BRIT. Y.B. INT'L L. 149 (1924) (comparing the international law against intervention to the international law against slavery, even in the pre-Charter era); Tom J. Farer, The United States as Guarantor of Democracy in the Caribbean Basin: Is There a Legal Way?, 10 HuM. RTs. Q. 157, 162 (1988) [hereinafter Farer, Guarantor of Democracy\}; David Wippman, Change and Continuity in Legal Justifications for Military Intervention in Internal Conflict, 27 Colum. Hum. RTs. L. Rev. 435 (1995-96) thereinafter Wippman, Change and Contimuity in Legal Justifications].

15. See, e.g., Eliav Lieblich, Intervention and Consent: Consensual Forcible Interventions in Internal Armed Conflicts as International Agreements, 29 B.U. INT'L L.J. 337, 344-45 (2011) (referring to the principle of non-intervention as being "centuries-old" and entrenched in customary law); Lori Fisler Damrosch, Changing Conceptions of Intervention in International Law, in EMERGing NOrMS OF Justified INTER veNTION 91 (Carl Kaysen \& Laura W. Reed eds., 1993) (tracing the historical evolution of the concept of intervention); Hathaway, Consent-Based, stpra note 12, at 506 n.30 (supporting the proposition that the principle of non-intervention is part of customary international law); Sean D. MUrpHy, Humanitarian Intervention: The United Nations in an Evolving World Order (1996) [hereinafter Murphy, Humanitarian Intervention]. 
impair the inherent right of individual or collective self-defense if an armed attack occurs against a Member of the United Nations, until the Security Council has taken the measures necessary to maintain international peace and security." 16

Many argue that this "inherent right" applies even a bit before the specified "armed attack occurs." That is, there is (or should be) a right to use force in "anticipatory self-defense," if a state accurately perceives that it is about to be victimized by another's aggression, and that a proportionate measure of shooting first is necessary to blunt the pending offensive. ${ }^{17}$ But that looming threat must be "imminent," meaning, in the classic phraseology of the nineteenth century Caroline case, that "the necessity of that selfdefense is instant, overwhelming, and leaving no choice of means and no moment for deliberation." 18 If negotiation and reasonable accommodation are still possible, or if the first explosions of ordnance are still speculative or in the future, then the moment of "necessity" has not arrived, and international law does not authorize the use of "preemptive" or "preventative" uses of force. ${ }^{19}$

16. U.N. Charter art. 51; see also Int'l L. Comm'n., Draft Articles on Responsibility of States for Internationally Wrongful Acts, with Commentaries (2001), http://legal.un.org/ilc/texts/instruments/english/commentaries/9_6_2001.pdf [https://perma.cc/RW76-KXTK] [hereinafter Int'l L. Comm'n, Draft Articles] (discussing law of self-defense).

17. See Thomas M. Franck, Who Killed Article 2(4)? Or: Changing Norms Governing the Use of Force by States, 64 Am. J. INT'L L., 809, 820-22 (1970) [hereinafter Franck, Wbo Killed]; David Wippman, The Nine Lives of Article 2(4), 16 MrNs. J. INT'L L. 387, 398-99 (2007) [hereinafter Wippman, Nine Lives]; John Alan Cohan, The Bush Doctrine and the Emerging Norm of Anticipatory Self-Defense in Customary International Law, 15 PACE INT'L L. REV. 283, 314-22 (2003) (analyzing the customary international law of self-defense); Louise Arimatsu \& Michael N. Schmitt, Attacking "Islamic State" and the Khorasan Group: Surveying the International Law Landscape, 53 Colum. J. Transnat'L. L. Bull. 1, 16-19 (2014) (discussing anticipatory self-defense); Barry E. Carter \& Allen S. Weiner, International Law 964-68 (6th ed. 2011) (discussing anticipatory and preemptive self-defense); Timothy L.H. McCormack, Self-Defense in International Law: The Israeli Raid on the Iraq Nuclear Reactor 111-49 (1996). But see Ian Brownlie, International Law and the Use of Force by States 257-61, 275-78 (1963); Michael J. Glennon, The Fog of Law: Self-Defense, Inberence, and Incoberence in Article 51 of the United Nations Charter, 25 Harv. J.L. AND PuB. POL'y 539, 547 (2002) thereinafter Glennon, Fog of $L a w]$ (arguing that the proposition that the Charter permits anticipatory self-defense is unpersuasive).

18. Regarding the Caroline case, see British-American Diplomacy: The Caroline Case, Yale Law ScH., Avalon Project (2008), http://avalon.law.yale.edu/19th_century/br-1842d.asp (note especially the letter from Daniel Webster to Lord Ashburton, August 6, 1842) [https://perma.cc/3QS8-29WD] [hereinafter Avalon Project]. This was an exchange of US and British diplomatic notes, addressing a dispure arising in 1837 when British forces in Canada entered US territory and attacked a small steamship that had been used to service trans-border rebels; the correspondence articulated the standards for "self-defense" that still underpin international law today. See id.

19. The dividing line between anticipatory and preemptive or preventive self-defense is often obscure. See Carter \& Weiner, supra note 17, at 964-68; Noam Lubell, The Problem of Imminence in an Uncertain World, in The Oxford Handbook of the Use of Force in InTernational Law 697 (Marc Weller ed., 2015). President George W. Bush's administration had sought to adapt the concept of "imminent threat" to justify even a preemptive attack in the case of weapons of mass destrucrion, where risk of waiting too long could be severe. See National Security Strategy of the United States, GEORGE W. BuSH WhITE House ARCHIVes (2002), http://georgewbush-whitehouse.archives.gov/nsc/nss/2002/ print/nss5.html [https:/perma.cc/BA8T-7SX5]; Wolf Blitzer, Search for the 'Smoking Gun', CNN (Jan. 10, 2003, 5:58 PM), http://www.cnn.com/2003/US/01/10/wbr.smoking.gun/index.html?_s=PM:US [https://perma.cc/PWX8-NMFD] (statement of National Security Advisor Condoleezza Rice) ("The 
Force may also be exercised in "collective" self-defense, where outsiders are coming to the aid of a victim of aggression, even if they are not directly threatened themselves, but the state being rescued must "request" that assistance. ${ }^{20}$ Additionally, while international law broadly allows assistance from one state to the government of another in order to support the recipient's struggle against foreign aggression or domestic turmoil, it generally does not tolerate outside assistance to sub-national actors who are rising in resistance to their own government. International law would classify such cases of intervention as unwarranted "intervention."

The second general legal basis for the invocation of military force is established by Chapter VII of the Charter in which the Security Council is authorized to "determine the existence of any threat to the peace, breach of the peace, or act of aggression" and to "make recommendations, or decide what measures shall be taken." ${ }_{21}$ A "decision" by the Security Council is particularly impactful: under Article 25, all members "agree to accept and carry our" 22 those decisions, affording the Security Council a unique lawmaking power which binds all members to obey. ${ }^{23}$

In response to the worst provocations, the Security Council "may take such action by air, sea, or land forces as may be necessary to maintain or restore international peace and security." ${ }^{24}$ As originally conceptualized, the Security Council would have at its disposal its own dedicated military forces to dispatch for these functions; ${ }^{25}$ in practice, the routine has been instead

problem here is that there will always be some uncertainty about how quickly he can acquire nuclear weapons. But we don't want the smoking gun to be a mushroom cloud."); see also G.A. Res. 63/308 (Oct. 7, 2009); U.N. Secretary-General's High-Level Panel on Threats, Challenges and Change, A more Sectre World: Our Shared Responsibility, at 140 n.104 (2004) [hereinafter High-Level Panel] (arguing against a "preventive" use of military force and asserting that in a situation in which the threatened use of force is not imminent, states should have recourse to the Security Council); Henkin, Gross Violation, supra note 12, at 306-08 (reporting US government positions on the question of a right to anticipatory self-defense); Wippman, Nine Lives, supra note 17, at 399; Jean Allain, The True Cballenge to the United Nations System of the Use of Force: The Failures of Kosowo and lraq and the Emergence of the African Union, 8 MAX PLANCK Y.B. U.N. L. 237, 256-59 (2004) (critiquing the Bush Doctrine for preemptive selfdefense); Cohan, supra note 17, at 328-37; Arimatsu \& Schmitt, supra note 17, at 16-19.

20. Military and Paramilitary Activities in and Against Nicaragua (Nicar. v. U.S.), Judgement, 1986 I.C.J. 14, ๆ 195 (June 27) ("[I]r is the State which is the victim of an armed attack which must form and declare the view that it has been so attacked.").

21. U.N. Charter art. 39.

22. Id. art. 25; see also id. art. 48 ("The action required to carry out the decisions of the Security Council for the maintenance of international peace and security shall be taken by all the Members of the United Nations or by some of them, as the Security Council may determine.").

23. See Nicholas Rostow, Determining the Lawfulness of the 2003 Campaign against Iraq, 34 Isr. Y.B. Hum. Rts. 15 (2004) (analyzing the debate abour the ambiguity of the duration and enforcement of Security Council resolutions about Iraq); Ian Hurd, The UN Security Council and the International Rule of Law, 7 Chinese J. INT'L Pol. 361, 363-65 (2014) (discussing the powers of the Security Council); Niels Blokker, Outsourcing the Use of Force: Tousards More Security Council Control of Authorized Actions?, in THE Oxford HaNdBooK of the Use of Force in International Law 202, 207 (Marc Weller ed., 2015) (discussing eighty Security Council resolutions adopted between 2000 and 2012 to establish or continue operations authorized to use military force).

24. U.N. Charter art. 42.

25. Id. arts. 43, 47. 
for member states to contribute the necessary elements and services ad boc, or for the Security Council to designate a leading state to recruit participants and manage the operations. ${ }^{26}$

In addition to these two main bases for the use of force, there are some additional shards of international law that might be relevant in particular instances. The UN General Assembly has occasionally led the international use of force under the "Uniting for Peace" Resolution when the Security Council has been deadlocked ${ }^{27}$; a "regional arrangement," acting pursuant to Chapter VIII of the Charter, can play a special role as an agent of the Security Council (or more than that) ) $^{28}$ and the doctrines of "countermeasures" and "belligerent reprisal" may retain some contested validity. ${ }^{29}$ Moreover, as discussed further infra, states and commentators have occasionally argued in support of a use of force alleged to be "illegal but legitimate," as where the constraints of the Charter do not truly justify the military campaign but some participants or observers (e.g., the states sponsoring the attack) nonetheless consider it morally or otherwise justified. ${ }^{30}$

But the main outlines of contemporary jus ad bellum are clear: unless there is a Security Council resolution, surviving the gauntlet of the P5 veto, or a genuine self-defense rationale, based on necessity and proportionality, then the use of force is presumptively illegal. This highly restrictive stance on initiating warfare is hardly accidental. In the aftermath of World War II,

26. Id. arts. 48, 49; see Mohamed S. Helal, Justifying War and the Limits of Humanitarianism, 37 Fordham INT'L L.J. 551, 600 (2014) [hereinafter Helal, Justifying War] (discussing the practical operation of U.N. peacekeeping forces); Allain, supra note 19, at 244-45; Hurd, supra note 23, at 3; Blokker, supra note 23.

27. See, e.g., G.A. Res. 377 (V), United for Peace (Nov. 3, 1950); Andrew J. Carswell, Unblocking the UN Security Council: The Uniting for Peace Rerolution, 18 J. Conflict \& Sec. L. 453 (2013); Thomas M. Franck, Recourse to Force: State Action against Threats and Armed Attacks 24-40 (2002); Nigel D. White, The Relationship Between the UN Security Conncil and General Assembly in Matters of International Peace and Security, in THE OXFORd HANDBOoK OF THE USE OF ForCE IN INTERNATIONAL LAw 293, 308-13 (Marc Weller ed., 2015).

28. U.N. Charter arts. 52-54. Under the Charter's original Chapter VII concept, a regional organization would need authorization from the Security Council prior to a use of military force; in practice, regional organizations have sometimes acted first, and sought Security Council endorsement afterward, and sometimes, the putative "authorization" has been in the form of the Security Council's failure to adopt a resolution condemning the activity (even if that failure was due to an exercise of the veto power). See Franck, Who Killed, supra note 17, at 822-26; Wippman, Nine Lives, supra note 17, at 401-03; Peter E. Harrell, Modern-Day "Guarantee Clanses" and the Legal Autbority of Multinational Organizations to Awthorize the Use of Military Force, 33 YALE J. INT'L L. 417, 420-23 (2008); Erika De Wet, Regional Organizations and Arrangements: Autborization, Ratification, or Independent Action, in THE OXFORD Handbook of the USE of Force in International Law 314 (Marc Weller ed., 2015); Allain, supra note 19, at 248-51; David Wippman, Military Intervention, Regional Organizations, and Host-State Consent, 7 Duke J. CoMp. \& INT'L L. 209, 228 (1996) [hereinafter Wippman, Military Intervention] (suggesting that a regional organization should have "a substantial margin of appreciation" in making judgments about the need for military intervention).

29. The doctrine of countermeasures allows a country to undertake an action that would ordinarily be illegal, but is justified as part of an effort to induce some other state to reverse its own prior illegal action. Belligerent reprisal is a type of countermeasure involving the use of armed force, now generally deemed illegal under the Charter. See Int'l L. Comm'n, Draft Articles, supra note 16, at 75-76, 128-39; Henkin, Gross Violation, supra note 12.

30. See infra text accompanying notes $85-86$. 
the planet's most devastating human-caused apocalypse, the states were united in making their top priority "to save succeeding generations from the scourge of war." ${ }^{31}$ The animating thrust of the new law was to make it harder for states to resort to battle; the paramount goal was to avoid another catastrophic conflict at (almost) any cost.

Operational Experience. Unfortunately, the resulting structures have proven inadequate, or unrealistic. The Security Council may reach its momentous decisions only pursuant to $\mathrm{P} 5$ unanimity; ${ }^{32}$ the veto power enables each of them to block a military campaign that it perceives as being adverse to its interests, and each P5 member has done so. ${ }^{33}$ The Charter therefore overdeters or over-impedes the application of force; a cynical, excessive, or narrow-minded use or threat of the veto can disempower a legal military response, even if the vast majority of the world community deems it appropriate and necessary. ${ }^{34}$

Just as bad, the institution of the veto has spawned a profound disrespect, in practice, for the Charter's standards. Countries have, in fact, resorted to the international use of force on scores of occasions, even in the absence of a Security Council authorization or a colorable self-defense claim.

31. U.N. Charter pmbl.; see also id. art. 1, I 1; Gabriella Blum \& John C.P. Goldberg, War for the Wrong Reasons: Lessons from Law, 11 J. Moral PHIL. 454, 475 (2014) (citing the Charter's preference for peace and security over justice and change).

32. U.N. Charter art. 27, \ 3 . On its face, this provision requires the "affirmative vote" of each of the P5 for the Security Council to make a decision; in practice, a permanent member may "abstain" without vetoing a resolution. Allain, supra note 19, at 241; see also Mohamed S. Helal, AmI My Brotber's Keeper? The Reality, Tragedy, and Failure of Collective Security, 6 HARv. NAT'L SEC. J. 383, 416-17, 427-33 (2015) [hereinafter Helal, Brother's Keeper] (noting that despite many states' resistance to the veto power, none of the P5 would have joined the Charter without that special perquisite); Richard Burler, Reform of the United Nations Security Council, 1 PenN. St. J.L. \& INT'L Aff. 1, 28-29 (2012).

33. See Security Council - Veto List, United Nations, Dag Hammarskjold Library, Research Guides (Jan. 12, 2016), http://research.un.org/en/docs/sc/quick [https://perma.cc/5CPA-MNEU]; Philippa Webb, Deadlock or Restraint? The Security Council Veto and the Use of Force in Syria, $10 \mathrm{~J}$. Conflict \& SEC. L. 471, 473-76 (2014) (summarizing PS practice in casting veroes).

34. See Strengthening the United Nations, THE ElDERs (Feb. 7, 2015), http://theelders.org/sites/default/files/2015-04-22_elders-statement-strengthening-the-un.pdf [https://perma.cc/XJP6-DBPY] (proposing reform of the veto process, through which the P5 would pledge not to use or threaten the veto simply to protect their own national interests); Butler, supra note 32, ac 30 (emphasizing how the mere threat of the veto, in addition to its exercise, can paralyze the Security Council); see also Helal, Brotber's Keeper, supra note 32 (arguing that the Security Council was not truly intended to serve a global collecrive security function, but to preserve peaceful relations among the great powers); Lori Fisler Damrosch, Introdiction, in Enforcing Restraint: Collective Intervention in INTernal. Crises l, 12 (Lori Fisler Damrosch ed., 1993) (asserting that "large segments of the international community have been willing to endorse strong collective action in a wide range of situations" including prevention of genocide, enabling the delivery of humanitarian relief, enforcing cease-fire agreements, and restoring civil order); Amnesty Calls on UN Powers to Lose Veto on Genocide Votes, BBC NEws (Feb. 25, 2015), hetp:// www.bbc.com/news/world-31617141 [https://perma.cc/CV8A-ESLQ]; Somini Sengupta, France Asks Veto Wielders to Stay Their Hands, N.Y. TIMEs (Sept. 25, 2014), http://www.nyrimes.com/news/un-general-assembly/2014/09/25/france-asks-veto-wielders-to-stay-their-hands/ [https://perma.cc/M42NHNVH\}; Paolo Bargiacchi, Strengtbening the Rule of Law as a Means of Reforming the UN Security Council, in Democracy at the United Nations: UN Reform in the Age of Globalism 275 (Giovanni Finizio \& Ernesto Gallo eds., 2013). But see Crispin Tickell, The Role of the Security Council in World Affairs, 18 GA. J. INT'L \& Comp. L. 307, 312 (1988) (defending the veto power as "vital"). 
By one count, there were no fewer than 200 "illegal" wars between 1945 and 1989; another survey tallied 690. ${ }^{35}$ Professors Thomas M. Franck ${ }^{36}$ (in the 1970s) and Michael J. Glennon ${ }^{37}$ (in the 2000s) have concluded that Article 2(4) is thereby "dead," defunct, or obsolete-they argue that it no longer serves as an accurate reflection of what states believe the applicable international law is or should be. ${ }^{38}$

All of this eccentric behavior is compounded by the anachronistic composition of the Security Council. The P5 were the leading survivors of World War II, but the global balance of power has conspicuously shifted since 1945. These states are surely still of utmost importance today, but other emergent actors matter too, and they are not adequately reflected in the inner councils of the United Nations. The restricted permanent membership and the exclusive veto power seem increasingly anomalous today, and the global democracy deficit undermines the legitimacy of Security Council actions (and inactions). But any proposal to alter the composition of the Security Council, to make it more broadly representative of contemporary geopolitical realities, is itself subject to the veto, so sequential reform efforts have been stillborn. ${ }^{39}$

35. High-Level Panel, supra note 19, at $140 \mathrm{n} .104$; see also Armed Conflict Data Base Index, INT'L INST. For Strategic STud., hetps://acd.iiss.org/en/acdindex (last visited Feb. 24, 2016) [htrps://perma .cc/G8LV-RE7D] (reporting 42 active conflicts in 2014); David A. Backer \& Paul K. Huth, Global Trends in Amed Conflict: 1946-2012, in PeACE AND Conflict 201418 (David A. Backer, Jonathan Wilkenfeld, \& Paul K. Huth eds., 2014); Lotta Themner \& Peter Wallensteen, Patterns of Organized Violence 2003-12, in SIPRI Yearbook: Armaments, Disarmament, and International Security 70 (2014) (identifying seventy-six state-based conflicts between 2003 and 2012, including thirty-two in 2014, and approximately four to six such conflicts each year were intense enough to be labeled "war"); Bruno Tertrais, The Demise of Ares: the End of War as We Know It?, 35 WASH. Q., Summer 2012, at 7; Nat'l Intelligence Counc., Global Trends 2030: Alternative Worlos 59 (noting fewer interstate, and more intrastate, wars).

36. See Franck, Wbo Killed, supra note 17, at 810-11 (citing 100 interstate wars between 1945 and 1970, only one of which provoked the Security Council to act). But see Louis Henkin, The Reports of the Death of Article 2(4) Are Greatly Exaggerated, 65 AM. J. INT'L L. 544 (1971) thereafter Henkin, Reports of the Death]; Wippman, Nine Lives, supra note 17, ac 387-91.

37. See Michael J. Glennon, Why the Security Cortncil Failed, 82 Foreign Aff. 16, 22 (2003) (arguing that so many states have used force on so many occasions in flagrant violation of the Charter that the regime can only be said to have collapsed); Michael J. Glennon, The Rise and Fall of the U.N. Charter's Use of Force Rules, 27 Hastings INT'L \& COMP. L. Rev. 497, 507 (2004) (citing 200 uses of force, which have reduced the Charter to mere "paper rules"); Michael J. Glennon, How International Rules Die, 93 GEO. L.J. 939 (2005) (asserting that non-enforcement and noncompliance with the rules limiting states' uses of military force have resulted in their abandonment via desuetude); Michael J. Glennon, The Limitations of Traditional Rules and Institutions Relating to the Use of Force, in THE OXFORD HANDBOOK OF the USE of Force in International Law 79, 90-95. (Marc Weller ed., 2015).

38. See Reisman, Coercion and Self-Determination: Constring Cbarter Article 2(4), supra note 11 (arguing that a state should be legally empowered to overthrow a despotic regime in another state); Michael Byers \& Simon Chesterman, "You, the People": Pro-Democratic Intervention in International Law, in DemoCratic Governance and International Law 259, 261-62 (Gregory H. Fox \& Brad R. Roth eds., 2000); James Crawford \& Rowan Nicholson, The Continued Relevance of Establisbed Rules and Institutions Relating to the $U_{\text {se }}$ of Force, in THE OXFORd HaNdBOOK OF THE USE OF Force IN INTERNATIONAL LAW 96 (Marc Weller ed., 2015).

39. See The Elders, supra note 34 (proposing to add a new category of Security Council permanent members who would not have the veto power, but who would increase the diversity of voices heard and provide better representation for different parts of the world); U.N. Secretary-General, In Larger Freedom; 
Nonetheless, the black-letter jus ad bellum remains: force is illegal unless one of the two justifications-self-defense or Security Council authorization-prevails. The Charter is almost amendment-proof (because the veto power applies to any proposed change ${ }^{40}$ ) so, for the foreseeable future, states and other players have to accept as given these fundamentals of the international law regarding military activity.

\section{Part II: Enforcement of International Human Rights}

The flowering of international legal respect for individual human rights is one of the most dramatic success stories of the post-World War II era. ${ }^{41} \mathrm{~A}$ skein of general-purpose global and regional human rights treaties has emerged, ${ }^{42}$ and specially-focused instruments, sequentially addressing scourges such as racism, gender discrimination, child abuse, discrimination

Towards Development, Security, and Human Rights for All, at 42-43, U.N. Doc. A/59/2005 (Mar. 21, 2005) [hereinafter Larger Freedom]; U.N. Secretary-General, Implementing the Responsibility to Protect, U.N. Doc. A/63/677 (Jan. 12, 2009) (proposing alcernative models for expansion of Security Council); THE INDEP. INT'L Comm'n ON Kosovo, The Kosovo RePORT 195-98 (2000), http://reliefweb.int/sites/reliefweb.int/files/resources/6D26FF88119644CFC1256989005CD392-thekosovoreport.pdf [https:/per ma.cc/AY3P-R7JC] [hereinafter Kosovo REPORT] (suggesting revisions to the Charter to make it more responsive to the need to protect human rights); Luisa Blanchfieid, Cong. ReSEarch Serv., United Nations Reform: Background and Issues for Congress (2015); Butler, supra note 32; Helal, Brotber's Keeper, supra note 32, at 388; Jean Galbraith, The Security Council Resolution on the Iran Deal-A Way around the Reverse Veto, OpINIO JuRIS (July 23, 2015), http://opiniojuris.org/2015/07/23/guest-postthe-security-council-resolution-on-the-iran-deal-a-way-around-the-reverse-veto/ [https://perma.cc/ R69W-VSLX] (considering possible wording of Security Council resolutions that could make their extension or termination easier).

40. U.N. Charter art. 108. The Charter has been amended only a few times, mostly to enlarge the size of UN organs to take into account the larger number of member states. See, e.g., G.A. Res. 1991 (XVIII) (Dec. 17, 1963) (enlarging the Security Council from eleven to fifteen members).

41. Hargrove, supra note 12, at 113; Helal, Brother's Keeper, supra note 32, at 390-92, 436-48 (discussing the "humanization of security," with international protection of fundamental human rights playing a larger role in Unired Nations affairs); Gareth Evans, The Responsibility to Protect: An Idea Whose Time Has Come ... and Gone?, 22 INT'L ReL. 283, 284 (2008) (arguing that "for an insanely long time" state sovereignty had been considered absolute, but the emergence of concern for human rights after World War II changed that perspective); Gino J. Naldi \& Kostantinos D. Magliveras, Human Rights and the Denunciation of Treaties and Witbdrawal from International Organizations, 33 POLISH Y.B. INT'L L. 95, 96 (2013) ("[T]he international protection of human rights is primarily a post-World War II development."); W. Michael Reisman, Sovereignty and Human Rights in Contemporary International Law, in Democratic Governance and International Law 239, 250 (Gregory H. Fox \& Brad R. Roth eds., 2000).

42. See U.N. Charter arts. 55, 56; Universal Declaration of Human Rights, G.A. Res. 217 (III) (Dec. 10, 1948); International Covenant on Civil and Political Rights, Dec. 16, 1966, 999 U.N.T.S. 171, 6 I.L.M. 368 thereinafter ICCPR]; International Covenant on Economic, Social and Cultural Rights, Dec. 16, 1966, 993 U.N.T.S. 3 [hereinafter ICESCR]; European Convention for the Protection of Human Rights and Fundamental Freedoms, Nov. 4, 1950, 312 U.N.T.S. 221; American Convention on Human Rights, Nov. 22, 1969, 9 I.L.M. 673; African Charter on Human and Peoples' Rights, June 27, 1981, 21 I.L.M. 59; see also Conntry Reports on Human Rights Practices for 2014: Appendix D: Description of International Human Rights Conventions in Appendix C, U.S. Dep'T OF STATE, http://www.state.gov/

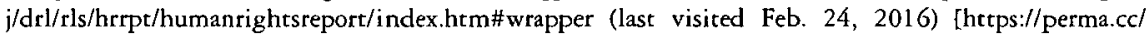
R7HY-SS37] [hereinafter DeP'T OF STATE, Country Reports] (listing international human rights conventions). 
against the disabled, and more have likewise proliferated. ${ }^{43}$ Many of these canonical accords have attracted widespread adherence, although the United States has refrained from joining several ${ }^{44}$ and many are burdened by numerous restrictive reservations. ${ }^{45}$ Several of the treaties have evoked their own standing implementation bodies or courts. ${ }^{46}$ This new tapestry of jurisprudence reinforces the message that the traditional remit of international law-accustomed to focusing almost exclusively upon state-to-state relationships-is now enriched by a revolutionary recognition of individual human beings as accountable players with their own direct rights and responsibilities in the international legal system.

The primary focus here is on a subset of these human rights instruments: those that specifically address the worst atrocities of human behavior, such as the 1948 Genocide Convention, ${ }^{47}$ the 1984 Convention against Torture, ${ }^{48}$ the 1949 and 1977 Geneva Conventions and Protocols ${ }^{49}$ dealing

43. See International Convention on the Elimination of All Forms of Racial Discrimination, Jan. 7, 1966, 660 U.N.T.S. 195, 5 I.L.M. 352; Convention on the Elimination of All Forms of Discrimination Against Women, Dec. 18, 1979, 1249 U.N.T.S. 13; Convention on the Rights of the Child, Nov. 20, 1989, 1577 U.N.T.S. 3; Convention on the Rights of Persons with Disabilities, G.A. Res. $61 / 106$ (Jan. 24, 2007); see also International Convention on the Protection of the Rights of All Migrant Workers and Members of Their Families, Dec. 18, 1990, 2220 U.N.T.S. 3; Convention Concerning Indigenous and Tribal Peoples in Independent Countries, June 27, 1989, 28 I.L.M. 1382; Convention Relating to the Status of Refugees, July 28, 1951,189 U.N.T.S. 137; Universal Human Rights Instruments, THE OFFICE OF THE U.N. HIGH COMM'r FOR HUMAN RIGHTS, http://www.ohchr.org/EN/ProfessionalInterest/ Pages/UniversalHumanRightsInstruments.aspx (last visited Feb. 24, 2016) [https://perma.cc/UM3Y839T] (listing "Universal Human Rights Instruments").

44. Among others, the United States has not ratified the International Convention on Economic, Social and Cultural Rights, the Convention on Discrimination Against Women, the Convention on the Rights of the Child, and the Convention on Disabilities. See supra nore 43; Status of Ratification of Human Rights Instruments, The Office of the U.N. High Comm'r for Human Rights (Feb. 2, 2013), www .ohchr.org/Documents/HRBodies/HRChart.xls [https://perma.cc/K4CF-W42K].

45. Many human rights treaties have been subject to extensive reservations, declarations, and orher conditions. See Cbapter IV: Human Rights, UnITED NAtıons, https:/treaties.un.org/Pages/Treaties.aspx? id=4\&subid=A\&lang=en (last visited Feb. 29, 2016) [https://perma.cc/DS9K-5TAC].

46. See The Core International Human Rights Instmoments and Their Monitoring Bodies, THE OFFICE OF THE U.N. High Comm'r FOR Human Rights, http:/www.ohchr.org/EN/ProfessionalInterest/Pages/ CoreInstruments.aspx (last visited Feb. 29, 2016); Monitoring the Core International Human Rights Treaties, The Office of THE U.N. High COMm'R fOR Human RIGHTS, http:/www.ohchr.org/EN/HRBodies/ Pages/TreatyBodies.aspx [https:/perma.cc/N2RJ-78YY] (observing that each of the ten core human rights instruments establishes its own committee of experts to monitor implementation of treaty provisions).

47. Genocide Convention, supra note 4. The Genocide Convention prohibits actions "committed with intent to destroy, in whole or in part, a national, ethnical, racial or religious group, as such." Id. art. II. It has 146 parties. Genocide Convention, stupra note 4.

48. Convention Against Torture and Other Cruel, Inhuman, or Degrading Treatment or Punishment, Dec. 10, 1984, 1465 U.N.T.S. 85 [hereinafter Convention Against Torture]. The Convention Against Torture prohibits intentional infliction of severe pain or suffering for purposes such as punishing, intimidacing, or coercing a person, or forcing him or her to provide information or a confession. Id. art. 1. It has 158 parties. Id.

49. Convention for the Amelioration of the Condition of the Wounded and Sick in Armed Forces in the Field, Aug. 12, 1949, 6 U.S.T. 3114, 75 U.N.T.S. 31; Convention for the Amelioration of the Condition of the Wounded, Sick and Shipwrecked Members of the Armed Forces at Sea, Aug. 12, 1949, 6 U.S.T. 3217, 75 U.N.T.S. 85; Convention Relative to the Treatment of Prisoners of War, Aug. 12, 1949, 6 U.S.T. 3316, 75 U.N.T.S. 135; Convention Relative to the Protection of Civilian Persons in 
with war crimes, and the 1988 Rome Statute establishing the International Criminal Court. ${ }^{50}$ These types of offenses, collectively denominated as "the most serious crimes of concern to the international community as a whole," ${ }^{51}$ have animated universal condemnation and have at least occasionally driven states to undertake vigorous collective remedial and preventative measures.

Numerous types of mechanisms may be helpful in promoting compliance with these human rights treaties and combating impunity for the perpetrators of atrocities. ${ }^{52}$ Public pressure, increasingly mobilized by non-governmental organizations and social media, plays a role, ${ }^{53}$ as does peer pressure, which states exert in various UN fora and through other traditional diplomatic avenues. ${ }^{54}$ The United Nations Human Rights Council endeavors to hold states accountable, by requiring public display and critique of their human rights practices, such as via the Universal Periodic Review process. ${ }^{55}$

Time of War, Aug. 12, 1949, 6 U.S.T. 3516, 75 U.N.T.S. 287; Protocol Additional to the Geneva Conventions of 12 August 1949, and Relating to the Protection of Victims of International Armed Conflicts (Protocol I), June 8, 1977, 1125 U.N.T.S. 3; Protocol Additional to the Geneva Conventions of 12 August 1949, and Relating to the Protection of Victims of Non-International Armed Conflicts (Protocol II), June 8, 1977, 1125 U.N.T.S. 609. These treaties provide the basic international standards for humane treatment of the victims of international and non-international armed conflict, such as the wounded and sick, prisoners of war, and civilians, and it also establishes war crimes offenses.

50. Rome Statute of the International Criminal Court, July 17, 1998, 2187 U.N.T.S. 3 [hereinafter Rome Statute]; see also Slavery Convention, Mar. 8, 1929, 46 Stat. 2183, 182 U.N.T.S. 51; International Convention on the Suppression and Punishment of the Crime of Apartheid, Nov. 30, 1973, 1015 U.N.T.S. 243. There is no separate treaty dedicated to the problem of "crimes against humanity." Many of these atrocities would be covered by other agreements, but the International Law Commission has explored the concept of a new instrument on this topic. See Special Rapporteur on Crimes against Humanity, First Report of the Special Rapporteter on Crimes against Humanity, Int'l L. Comm'n, U.N. Doc A/CN.4/680 (Feb. 17, 2015) (by Sean D. Murphy).

51. See Rome Statute, supra note 50, art. 5.1.

52. See Sarah Sewall, Under Secretary of State for Civilian Security, Democracy, and Human Rights, U.S. Dep't of State, Making Progress: US Prevention of Mass Atrocities (April 24, 2015), http://www .state.gov/j/remarks/241222.htm [htrps://perma.cc/NK4Z-P76X] (underscoring announcement by President Obama that prevention of mass atrocities is a core national security and moral responsibility, and describing organizations within the Department of State and with interagency partners to mitigate them); Marko Milanovic, Enforcement of Human Rights, Oxford Biblographies (June 25, 2013), http:// www.oxfordbibliographies.com/view/document/obo-9780199796953/obo-9780199796953-

0062.xml\#obo-9780199796953-0062-div1-0004 [https://perma.cc/KF3J-6V3P].

53. See, e.g., Exposing and Preventing Human Rights Abuses, AMNESTY INT'L, http://www.amnestyusa .org/our-work (last visited Feb. 24, 2016) [hteps://perma.cc/2VNK-N8LC]; What We Do, INT'L Comm. OF THE RED CROSs, https://www.ictc.org/en/what-we-do (last visited Feb. 24, 2016) [https://perma.cc/ RJ2L-9WZD].

54. See Protect Human Rights, UNITEd NATIONs, http:/www.un.org/en/sections/what-we-do/protecthuman-rights/index.html (last visited Mar. 5, 2016) [https:/perma.cc/LFZ2-7DKC]; Mission Statement, Office of THE Special Adviser on THe Prevention of Genocide, hetp://www.un.org/en/preventgenocide/adviser/ (last visited Mar. 5, 2016) [https:/perma.cc/JD3H-6L2M] (noting activities of UN Special Advisers on the Prevention of Genocide and on the Responsibility to Protect).

55. See United Nations Human Rights Conncil, The Office of the U.N. High Comm'r for Human RIGHTS, http://www.ohchr.org/en/hrbodies/hrc/pages/hrcindex.aspx (last visited Feb. 29, 2016) [https:// perma.cc/8R8C-DT4B]. The Universal Periodic Review is a process, initiated in 2006, for regular selfreporting and review of the human rights practices of each UN member state. See Universal Periodic Review, The Office of the U.N. High Comm'r for Human Rights, http:/www.ohchr.org/EN/ HRBodies/UPR/Pages/UPRMain.aspx (last visited Feb. 29, 2016) [https://perma.cc/9SVS-AECW]. 
As noted, many of the human rights treaties have created specialized enforcement mechanisms, such as the Human Rights Committee (which promotes the 1966 International Covenant on Civil and Political Rights (ICCPR) $)^{56}$ and the Committee Against Torture (which monitors compliance with the Convention Against Torture). ${ }^{57}$ In addition, regional treaties and arrangements ${ }^{58}$ and specialized human rights courts ${ }^{59}$ have proliferated and have been accorded special weight in overseeing members' behavior.

Tragically, these diverse enforcement tools, for all their value, fail far too often; the roll call of atrocities around the world seems unending. The horrors in Rwanda, Bosnia, Cambodia, Kosovo, Darfur, Congo, Libya, Syria, North Korea and elsewhere serve as shocking reminders of the repeated failures of the world's system for adequately protecting even the most basic human rights. ${ }^{60}$

In this environment, the traditional legal responses to a violation of a treaty seem particularly fatuous. Under the 1969 Vienna Convention on the Law of Treaties (VCLT), the "remedies" available to states aggrieved by

56. See Human Rights Committee, The Office of THE U.N. High Comm'r for Human Rights, http://www.ohchr.org/EN/HRBodies/CCPR/Pages/CCPRIntro.aspx (last visited Feb. 29, 2016) [https:/ /perma.cc/2N4E-QV25].

57. See Committee Against Torture, The Office of the U.N. High Comm'r for Human Rights, http://www.ohchr.org/EN/HRBodies/CAT/Pages/CATIntro.aspx (last visited Feb. 29, 2016) [https://per ma.cc/Z4MW-CLPD]; Time for States to Make 30-Year-Old Treaty a Reality, UNITED Nations Comm. AGainst Torture (Oct. 22, 2014), http:/www.ohchr.org/EN/NewsEvents/Pages/DisplayNews.aspx? NewsID $=15194 \&$ LangID $=\mathrm{E}$ [https:/perma.cc/CK7U-BW28] (noting the commitree's annual report to the General Assembly and its global initiative for universal racification and implementation of the convention).

58. See, e.g., European Convention for the Protection Human Rights and Fundamental Freedoms, supra note 42; American Convention on Human Rights, stpra note 42; African Charter on Human and Peoples' Rights, supra note 42.

59. Such as the European Court of Human Rights, the African Court on Human and Peoples' Rights, and the Inter-American Commission on Human Rights. The International Criminal Court is also relevant to this analysis, both for attempting to end impunity for mass atrocity crimes and more recently for bringing the crime of aggression within the active jurisdiction of the court. See Sarah Sewall, Under Secretary of State for Civilian Security, Democracy, and Human Rights, U.S. Dep't of State, The ICC Crime of Aggression and the Changing International Security Landscape (April 9, 2015), http:// www.state.gov/j/remarks/240579.htm [https:/perma.cc/VS6R-AJQT]; Harold Hongju Koh \& Todd F. Buchwald, The Crime of Aggression: The United States Perspective, 109 AM. J. INT'L L. 257 (2015).

60. See DeP't of State, Country Reports, sipra note 42; R2P Monitor, Glob. CTr. for the Resp. To Protect, http://www.globalr2p.org/our_work/r2p_monitor (last visited Feb. 29, 2016) [https://perma .cc/AWE5-KQNQ] (surveying ongoing human rights crises in several countries); Manuel Ortega, Why Should Humanitarian NGOs Avoid Calling for Military Interventions?, FONDATION POUR LA RECHERCHE Strategreue, March 16, 2015, at 6 (asserting that 21 areas might currently fall under R2P auspices); Ben Kioko, The Right of Intervention Under the African Union's Constitutive Act: From Non-Interference to Non-Intervention, 85 INT'L Rev. Red CROSS 807, 818 (2003) (observing that humanitarian intervention has been controversial both when it occurs and when it does not); Enforcing Restraint: Collective Inter vention in Internal Conflicts (Lori Fisler Damrosch ed., 1993) (presenting several case studies of intervention designed to arrest serious human rights violations). The Carnegie Commission on Preventing Deadly Conflict concluded that the world spent $\$ 200$ billion on conflict management in seven major interventions in the 1990s (including Bosnia, Somalia, Rwanda, Haiti, the Persian Gulf, Cambodia and El Salvador). See Int'l Comm'n on Intervention and State Sovereignty, The ReSPONSIBILITY to Protect 20 (2001), hetp://responsibilitytoprotect.org/ICISS\%20Report.pdf [htrps:// perma.cc/K72F-7YT3] [hereinafter ICISS REPORT] 
another party's material breach feature the right to suspend or terminate the operation of the treaty, in whole or in part. ${ }^{61}$ But that power is inapplicable to treaty provisions "relating to the protection of the human person contained in treaties of a humanitarian character." 62 Even when available, this "suspend or terminate" recourse leads only to a further unraveling of the treaty, not to its restoration and the vindication of the human rights at stake. In this context, interrupting the counter-performance by the innocent states, and withdrawing their own reciprocal protection for the human rights of additional groups of people, would be unlikely to pressure the violator to return to compliance and would only compound the problem.

Human rights treaties demonstrate widely varying patterns regarding other aspects of durability or escape. Some treaties explicitly allow withdrawal or denunciation, but exercise of that option has been quite rare. ${ }^{63}$ Conversely, some leading instruments do not incorporate withdrawal or termination clauses. For example, the ICCPR ${ }^{64}$ and the companion 1966 International Covenant on Economic, Social and Cultural Rights (ICESCR) ${ }^{65}$ — key elements in the "international bill of rights" 66 - have no provisions on duration or exit. The Human Rights Committee, the body charged with monitoring and implementation of the ICCPR, has authoritatively determined that the treaty is a one-way street, disallowing any party's withdrawal. ${ }^{67}$ Relatedly, some human rights treaties allow a party to tem-

61. Vienna Convention on the Law of Treaties, art. 60, May 23, 1969, 1155 U.N.T.S. 331, 8 I.L.M. 679 [hereinafter VCLT]; see Bruno Simma \& Christina J. Tams, Treaty Breach, in THE OXford Guide to Treaties 576 (Duncan B. Hollis ed., 2012).

62. VCLT, supra note 61, art. 60.5; see Restatement of the Foreign Relations Law of the United States $\$ 332$ (1986) [hereinafter Restatement]; Yogesh Tyagi, The Denunciation of Human Rights Treaties, 79 British Y.B. INT'L L. 86, 103, 105 (2009).

63. Tyagi, supra note 62 , at 181-82 (finding only five true cases of denunciation of human rights treaties, amounting to less than two percent of the total number of ratifications and accessions of the targeted instruments); Naldi \& Magliveras, supra note 41.

64. ICCPR, supra note 42.

65. ICESCR, supra note 42.

66. The International Bill of Rights consists of the Universal Declaration of Human Rights, the ICCPR, and the ICESCR. See Fact Sheet No. 2 (Rev. 1), The International Bill of Human Rigbts, THE OfFice OF THE U.N. High COMm'R FOR Human Rights (Dec. 10, 1948), http://www.ohchr.org/Documents/Publications/FactSheet2Rev.1 en.pdf [https://perma.cc/EQ25-8RLH].

67. Human Rights Comm., General Comments Adopred by the Human Rights Commitree Under Article 40, Paragraph 4, of the International Covenant on Civil and Political Rights, U.N. Doc. CCPR/ C/Rev.1/Add.8/Rev.1 (Dec. 8, 1997), http://www.ccprcentre.org/doc/ICCPR/General\%20Comments/ CCPR.C.21.Rev1.Add8.Rev1_(GC26)_En.pdf [https://perma.cc/8YAF-5B8B] (body charged with implementing the ICCPR concludes that "international law does not permit a State which has ratified or acceded to the Covenant to denounce it or withdraw from it"); see also Oona A. Hathaway, International Delegation and State Sovereignty, 71 Law Contemp. Probs. 115, 131 (2008) [hereinafter Hathaway, International Delegation] (observing that most treaties, including human rights treaties, allow some form of unilateral withdrawal or exit, but the Charter has no such provision and may be regarded as irrevocable); Tyagi, supra note 62, at 124-29 (surveying the denunciation provisions of several human rights treaties); Tyagi supra note 62, at 138 (noting that no other treaty implementation body has adopted a statement opposing denunciation similar to that of the Human Rights Committee regarding the ICCPR); Naldi \& Magliveras, supra nore 41, at 111-12 (listing human rights treaties containing no denunciation clause). 
porarily suspend or derogate from selected provisions in exceptional cases of national emergency. ${ }^{68}$ But others, such as the Convention Against Torture, expressly disallow even a temporary sabbatical from the obligations even in "exceptional circumstances." 69

The Concept of R2P. Within the last two decades, the concept of "responsibility to protect" (R2P) has emerged to help address these persistent shortcomings. ${ }^{70}$ Fueled by a newfound conviction that the perquisites of state sovereignty are not unlimited, and that "outsiders" have a legitimate stake in how a state treats its own nationals, $R 2 P$ rests upon three pillars. First is the proposition that each state has a responsibility, concomitant with its right to sovereignty, to protect its own population from the atrocities of war crimes, genocide, crimes against humanity, and ethnic cleansing. ${ }^{71}$ Second, the international community has a corresponding responsibility to assist states in fulfilling that obligation, via supportive monitoring, education, and capacity-building. ${ }^{72}$ Finally, if a state manifestly fails to protect its people from these atrocities, the international community has a responsibility to respond via coercive measures including economic sanctions and, as a last resort, military force..$^{73}$

68. See, e.g., ICCPR, supra note 42 , art. 4.1 (allowing derogation from some provisions of the treaty where "strictly required" by a public emergency); Emilie M. Hafner-Burton, Laurence R. Helfer \& Christopher J. Fariss, Emergency and Escape: Explaining Derogations from Human Rights Treaties, 65 INT'L OrG. 673 (2011) (studying 586 instances of derogation from three human rights treaties by thircy-three countries over the past half-century).

69. Convention Against Torture, supra note 48, art. 2.2.

70. Hathaway, Consent-Based, supra note 12, at 503; Brighton Haslett, No Responsibility for the Responsibility to Protect: How Powerful States Abuse the Doctrine, and Why Misuse Will Lead to Disuse, 40 N.C. J. INT'L L. \& COM. ReG. 171, 172 (2014); Edward Newman, R2P: Implications for World Order, 5 GioB. Resp. to Protect 235 (2013); Christopher C. Joyner, "The Responsibility to Protect": Humanitarian Concern and the Lawfulness of Amed Intervention, 47 VA. J. INT'L. L. 693, 704-705 (2007); Evans, supra note 41, at 284-90 (tracking the rise and fall of the concept of R2P); Monica Hakimi, Toward a Legal Theory on the Responsibility to Protect, 39 YAle J. IN'T'L L. 247 (2014); Margaret M. DeGuzman, When Are International Crimes Just Cause for War?, 55 VA. J. INT'L. L. 73 (2014); Saira Mohamed, Taking Stack of the Responsibility to Protect, 48 STAN. J. INT'L. L., 319, 319 (2012); Steven Groves, The U.S. Should Reject the U.N. "Responsibility to Protect" Doctrine, The Heritage Found., May 1, 2008; Sarah Sewall, Under Secrerary of State for Civilian Security, Democracy, and Human Rights, U.S. Dep't of State, Remarks on the 8th Annual Ministerial Meeting on Responsibility to Protect (R2P) (Sept. 30, 2015).

71. ICISS REPORT, supra note 60, at 19-27 (discussing the "commitment to prevention" and the "toolbox" of political, economic, legal, military and other measures to forestall atrocities). Note that the concept of "ethnic cleansing" is not as well defined as a separate international crime; it is not explicitly identified as a topic within the mandate of the International Criminal Court, and is not the subject of a separate treaty. But it is traditionally listed as one of the core areas of concern for R2P.

72. ICISS RePORT, supra note 60, at 29-37. These prevention efforts can encompass attention to both the "root causes" of conflict, such as poverty, and the "direct causes" that immediarely spark a conflict. Haslett, supra note 70 , at 182-83.

73. ICISS RePORT, supra note 60, at 29-37 (analyzing measures short of military acrion and presenting six criteria for military intervention); Clarifying the Third Pillar of the Responsibility to Protect: Timely and Decisive Response, Int'l CoAltTION fOr Responsibllity to Protect, http://responsibilitytoprotect.org/Clarifying\%20the\%20Third\%20Pillar.pdf (last visited Mar. 1, 2016) [https://perma.cc/ 28PE-Q4MG]. The third pillar also includes a responsibility to help rebuild a state after an atrocity. See ICISS REPORT, supra note 60, at 39-45; Haslett, supra note 70, at 186-87.

The concept of R2P is related to a prior doctrine asserting that outside states might in some circumstances have a "right to undertake humanitarian intervention" when another state is violating the 
Inspired by a 2000 appeal by UN Secretary-General Kofi Annan ${ }^{74}$ and a 2001 report by the Canada-sponsored International Commission on Intervention and State Sovereignty, ${ }^{75}$ the concept of $\mathrm{R} 2 \mathrm{P}$ was endorsed by a broad collection of heads of state at the 2005 World Summit. ${ }^{76}$ Since then, the credo has assumed a life of its own, being reflected in numerous international, governmental, and scholarly assertions, as well as in General Assembly and Security Council resolutions. ${ }^{77}$

An important ambiguity, however, lingers at the core of R2P. In the standard articulation of the doctrine (what I call the "soft" version of R2P), the third pillar's ultimate invocation of military force to interdict an ongoing or pending atrocity could be legally justified only by a prior Chapter VII resolution adopted by the Security Council. ${ }^{78}$ It is thus consistent with

fundamental human rights of its citizens. The rhetorical transformation toward R2P is more than cosmetic; it reflects a refined understanding of state sovereignty, international responsibility, and the role of military compulsion. ICISS Report, supra note 60, at 8-9, 16-18; Henry J. Richardson III, Critical Perspectives on Intervention, 29 MD. J. INT't L. 12, 38 (2014); Hathaway, Consent-Based, supra note 12, at 522-27; Vladimir Kartashkin, Human Rights and Humanitarian Intervention, in LAW AND FORCE IN THE New International Order, 202, 204-06, (Lori Fisler Damrosch \& David J. Scheffer eds., 1991); Nigel Rodley, Humanitarian Intervention, in THE OXFORD HANDBOOK OF THE USE OF FORCE IN INTERNational Law 775 (Marc Weller ed., 2015); Murphy, Humanitarian Intervention, supra nore 15; Jean-Pierre $\mathbf{L}$. Fonteyne, The Customary International Law Doctrine of Humanitarian Intervention: Its Current Validity Under the U.N. Charter, 4 CAL. W. INT'L L.J. (1974) (surveying the precedents for humanitarian interventions); Ryan Goodman, Humanitarian Intervention and Pretexts for War, $100 \mathrm{AM}$. J. INT'L L. 107, $108-09,112$ (2006) (reporting vigorous debate about the legality of humanitarian intervention and noting that 133 states have issued public statements in opposition); Evans, supra note 41, at 290-91; Damrosch, ENForCING RestrainT, supra note 34 (presenting case studies in collective intervention); Thomas \& Thomas, supra note 14 , at $372-90$.

74. U.N. Secretary-General, We the Peoples: The Role of the United Nations in the 21st Century, at 47-48 (2000), http://www.un.org/en/events/pastevents/pdfs/We_The_Peoples.pdf [https://perma.cc/ J3ML-U5HL]; Press Release, U.N. Secretary-General, Secretary-General Presents His Annual Report to General Assembly, U.N. Doc. SG/SM/7136 (Sept. 20, 1999), http://www.un.org/press/en/1999/ 19990920.sgsm7136.html [https://perma.cc/T44YY-QSG3]

75. ICISS REPORT, supra note 60.

76. G.A., 2005 World Summit Outcome, at 138-39, U.N. Doc. A/60/L.1 (Sept. 15, 2001), http:// responsibilitytoprotect.org/world\%20summit\%20outcome\%20doc\%202005(1).pdf [https://perma.cc/ 7YSL-R43S] [hereinafrer World Summit].

77. Larger Freedom, supra note 39, at 35; U.N. Secretary-General, Implementing the Responsibility to Protect, U.N. Doc. A/63/677 (Jan. 12, 2009), http://www.un.org/en/ga/search/view_doc.asp?symbol=A/ 63/677 [https://perma.cc/7U38-W6UE]; Secretary-General, Responsibility to Protect: Timely and Decisive Response, Report of the Secretary-General, U.N. Doc. A/66/874-S/2012/578 (July 25, 2012); S.C. Res. 1674 (Apr. 28, 2006); G.A. Res. 60/1 (Sept. 16, 2005); G.A. Res. 63/308 (Oct. 7, 2009); High-Level Panel, supra note 19; Hathaway, Consent-Based, supra note 12, at 529-35 (noting that R2P is nor customary international law); Amir Seyedfarshi, French Interventionism in the Age of R2P: A Critical Examination of the Case of Mali, at 29-30 (Apr. 10, 2015) (unpublished manuscript), available at http://papers.ssrn.com/ sol3/papers.cfm?abstract_id=2592852 (reporting a debate about whether R2P is binding international law); Rosa Brooks, Lessons for International Law from the Arab Spring, 28 AM. U. INT'L L. REv. 713 , 719-24 (2013); Neomi Rao, The Choice to Protect: Retbinking Responsibility for Humanitarian Intervention, 44 Colum. Hum. Rrs. L. Rev. 697 (2013).

78. ICISS REPORT, supra note 60, at 47-55; World Summit, supra note 76, at 139 (expressing the global responsibility to protect populations by taking collective action "through the Security Council"); Hathaway, Consent-Based, supra note 12, at 532-34 (citing a "limited" version of R2P that requires Security Council assent for a use of force); Seyedfarshi, supra note 77 , at 24 (reporting some ambiguity about whether the doctrine of R2P allows independent use of military force by states without UN Security Council endorsement); Military and Paramilitary Activities in and Against Nicaragua (Nicar. 
standard jus ad bellum as discussed supra ${ }^{79}$-but it is correspondingly subject to blockage by the traditional P5 veto. Alternatively, a minority of $\mathrm{R} 2 \mathrm{P}$ advocates now advances a "hard" version, under which, if the Security Council is inextricably mired in P5 discord, a volunteer state or coalition could still undertake a military intervention. ${ }^{80}$ This more muscular interpretation of $\mathrm{R} 2 \mathrm{P}$ would presumably be operational more frequentlyavoiding the quagmire of US-Russian-Chinese geopolitics-but it does not conform to the dominant understanding of UN Charter rules about the use of force.

Experiences with R2P. Occasionally, the new R2P program has seemed to work more or less as anticipated. For example, in February 2011, the Security Council unanimously adopted a Chapter VII resolution deciding to authorize prompt, effective military action against Libya to prevent Muammar Gaddafi's threatened annihilation of political opposition elements in Benghazi-the first time the concept of $\mathrm{R} 2 \mathrm{P}$ had been so operationalized. ${ }^{81}$

v. U. S.), Judgement, 1986 I.C.J. 14, If 268 (June 27) (judging that the attempt to pursue human rights inside Nicaragua was not a sufficient justification for US intervention).

79. See supra text accompanying note 78; see also Hathaway, Consent-Based, supra note 12 , at 506-07 (noting that it is something of an advance simply for the Security Council to acknowledge that sometimes gross human rights violations can constitute a threat to the peace; this would not have been obvious in prior eras); Allain, supra note 19 , at 246-48.

80. Hathaway, Consent-Based, supra note 12, at 532-35 (discussing the "strong" version of R2P, which does not require Security Council approval for a use of force); U.K. Prime Minister's Office, Chemical Weapon Use by Syrian Regime: U.K. Government legal Posttion (August 29, 2013), https://www.gov.uk/government/uploads/system/uploads/arcachment_dara/file/235098/Chemical-

weapon-use-by-Syrian-regime-UK-government-legal-position.pdf [https://perma.cc/RPU9-GDDS] (asserting that even without a Security Council resolution, military intervention to alleviate the human rights catastrophe in Syria would be justified as an exceptional measure); Letter from the Rt. Hon. Hugh Robertson MP, U.K. Minister of State, Foreign and Commonwealth Office, to the Rr. Hon. Sir Richard Ottaway MP, U.K. House of Commons (Jan. 14, 2014), http://justsecurity.org/wp-content/ uploads/2014/01/Letter-from-UK-Foreign-Commonwealth-Office-to-the-House-of-Commons-ForeignAffairs-Committee-on-Humanitarian-Intervention-and-the-Responsibility-to-Protect.pdf [https://per ma.cc/3GD8-QX7Cl; Andrew M. Bell, Using Force Against the "Weapons of the Weak": Examining a Chemical-Biological Weapons Usage Criterion for Unilateral Humanitarian Intervention Under the Responsibility to Protect, 22 CARdozo J. INT'L Comp. L. 261, 282-89 (2014); Helal, Justifying War, supra note 26, at 625-26; Kress, supra note 11, at 24; Arimatsu \& Schmitt, supra note 17, at 25-26; SteVEN R. RATNER, The Thin Justice of International Law: A Moral Reckoning of the Law of Nations 293-96 (2015) (noting the "black-letter position" that humanitarian intervention wichout endorsement by the Security Council would be clearly unlawful, but numerous arguments can be made in favor of unauthorized humanitarian intervention); ICISS REPORT, supra note 60, at xiii (noting that if the Security Council "fails to discharge its responsibility to protect in conscience-shocking situations crying our for action, concerned states may not rule out other means to meet the graviry and urgency of that situation").

81. As Gaddafi's outrages became more apparent and rapacious, the UN Security Council responded intermittently by imposing economic sanctions and finally by authorizing military intervention to take all necessary measures to protect civilians under threat of attack. S.C. Res. 1973 (Mar. 17, 2011) (China, Russia, Germany, India, and Brazil abstaining). Some critics contend that the US-led military force then exceeded its mandare, going beyond protection of civilians, in order to effectuate "regime change," ousting Gaddafi. This perception has contributed to Russia and China, in particular, becoming less receptive to the whole concept of $\mathrm{R} 2 \mathrm{P}$ and unwilling to pursue similar remedies regarding the humanitarian crisis in Syria in 2011-15. Ortega, supra note 60, at 3; Helal, Brother's Keeper, supra note 32, at 464-66; David Rieff, R2P, R.I.P., N.Y. Times (Nov. 7, 2011), http://www.nytimes .com/2011/11/08/opinion/r2p-rip.html?_r=0 [https://perma.cc/5XB9-9MUS]; Lisa-Marie Komp, How 
However, what we observe more often on the international scene today are three deviant sets of unhappy circumstances, none of which is satisfactory from the perspective of protection of human rights or respect for the rule of law. First, sometimes, the world's vocalized support for the principles of human rights goes unenforced-the Security Council is unable to muster P5 unanimity on a timely, efficacious response and the atrocities continue. Rwanda and Bosnia may be the epitome of this failure, as the world respected the letter of the law regarding the restraints of jus ad bellum, but did little to interrupt the chain of human slaughter and suffering. ${ }^{82}$ Syria today provides another poignant illustration of the problem. ${ }^{83}$

Second, sometimes a leading country or a coalition (typically with the United States at the forefront) acts unilaterally, disregarding the absence of a Security Council mandate to stop the oppression. Kosovo is the prime illustration of this avenue; activist NATO states-concededly proceeding without a genuine legal rationale, but claiming the intervention was "justified" or "legitimate" nonetheless-saved countless lives. ${ }^{84}$ Bur it is hardly

the Responsibility to Protect Influences the Security Council's Powers, Limits and Dynamic, 4 J. INT'L. HumanITARIAN LEgal STUD. 315, 315 (2013) (studying the application of the doctrine of R2P in Libya); Interview by Emma Alberici with Sergei Lavrov, Russian Foreign Minister (Jan. 31, 2012), http://www .abc.net.au/lateline/content/2012/s3420041.htm [https://perma.cc/6VHK-LRZH] (interviewing Russian Foreign Minister Sergei Lavrov, who said, regarding the fighting in Syria, that Russia "would never allow the Security Council to authorize anything similar to what happened in Libya"); Newman, supra note 70 , at $248-50$.

Numerous other Security Council Resolutions have also cited R2P or have relied upon similar concepts. R2P References in United Nations Security Council Resolutions and Presidential Statements, GLoB. CTR. FOR ReSP. to PROTECT (May 2015), http://s156658.gridserver.com/media/files/unsc-resolutions-andstatements-with-r2p-table-as-of-may-2015.pdf [https://perma.cc/UM8W-FEQW] (citing thirty-five Security Council resolutions between January 2006 and May 2015 that directly or indirectly refer to R2P and related vocabulary); Ortega, supra note 60, at 3; Hachaway, Consent-Based, supra note 12, at $507 \mathrm{nn} .35$, 36 (summarizing recent practice of Security Council in conducting or authorizing humanitarian interventions in response to human rights emergencies); Haslett, supra note 70, at 197-201.

82. Helal, Brotber's Keeper, stipra note 32, at 448, 455-57 (noting that the Charter gives the Security Council the responsibility, but not the obligation, to address humanitarian crises); Edward C. Luck, Sovereignty, Choice and the Responsibility to Protest, 1 Glob. Resp. TO Protect 10, 19 (2009). (summarizing US view that there is no legal obligation on the Security Council to undertake enforcement operations); Andre Nollkaemper, Failure to Protect: Recent Experiences, in The OxFord Handbook of THE UsE of Force in International Law 437 (Marc Weller ed., 2015); Kim R. Holmes, The Weakness of the Responsibility to Protect as an International Norm, SMALL WARS J. (Jan. 7, 2014), http://smallwarsjournal .com/jrnl/art/the-weakness-of-the-responsibility-toprotect-as-an-international-norm [https://perma.cc/ UM4P-KBSY] ("R2P is a mere aspiration, as opposed to a real principle of international norms.").

83. See Security Conncil Must Match Scale of Syria Crisis with 'Bold Response' - UN Relief Officials, U.N. News CTR. (Apr. 24, 2015), https://www.un.org/apps/news/story.asp?NewsID=50678 [https://perma .cc/34SX-HJD3] (reporting senior UN humanitarian officials calling for more concerted action to deal with five years of crisis in Syria, which have resulted in 220,000 deaths, more than one million injuries, and almost twelve million displaced persons); Hathaway, Consent-Based, supra note 12, at 500-01; Helal, Brother's Keeper, supra note 32, at 385 (noting Russia and China vetoing Security Council resolutions about Syria); Helal, Justifying War, supra note 26, at 640; GloB. CTR. For Resp. To Protect, 21 R2P MONITOR 2-3 (May 15, 2015), http://www.globalr2p.org/media/files/r2p_monitor_may2015_final.pdf [https://perma.cc/4GGX-BBRK] (describing desperate human rights situation in Syria, noting four proposed Security Council resolutions Russia and China have vetoed).

84. See Kosovo Report, supra note 39 (reviewing the extreme human rights crisis prevailing in Kosovo and the inability to secure a UN Security Council warrant for intervention; conceding that 
satisfactory jurisprudence-and not a reliable safeguard for future incidents - to hang such important international protections on a hook that manifestly lacks legal authority. ${ }^{85}$

Third, following the form, if not the substance, of the Kosovo precedent, sometimes the world observes a pre-textual assertion of something like $\mathrm{R} 2 \mathrm{P}$, with a foreign state throwing its weight around inside a helpless neighbor while purporting to be motivated by a desire to support an oppressed minority. ${ }^{86}$ Russia's intervention inside Ukraine and its seizure of Crimea is a contemporary illustration of how the rhetoric about standing up for minority rights can be twisted into something very different. ${ }^{87}$ When

NATO military actions were "on shaky legal ground;" supporting claims that the NATO mission was illegal, yet legitimate; and calling this an exception to the standing international law rules, not a precedent for similar future operations); ICISS REPORT, supra nore 60, at 1; Harrell, supra note 28, at 425 (discussing justification for the Kosovo war); Hathaway, Consent-Based, supra note 12, at 518-21; Allain, supra note 19, at 251-55; Matthew C. WaxMan, INTER vention to Stop GenOcide and Mass Atrocities 1 1-14 (2009) (contemplating four categories of reform proposals to deal more effectively with humanitarian crises, including "break the law when necessary" and "create new international institutional bodies"); Bell, stupra note 80, at 275; Stefan Talmon, At Last! Germany Admits lllegality of the Kosovo Intervention, 57 Ger. Y.B. INT'L L. 581, 583 (2014) (arguing that the Kosovo intervention was overwhelmingly rejected by the neurral and non-aligned states).

85. See Kosovo RePort, supra note 39, at 186 (arguing that allowing a gap between legality and legitimacy "is not healthy"); W. Michael Reisman, Kosovo's Antinomies, 93 Am. J. Int'l L. 860, 860 (1999); Hathaway, Consent-Based, supra note 12, at 509-21 (surveying eight instances of international humanitarian assistance undertaken outside the Charter regime). Observers have also expressed concern that activation of the International Criminal Court's jurisdiction over the crime of aggression could deter humanitarian intervention, in the absence of clear legal standards governing the actions. Sewall, supra note 70, at 3; Koh \& Buchwald, supra note 59, at 16; see also Samantha Power, US Permanent Representative to the U.N., Remarks at the American Enterprise Institute on UN Peacekeeping Reform (Nov. 7, 2014), http://usun.state.gov/remarks/6283 [https://perma.cc/3284-DW8L].

86. Some states and commentators have reacted against the concept of R2P, seeing it as a cover for neo-imperialism and interventionism, allowing big, powerful states to impose their will against the weaker states and denying them full sovereignty, or as a snare that might obligate the United States to undertake unwise interventions. Richardson, supra note 73, at 42-43; Hathaway, Consent-Based, supra note 12, at 535-38 (noting risks inherent in departing from reliance upon the Security Council, including the increased dangers of wars waged for pre-textual justifications); Tom J. Farer, An Inquiry into the Legitimacy of Humanitarian Intervention, in LaW aNd FORCE iN THE New INTERNational ORDer, 185, 192-93 (Lori F. Damrosch \& David J. Scheffer eds., 1991) (arguing that there has never been an intervention inside another state undertaken for the exclusive purpose of protecting human rights); Noam Chomsky, Humanitarian Imperialism: The New Doctrine of Imperial Right, MonTHLY Rev., Sept. 2008, at 22; Goodman, supra note 73, at 113 (noting that Hitler had invoked rhetoric similar to that of R2P in cynical justification for his demands against Czechoslovakia prior to World War II); Monica Serrano, The Responsibility to Protect and Its Critics: Explaining the Consensus, 3Glob. Resp. To ProteCt 425, 425 (2011); Aidan Hehir, The Responsibility to Protect: 'Sound and Fury Signifying Nothing'?, 24 INT'L. Rel. 218, 218-219 (2010); Steven Groves, Obama Wrongly Adopts U.N. "Responsibility to Protect" to Justify Libya Intervention, HerrTAGe Found. (Mar. 31, 2011), http://www.heritage.org/research/reports/2011/03/libya-intervention-obama-wrongly-adopts-un-responsibility-to-protect [https://perma .cc/GR7H-JZED]; Kim R. Holmes, The Failure of an Idea, Heritage Found. (Mar. 21, 2012), http:// www.heritage.org/research/commentary/2012/03/the-failure-of-an-idea [https://perma.cc/KLB2KY3T].

87. See Veronika Bílková, The Use of Force by the Russian Federation in Crimea, 75 Herdelberg J. INT'L L. 27 (2015) (describing Russia's "humanitarian intervention" in Ukraine, allegedly undertaken in part to protect Ukrainian nationals, some of whom had been granted Russian citizenship); David S. Yost, The Budapest Memorandum and the Russia-Ukraine Crisis, WAR ON THE Rocks (June 10, 2015), http://warontherocks.com/2015/06/the-budapest-memorandum-and-the-russia-ukraine-crisis/ [https:// 
the longstanding structures of jus ad bellum, reposing in the Security Council a monopoly on the legal use of force, are unraveled, the potential for cynical abuse rises. ${ }^{88}$

A New Mechanism. One possible way out of this box, therefore, might be to contract around the Security Council, to create a new legal avenue for authorization of military force in selected human rights cases. If the world wants these types of R2P functions to be performed, and if Chapter VII is too often stymied by the veto power, then a new and different legal theory is required. One such vehicle would be to establish a new, more democratic international organization by treaty, empowered by its terms to authorize military action as a last resort against any treaty party that committed (or failed to prevent) gross human rights atrocities.

Such a structure could be fabricated by a new, general-purpose R2P Treaty or by a protocol ${ }^{89}$ to an existing instrument such as the Genocide Convention or the Convention Against Torture. It could be of global or restricted reach; numerous implementation details are noted infra.

Path-breaking analysts, most prominently Tom J. Farer, David Wippman, and Oona Hathaway, have assessed the notion of amplifying the

perma.cc/4SBP-SLHS] (noting that Russian President Vladimir Putin offered several justifications for Russian intervention in Crimea, including Ukraine's suppression of its Russian-language-speaking citizens); Thomas D. Grant, Current Developments: Annexation of Crimea, 109 Aм. J. INT'1. L. 68, 80-81 (2015) (noting that Russia asserted that its action in Ukraine was intended to protect both Russian nationals living there and Ukrainian nationals of Russian ethnicity); see also Hathaway, Consent-Based, supra note 12, at 537 (discussing Russia's intervention in Georgia in 2008, which was widely condemned by the international community as not being truly motivated by humanitarian instincts); Haslett, supra note 70, at 212-14; Shane Reeves \& Winston Williams, The Road from Syria to Ukraine, AM. Soc'y INT't L. (July 21, 2015), https://www.asil.org/insights/volume/19/issue/16/road-syria-ukraine [https://perma.cc/ZAN2-PKK9] (noting that Putin claimed to be defending the rights of minorities from real threats to their lives and health).

88. ICISS REPORT, supra note 60, at 55 ("It is a real question in these circumstances where lies the most harm: in the damage to international order if the Security Council is bypassed or in the damage to that order if human beings are slaughtered while the Security Council stands by."); Ian Brownlie, Thoughts on the Kind-Hearted Gunmen, in Humanitarian INTERVENTION AND THE UNITED Nations 139, 147-48, (Richard B. Lillich ed., 1973) ("Whatever special cases one can point to, a rule allowing humanitarian intervention, as opposed to a discretion in the United Nations to act through the appropriate organs, is a general license to vigilantes and opportunists to resort to hegemonial intervention."); Ortega, supra note 60, at 4-5 (reporting that several countries remain skeptical about the concept of intervention under R2P); Evans, supra note 41, at 289 (describing backlash against the concept of R2P); Ruan Zongze, Responsible Protection, CHINA-US Focus (Mar. 16, 2012), http://www.chinausfocus.com/ foreign-policy/responsible-protection/ [https:/perma.cc/5EVE-RMNY] (reporting views of some countries who see the doctrine of $\mathrm{R} 2 \mathrm{P}$ as an excuse for hegemony and intervention by wealthy Western countries in the internal affairs of poor states); Luck, supra note 82, at 17-18; Reeves \& Williams, supra note 87 , at 1-2 (asserting that Putin's specious claims to be acting in support of human rights while intervening in Ukraine are "eerily similar" to arguments made by other world leaders in favor of intervention in Syria); Talmon, supra note 84, at 5-6 (evaluating comparisons between Kosovo and Ukraine); Transcript: Putin Defends Russian Intervention in Ukraine, Wash. POST (Mar. 4, 2014), https:// www. washingtonpost.com/world/transcript-putin-defends-russian-intervention-in-ukraine/2014/03/04/ 9cadcd1a-a3a9-11 le3-a5fa-55f0c77bf39c_story.html [https://perma.cc/EK27-9JMU].

89. There is no essential difference between a treaty and a protocol; under the Vienna Convention on the Law of Treaties, the name of the instrument is immaterial. Supra note 61, art. 2.1(a). Frequently, the designation "protocol" is applied to a modification or addendum to an existing treacy. 
reach of R2P in this way. ${ }^{90}$ Farer has argued in favor of allocating new power to "subglobal intergovernmental organizations with geographically diverse membership," to exercise coercive power if the Security Council is unable to guarantee minimum global public order and respect for fundamental human rights. ${ }^{91}$ Despite the dangers of diluting the Security Council's monopoly on the authorization of enforcement actions, and the consequent breakdown in global order, Farer concludes that decentralizing these powers would enable more effective pursuit of human rights and other goals, while still helping to subdue the impulse to unilateral action. ${ }^{92}$

Wippman has likewise examined "treaty-based interventions," documenting a surprising array of existing and proposed international agreements whereby a sovereign consents in advance to allowing its neighbors (or others) to apply military power against itself, in order to preserve or restore a democratic government (e.g., in response to a coup), to interdict gross human rights violations, or for other purposes. ${ }^{93}$ He provides a "qualified yes" to the question of the validity of these regimes, finding that sometimes, the injection of outside force, even without Security Council endorsement, can contribute to the resolution of otherwise-intractable internal conflicts. ${ }^{94}$

Hathaway and her colleagues have proposed "consent-based humanitarian intervention" as a mechanism for more effectively balancing the interests of "sovereign rights" (i.e., the Charter's extraordinary protection against unwarranted foreign interventions) vs. "sovereign responsibilities" (i.e., the imperative of protecting fundamental human rights).95 After surveying numerous instances of humanitarian interventions undertaken outside the UN regime, they conclude that a state's voluntary a priori consent can validate subsequent forceful intervention by humanitarian treaty partners. ${ }^{96}$

90. See also Lieblich, supra note 15; Harrell, supra note 28; Jeremy I. Levitt, Pro-Democratic Intervention in Africa, 24 WIS. INT'L L.J. 785 (2006); Reisman, Sovereignty and Human Rights in Contemporary International Law, supra note 41, at 859-60; Brad R. Roch, The Illegality of "Pro-Democratic" Invasion Pacts, in Democratic Governance and International. Law 328 (Gregory H. Fox \& Brad R. Roth eds., 2000); Gregory H. Fox, Intervention by Invitation, in THE OXFord HANDBOoK of THE UsE OF ForCe iN INTERNATIONAL LAW 816, 831-33 (Marc Weller ed., 2015).

91. Tom Farer, A Paradigm of Legitimate Intervention, in Enforcing Restraint: Collective INTERvention in Internal Conflicts 316, 331-41 (Lori Fisler Damrosch ed., 1993) [hereinafter Farer, Paradigm]; Farer, Guarantor of Democracy, stura note 14; Tom J. Farer, The Role of Collective Security Arrangements, in Coltectrve Security in a Changing World 153 (Thomas G. Weiss ed., 1993).

92. Farer, Paradigm, supra nore 91, at 340-41.

93. David Wippman, Treaty-Based Intervention: Who Can Say No?, 62 U. CHI. L. Rev. 607, 684 (1995) [hereinafter Wippman, Treaty-Based]; Wippman, Nine Lives, supra note 17, at 393-94; Wippman, Military Intervention, supra note 28, at 210-11; David Wippman, Pro-Democratic Intervention by Invitation, in Democratic Governance and International Law 293 (Gregory H. Fox \& Brad R. Roth eds., 2000); David Wippman, Pro-Democratic Intervention, in THE OXFord HaNdBook OF THE Use of ForCE in INTERnational Law 797, 808-14 (Marc Weller ed., 2015).

94. Wippman, Treaty-Based, supra note 93, at 684 .

95. Hathaway, Consent-Based, supra note 12.

96. Id. 
In sum, the protection and promotion of fundamental human rightsspecifically, the imperative for a new legal instrument to vindicate the measures advocated by a "hard" version of R $2 \mathrm{P}$-provide our first illustration of the necessity of developing a mechanism to circumvent the P5 veto power in the Security Council. The world currently stands on the cusp of the development of this controversial proposition-it has been vigorously and widely advanced, but is far from universally accepted. For our second case study of the proposed mechanism, we now turn to a very different realm, nuclear arms control.

\section{Part III: Enforcement of Nuclear Disarmament}

If the concept of R2P can be characterized as an "emerging norm" in the human terrain of international law, then the investigation of possibilities for nuclear disarmament must be regarded as even more inchoate. To be sure, the vision of abolishing nuclear weapons is as old as nuclear weapons themselves, with early, prescient scientists, political leaders, and concerned citizens striving earnestly to rescue humanity from the awesome power that had ended World War II and threatened to stimulate an even more catastrophic World War III. ${ }^{97}$ In the ensuing decades, the goal of nuclear disarmament floated uneasily through the machinations of Cold War politics, with a string of non-governmental organizations, big powers, and non-aligned leaders sponsoring overlapping and competing proposals that were destined (sometimes seemingly designed) to go nowhere. ${ }^{98}$

97. See Sandi E. Cooper \& Lawrence S. Wittner, Transnational Peace Movements and Arms Control, in 1 Encyclopedia of Arms Control and Disarmament 491, 498 (Richard Dean Burns ed., 1993) (noting a small but influential movement of atomic scientists engaged in nuclear arms control advocacy starting in 1945); Walter Isaacson, Chain Reaction: From Einstein to the Atomic Bomb, Discover, Mar. 2008, http://discovermagazine.com $/ 2008 / \mathrm{mar} / 18$-chain-reaction-from-einstein-to-the-atomic-bomb [https://perma.cc/KCR2-EMYS]; Albert Einstein, Hist. Soc'y PrINCETON, http://www.princetonhistory .org/collections/albert-einstein.cfm (last visited Mar. 3, 2016) [https://perma.cc/WB9D-PL9Q].

98. See alva Myrdal, The Game of Disarmament: How the United States and Russia Run THE ARMS RACE 23-32 (1976) (arguing that the superpowers were not truly interested in nuclear arms control during the cold war). There were also other prominent, but ult imately ineffective, proposals for nuclear disarmament. Informal. Group on Prime Minister Rajiv Gandhís action Plan for a Nuclear-Weapons-Free and Nonviolent World Order 1988, Report of the Informal. Group on RGAP 88 (Aug. 20, 2011), http://www.pugwashindia.org/images/uploads/Report.pdf [https://per ma.cc/JQU7-2EGP]; The CanberRa Commission on the Elimination of Nuclear Weapons, http:/ /www.ccnr.org/canberra.html (last visited Mar. 4, 2015) [https:/perma.cc/64]A-4DH3]; THE WEAPons of Mass Destruction Commission, Weapons of Terror: Freeing the World of Nuclear, Biological and Chemical ARMS 59-73 (2006), http:/www.blixassociates.com/wp-content/uploads/ 2011/02/Weapons_of_Terror.pdf [https://perma.cc/JQJ6-5QE6]; SteERING CommitteE ProJeCT ON Eliminating Weapons of Mass Destruction, An American Legacy: Building a NuclearWeapon-Free World 1-5 (1997); Robert D. Green, Middle Powers Initiative, Fast Track to ZERO NuCleAr WEAPONS 13-21 (1999), http://www.ippnw.org/pdf/fast-track-to-zero-nuclear-weapons .pdf [https://perma.cc/WDC2-HJQ6]. 
Most notably, the 1968 Nuclear Non-Proliferation Treaty (NPT), 99 the centerpiece of the crucial global effort to restrict the further spread of nuclear weapons, imposes on its 191 parties $^{100}$ (including each of the P5 and currently all but four other states) a legally-binding obligation under Article VI "to pursue negotiations in good faith on effective measures relating to the cessation of the nuclear arms race at an early date and to nuclear disarmament." 101 The adequacy of P5 performance under the treaty's "good faith" obligation has remained tremendously controversial within NPT circles; indeed, many adamant states have insistently pressed for more vigorous progress away from the perpetuation of a nuclear-weapons-based security paradigm. ${ }^{102}$

For one shining moment-during the October 11-12, 1986 summit meeting in Reykjavik, Iceland between US President Ronald Reagan and Soviet General Secretary Mikhail Gorbachev-it appeared that revolutionary progress toward nuclear disarmament might be achieved; but at the last moment, that bold aspiration eluded the leaders' grasp. ${ }^{103}$ Instead, for most of the post-World War II era, the whole concept of nuclear abolition was relegated to a remote back burner, dismissed as hopelessly idealistic and fardistant. Little more than lip service accompanied the occasional invocations of NPT Article VI and "realists" demanded focusing attention on more modest, attainable, incremental objectives. ${ }^{104}$

99. Treaty on the Non-Proliferation of Nuclear Weapons, July 1, 1968, 21 U.S.T. 483, 729 U.N.T.S. 161 [hereinafter NPT].

100. See Thomas Graham, Jr., Disarmament Sketches: Three Decades of Arms Control AND INTERnational Law 257-93 (2002) (discussing the operation and importance of the NPT); Treaty on the Non-Proliferation of Nuclear Weapons, U.N. Office for Disarmament Affairs, http://disarmament.un.org/treaties/t/npt (last visited Mar. 5, 2016) [https://perma.cc/4C3S-DFD4].

101. NPT, supra note 99, art. VI.

102. Thomas E. Doyle II, Moral and Political Necessities for Nuclear Disarmament: An Applied Etbical Analysis, 9 Strategic StUd. Q., Summer 2015, at 19 (noting the urgent reiteration of the demands for nuclear weapons abolition); Robert Alvarez, The Marshall lslands and the NPT, BULLETIN OF THE Atomic Scientists (May 27, 2015), http://thebulletin.org/marshall-islands-and-npt8341 [https://per ma.cc/PQP7-GQ2N] (discussing suit brought in the International Court of Justice by the Republic of the Marshall Islands against the nine states possessing nuclear weapons, arguing that they have failed their legal obligation to proceed toward nuclear disarmament).

103. At the Reykjavik summit, the two national leaders ran far beyond their respective advisors and the anticipated agenda for the meeting, toward an agreement to eliminate all nuclear weapons. Because of persistent differences over missile defenses, they were unable to conclude an agreement, and no effective follow-up discussions were conducted. See Implications of the ReykJavik SUMmit on ITs Twentieth Anniversary 139 (Sidney D. Drell \& George P. Shultz eds., 2007); Reykjavik Revisited: Steps Toward a World Free of Nuclear Weapons 475 (George P. Shultz, Steven P. Andreasen, Sidney D. Drell \& James E. Goodby eds., 2008); Thomas Blanton \& Svetlana Savranskaya, Reykjavik: When Abolition was Witbin Reach, Arms Control Ass'N (Sep. 30, 2011), http://www.armscon trol.org/act/2011_10/Reykjavik_When_Abolition_Was_Within_Reach [https://perma.cc/B33XQHXR].

104. George Perkovich \& James Acton, Abolishing Nuclear Weapons 83 (2008), reprinted in George Perkovich \& James Acton, Abolishing Nuclear Weapons, in CARNeGie ENDOWMent FOR INTERnational Peace, Abolishing Nuclear Weapons: A Debate 9 (George Perkovich \& James Acton eds., 2009) [hereinafter DeвATE] (commenting that after the 1940s, "[t] the total elimination of nuclear arsenals almost disappeared from the incernational agenda until after the Cold War"); Alessandro Corradini, General and Complete Disarmament, in 2 Encyclopedia of ARMs CONTrol and Disarmament 
That complacent stasis was shattered in 2007 by the publication of the first, in what became a persistent series of editorial broadsides by a "Gang of Four" retired senior US statesmen, George P. Shultz, William J. Perry, Henry A. Kissinger, and Sam Nunn. ${ }^{105}$ They electrified the US and global national security community by zealously advocating prompt and emphatic re-affirmation of the objective of "getting to zero" nuclear weapons and the pursuit of an ambitious agenda of specific and sustained practical steps toward the achievement of that elusive goal. ${ }^{106}$ Prompted by that startling clarion call, a cascade of world leaders effusively endorsed nuclear disarmament and a wellspring of books, articles, speeches, and orher works appeared, seconding the initiative and analyzing the path forward. ${ }^{107}$

Most prominently, President Barack Obama emphatically espoused "zero" advocacy, asserting in his celebrated Prague speech on April 5, 2009, "So today, I state clearly and with conviction America's commitment to seek the peace and security of a world without nuclear weapons."108 Likewise, the other P5 fell into line, with the Security Council committing in Resolution 1887 on September 24, 2009, "to seek a safer world for all and to create the conditions for a world without nuclear weapons" in accordance with the goals of the NPT. ${ }^{109}$

Most recently, as the US-Russian dialog on arms control has soured due to other political controversies, other insistent voices have also expressed

1041, 1226 (Richard Dean Burns ed., 1993); Randy Rydell, Nuclear Disarmament and General and Complete Disamament, in The Challenge of Abolishing Nuclear Weapons 227-29 (David Krieger ed., 2009) (describing the history and implications of the concept of abolishing nuclear weapons).

105. George P. Shultz, William J. Perry, Henry A. Kissinger \& Sam Nunn, A World Free of Nuclear Weapons, WALL StREeT J. (Jan. 4, 2007), http://www.wsj.com/articles/SB116787515251566636 [https://perma.cc/QY75-UEKV].

106. The four called for "intensive work with leaders of the countries in possession of nuclear weapons to turn the goal of a world without nuclear weapons into a joint enterprise," and they identified "a series of agreed and urgent steps that would lay the groundwork for a world free of the nuclear threat," including relaxation of the alert posture of nuclear missiles, elimination of short range nuclear weapons, and improved nuclear security. See $i d$.

107. Philip Taubman, The Partnership: Five Cold Warriors and Their Quest to Ban the Bomb (2012); see also Getring to Zero: The Path to Nuclear Disarmament 28-30 (Catherine McArdle Kelleher \& Judith Reppy eds., 2011); Debate, supra note 104; George P. Shultz, William J. Perry, Henry A. Kissinger \& Sam Nunn, Toward a Nuclear-Free World, WALL Street J. (Jan. 15, 2008), http://www.wsj.com/articles/SB120036422673589947 [https://perma.cc/G9RC-7XUE] (noting that the Gang of Four had received indications of support from many former senior US government officials); Sidney D. Drell \& James E. Goodby, A World Without Nuclear Weapons: End-State Issues 1-2 (2009) [hereinafter END-STATE Issues]; Ivo Daalder \& Jan Lodal, The Logic of Zero: Toward a World Without Nuclear Weapons, Foreign AfF., Nov.-Dec. 2008, at 80-95; Christopher A. Ford, A New Paradigm: Shattering Obsolete Thinking on Arms Control and Nonproliferation, 38 ARmS CONTROL TODAY, Nov. 2008, at 12, https:/www.armscontrol.org/act/2008_11/ford [https://perma.cc/PM9X-YKR3].

108. President Barack Obama, Remarks by President Obama in Prague (Apr. S, 2009), http://www .whitehouse.gov/the_press_office/Remarks-By-President-Barack-Obama-In-Prague-As-Delivered/ [https://perma.cc/86RU-5VQS].

109. S.C. Res. 1887, 11 (Sept. 24, 2009). 
ardor for complete nuclear disarmament. ${ }^{110} \mathrm{~A}$ series of major international conferences on the "humanitarian" aspects of nuclear disarmament-in Norway, Mexico, and Austria-highlighted the world's shared stake in avoiding any use of nuclear weapons and the multilateral judgment that complete abolition remains the only route for ensuring our species' survival. 11 At the 2015 Review Conference for the NPT, the states that have legally foresworn any nuclear weapons in perpetuity again challenged the P5 about their failure to vindicate their Article VI obligations and negotiate and conclude additional measures to drastically draw down their arsenals. ${ }^{112}$

Necessary Features for a Zero Treaty. Not surprisingly, the outpouring of far-sighted literature about nuclear disarmament has focused principally on the myriad political, military, and technical nettles that will have to be grasped in any conceivable Zero Treaty. ${ }^{113}$ Of course, great attention has been lavished on the modalities for "verification" of compliance-the devices and procedures for gathering and processing the information that can enable each state to be confident that its erstwhile adversaries are faithfully honoring their disarmament obligations. ${ }^{14}$ Various portraits for the "insti-

110. See Alexei Arbatov, Carnegie Moscow Center, An Unnoticed Crisis: The End of History for NUClear ARMS CONTrol? 3, 22 (2015) (observing that bilateral US-Russian negotiations on nuclear arms reductions and nonproliferation "have come to a dead end").

111. See Nick Ritchie, The Humanitarian Initiatjve in 2015 (2015); Rebecca Johnson, NPT: Cornerstone of Nuclear Non-Proliferation or Stumbling Black?, OPENDEMOCRACY (May 28, 2015), https:// www.opendemocracy.net/5050/rebecca-johnson/npt-107-nations-pledge-to-negotiate-on-nuclear-disarmament [https://perma.cc/V67D-JU98]; Onur Guven \& Sico van der Meer, A Treaty Banning Nuclear Weapons and Its Implications for the Netherlands, CLINGENDAEL 1-2 (May 2015), http://www.clingendael .nl/sites/default/files/A\%20treaty\%20banning\%20nuclear\%20weapons\%202015.pdf [https://perma.cc/ YF45-J837\}; Tim Caughley, Analyzing Effective Measures: Options for Multilateral NuClear Disarmament and Implementation of NPT ARticle VI (2015), http:/unidir.ilpi.org/wpcontent/uploads/2015/04/No-3-Effective-Measures-TC.pdf [hrtps://perma.cc/7AUS-VSRJ].

112. See Daryl G. Kimball \& Kingston Reif, NPT Conference Fails to Reach Consenstus, 45 Arms Control TODAY, June 2015, at 5, https://www.armscontrol.org/ACT/2015_06/News/NPT-Conference-Fails-To-Reach-Consensus [https://perma.cc/LWN3-JTHQ]; Andrea Berger, Gangs of New York: The 2015 NPT Revcon, Eur. Leadership Network (May 27, 2015), http://www.europeanleadershipnetwork.org/gangs-of-new-york-the-2015-npt-revcon_2790.html [https://perma.cc/9YRT-RYZN].

113. See generally The Challenge of Abolishing Nuclear Weapons, stipra note 104; End-State Issues, supra note 107, at 227-29; Elements of a Nuclear Disarmament Treaty (Barty M. Blechman \& Alexander K. Bollfrass eds., 2010); Ctr. for Int'l Sec. and Cooperation, Stanford Univ., Rebuilding the NPT Consensus 199-217 (Michael May ed., 2007), http://fsi.stanford.edu/ sites/default/files/RebuildNPTConsensus.pdf [https:/perma.cc/DWF4-T5JX]; NUCLEAR WEAPONS: The Road to Zero 155 (Joseph Rotblat ed., 1998); Caughley, supra note 111, at 1-9; Debate, supra note 104 .

114. See Cultivating Confidence: Verification, Monitoring, and Enforcement for a World Free of Nuclear Weapons xi-xix (Corey Hinderstein ed., 2010); End-State Issues, supra note 104, at 15-24; Steve Fetter \& Ivan Oelrich, Verifying a Probibition on Naclear Weapons, in ElemeNTs of a Nuclear Disarmament Treaty 27 (Barry M. Blechman \& Alexander K. Bollfrass eds., 2010); Debate, supra note 104, at 49-82; Rose Gottemoeller, Acting Under Sec'y for Arms Control and Int'l Security, Remarks in Helsinki, Finland on Arms Control in the Information Age: Harnessing "Sisu" (Aug. 29, 2012), http:/www.state.gov/t/us/197056.htm [https://perma.cc/8P7S-ZMNQ] (highlighting U.S. Department of State's search for creative new concepts for verification of arms control treaties); Raymond J. Juzaitis \& John E. McLaughlin, Challenges of Verification and Compliance witbin a State of Universal Latency, in Reykjavik Revisited Steps Toward a World Free of Nuclear Weapons, 
tutional" apparatus of a Zero Treaty regime have also emerged, sketching a new international organization that would have to be created to manage the verification operations, clarify ambiguities about implementation, and resolve disputes. ${ }^{15}$

Less notice has been paid to the vexing companion question of "enforcement"- what should be done if parties do discern a breach (large or small) of the treaty. ${ }^{116}$ To be viable, a Zero Treaty must incorporate mechanisms that would effectively deny a violator any militarily-significant benefits. A Zero Treaty must deter cheating by some combination of sure, swift detection and condemnation, timely offsetting military reactions by other states, and meaningful punishment. Underpinning any analysis is a judgment that, by the time a Zero Treaty is ripe, countries and their citizens must have adopted rather different attitudes toward traditional aspects of national secrecy, sovereignty, and autonomy. They thus must be prepared to embrace a degree of progressive openness, cooperation, accommodation, and resolve that is currently hard to imagine or to plan. Concerted action to

supra note 103, at 159-203; Edward Ifft, Monitoring Nuclear Warbeads, in ReykJAvik Revisited StePS Toward a World Free of Nuclear Weapons, supra note 103, at 229-42; James Fuller, Verification on the Road to Zero: Isstes for Nuclear Warbead Dismantlement, ARms Control Ass'N (Dec. 2010), http:// www.armscontrol.org/act/2010_12/\%20Fuller [https:/perma.cc/2PF5-VKBG]; AMY F. Woolf, Cong. Research Serv., Monitoring and Verification in Arms Control (2011).

115. See Alexander K. Bollfrass, Governance of a Nuclear Disamament Treaty, in ELEMENTS OF A Nuclear Disarmament Treaty 179-208 (Barry M. Blechman \& Alexander K. Bollfrass eds., 2010); Jurgen Scheffran, A Nuclear Weapons Convention: Patb to a Nuclear Weapon-Free World, in The CHALIENGE of Abolishing Nuclear Weapons, supra note 104, at 171; Emesto Zedillo, The Role of International Institutions in the Disamament Process, in DeBate, supra note 104, at 287-93; Ronald McCoy, The Case for a Nuclear Weapons Convention, in The Challenge of Abolishing Nuclear Weapons, supra note 104, at 185-94; In't' Physicians for the Prevention of Nuclear War, INT'l Ass'n of Lawyers Against Nuclear arms \& Int'l Network of Engineers and Scientists Against Proliferation, Securing Our Survival (SOS): The Case for a Nuclear Weapons Convention (2007), htep:// www.lcnp.org/pubs/2007-securing-our-survival.pdf [https://perma.cc/3CTB-YA34] [hereinafter Nuclear Weapons Convention]; Chargé d'affaires a.i. of the Permanent Mission of Costa Rica, Letter dated 31 October 1997 from the Chargé d'affaires a.i. of the Permanent Mission of Costa Rica to the United Nations addressed to the Secretary-General, U.N. Doc. A/C.1/52/7, at 70-78 (Nov. 17, 1997), http://www.un.org/ga/search/view_doc.asp?symbol = A\%2FC. $1 \% 2 F 52 \% 2 F 7 \&$ Lang =E [https://perma .cc/2PLX-BSZ7] (describing the agency that would be created under the proposed nuclear weapons convention); David A. Koplow, What Would Zero Look Like? A Treaty for the Abolition of Nuclear Weapons, 45 GEO. J. OF INT'L L. 683, 769 (2014) (presenting organizational arrangements for a Zero Treaty); Fred C. Ikle, Nuclear Abolition, a Reverie, THE NAT'L INT., Sept.-Oct. 2009, at 4 (expressing doubts about the creation of a sufficiently powerful international organization to implement a nuclear disarmament treaty).

116. Alexander K. Bollfrass, Breaking Out of Zero: Would Cheating Be Wortb the Risk?, in ElemENTS of a Nuclear Disarmament Treaty 209 (Barry M. Blechman \& Alexander K. Bollfrass eds., 2010); Rebecca Bornstein, Enforcing a Nuclear Disamament Treaty, in Elements of a Nuclear Disarmament Treaty 149, 151-55 (Barry M. Blechman \& Alexander K. Bollfrass eds., 2010) (stressing parties' positive incentives to comply with a nuclear disarmament treaty); DEBATE, supra note 104, at 99-115 (regarding options for enforcement); Harald Muller, Enforcing Zero: Forget Deterrence!, in Deter rence: Its Past and Future 373 (George P. Shultz, Sidney D. Drell \& James E. Goodby eds., 2011); Patricia Lewis, Verification, Compliance and Enforcement, in DEBATE, supra note 104, at 233; Harald Muller, Enforcement of the Rules in a Nuclear Weapon-Free World, in Cultivating Confidence: Verification, Monitoring, and Enforcement for a World Free of Nuclear Weapons 33, 35 (Corey Hinderstein ed., 2010) (calling enforcement the "Achilles' heel of the vision of a nuclear weapon-free world"). 
redress a violation-by applying deft multinational diplomatic, economic, military and other pressures-will have to be made available, on a reliable, timely basis. ${ }^{117}$

Some proposed approximations of an enforcement regime have emerged, but generally without the detailed analysis and drafting that have accompanied other aspects of this futurology. To a large extent, the questions about modalities for effective enforcement have simply been "punted," awaiting later imagination and evolution. ${ }^{118}$

On some aspects, however, the portrait is clear. First, as an ultimate fallback mechanism, recourse to military force may be necessary. Diplomatic, economic, and other non-violent enforcement mechanisms will be critical and would be counted upon, in most cases, to carry the necessary weight. But for a treaty of this consequence, application of coercive armed might remains the ultimate safeguard for the disarming states. Second, for this purpose, reliance upon the current Security Council alone will be inadequate-the persistence of the veto power robs the Security Council of the ability to present itself as a reliable guarantor of a Zero Treaty. ${ }^{119}$

Overall, advocates must imagine that by the time a Zero Treaty is ready for implementation, there will be significant transformations in international political relationships-but they do not posit that all potential global antagonisms will have been amicably resolved. ${ }^{120}$ The potential for international conflict-including persistent political and military tensions, even some that pit members of the P5 on opposite sides-will linger indefinitely. It would therefore be inadequate to depend, as the last-ditch enforcement mechanism for a treaty abolishing nuclear weapons, upon the caprice of the P5 veto power.

International Law for Enforcement of a Zero Treaty. In that projected environment, contemporary international law offers little comfort. As noted supra in the R2P context, ${ }^{121}$ traditional remedies for breach of a treaty, such as those pursuant to Article 60 of the Vienna Convention on the Law of

117. See Jonathan Schell, The Folly of Arms Control, 79 Forejgn Afr. 22, 44 (2000), https://www foreignaffairs.com/articles/2000-09-01/folly-arms-control [https://perma.cc/R576-RSSA] (arguing that if the leading states were to commit themselves to a treaty eliminating nuclear weapons, they would pursue rigid new verification arrangements with unprecedented zeal and create a robust regime, despite any concerns about national privacy and secrecy).

118. Nuclear Weapons Convention, supra note 116, at 86-91, 109-11; see also Koplow, supra note 115, at 720-27, 773-74; DEBATE, supra note 104, at 99 (noting that the challenges of enforcement for a Zero Treaty have been "under-addressed").

119. See Barry Blechman, Stop at Start, N.Y. Times, Feb. 19, 2010, at A27, htrp://www.nytimes .com/2010/02/19/opinion/19blechman.html?_r=0 [https://perma.cc/6PC6-9Z3Q]; DEBATE, supra note 104, at 104-08; Muller, Enforcement of the Rules in a Nuclear Weapon-Free World, supra note 116, at $47-50$.

120. Jack F. Matlock Jr., Regional Animosities and Nuclear Weapons Proliferation, in ReykJavik RevisITED StePs Toward a WORLd Free of NuClear Weapons, supra note 103, at 399-424 (arguing that abolition of nuclear weapons would require amelioration, but not necessarily resolution, of regional tensions).

121. See supra text accompanying notes $62-63$. 
Treaties, ${ }^{122}$ would be mostly unavailing. Those remedies would enable an innocent state, aggrieved by another party's material breach of the Zero Treaty, to suspend or terminate its own counter-performance, in whole or in part. In some hypothetical scenarios, that approach might empower a suitable response, but it would generally lead to the disintegration of the treaty rather than its restoration or the violator's return to compliance.

Similarly, renunciation or withdrawal from the treaty might not fully serve the innocent party's true interests. Most modern arms control treaties have incorporated, in some fashion, a "supreme interests withdrawal clause," pursuant to which a state is permitted, in the exercise of its national sovereignty, to exit the regime abruptly if it determines that extraordinary events related to the subject of the treaty have jeopardized its paramount interests. ${ }^{123}$ Typically, the withdrawing state is obligated to provide three or six months advance notice of such withdrawal and to state the reasons why it considers its interests so jeopardized, but the country is selfjudging in making these determinations. ${ }^{124} \mathrm{~W}$ ithdrawals from arms control treaties have been rare, with only two precedents to date. ${ }^{125}$ Negotiators of the future Zero Treaty will have to determine whether to authorize this type of withdrawal, ${ }^{126}$ but even if they do include some version of that safety valve, it, too, can lead toward splintering, rather than to effective implementation of the agreement.

A state that perceives a pending or actual violation of the Zero Treaty might retaliate by undertaking its own offsetting military build-up, per-

122. See VCLT, supra note 61, art. 60; see also Restatement, supra note $62, \S 335$.

123. The model for these provisions comes from the NPT, which provides that each party, in exercising its national sovereignty, has the right to withdraw "if it decides that extraordinary events relared to the subject matter of this Treaty, have jeopardized the supreme interests of its country." Supra note 99, art. X.1; see also, e.g., Convention on the Prohibition of the Development, Production, Stockpiling and Use of Chemical Weapons and on Their Destruction art. XCI.2, Jan. 13, 1993, 1974 U.N.T.S. 317 [hereinafter CWC]; The Comprehensive Nuclear-Test-Ban Treaty art. IX.2, Sept. 24, 1996, 34 I.L.M. 1439 (not in force) [hereinafter CTBT]; Guido den Dekker \& Tom Coppen, Termination and Suspension of, and Withdrawal from, WMD Arms Control Agreements in Light of the General Law of Treaties, 17 J. of Conflict \& SeCurity L. 25, 33-38 (2012).

124. See NPT, supra note 99, art. X.1 (requiring three months' notice before withdrawal); CWC, supra note 123, art. XVI.2 (requiring 90 days' notice); CTBT, supra note 124, art. IX.3 (requiring six months' notice).

125. The only two examples are the 2002 U.S. withdrawal from the Treaty on the Limiration of Anti-Ballistic Missile Systems and the 2003 North Korean withdrawal from the NPT. See also Den Dekker \& Coppen, supra note 123, at 30, 44-46; Christer Ahlstrom, Witbdrawal from Arms Control Treaties, in Stockholm International Peace Research Institute, SPRI Yearbook 2004764 (2004), http://www.sipri.org/yearbook/2004/files/SIPRIYB0419.pdf [https://perma.cc/T4KD-EVSQ].

126. See Nuclear Weapons Convention, supra note 115 , at 96 (disallowing withdrawal); Koplow, supra noce 115, at 778 (allowing withdrawal on the standard terms); DEBATE, sutpra noce 104, at 111-13. Treaty makers should also address the questions of whether the treaty should continue, be suspended, or terminate as a result of armed conflict among the parties, see den Dekker and Coppen, supra note 123 , at 39-42, and whether any treaty obligations would continue to run, even after a withdrawal, see Antonio F. Perez, Survival of Rights Under the Nuclear Non-Proliferation Treaty: Withdrawal and the Continuing Right of International Atomic Energy Agency Safegnards, 34 VA. J. OF INT'L L. 749 (1994) (arguing that some NPT responsibilities continued in force, even after North Korea withdrew from that treaty). 
haps including initiating or restoring its own nuclear arsenal. That tit for tat reprisal ${ }^{127}$ might succeed in restoring a measure of balance, re-creating approximately the deterrence structure that has characterized almost the entire post-World War II era security relationship. But there is no guarantee that the "second mover" could reconstitute a workable nuclear arsenal quickly enough to catch up to the initial violator and offset any secret head start. Moreover, those gyrations of renewed frenzied nuclear arms racing might be the most dangerous and destabilizing moments for any mounting crisis. ${ }^{128}$

The Exercise of Self-Defense. An individual state (or like-minded coalition) might therefore decide to launch a unilateral military strike, attempting to destroy or disable the violator's emerging nuclear weapons capability before it reaches fruition. If the treaty-compliant state determines that its security so demands, and if there is no alternative mechanism for vindicating its legal right to be free from this "breakout" nuclear weapons threat, then such a thunderbolt might be quite likely-but would it be legal?129

Sometimes, a state may satisfy the traditional jus ad bellum criteria for a valid exercise of military force in "self-defense" if it is, due to the constellation of political and military factors, particularly aggrieved or particularly jeopardized by another's violation. That is, under certain factual circumstances-especially when dealing with the ultimate power of nuclear weapons-a state might perceive that the crucible of "necessity" had arrived, and that if it does not act immediately to interdict the emerging threat, it may soon be too late, and the treaty violator will have succeeded in achieving an irreversible, militarily-significant one-sided nuclear weapons advantage. ${ }^{130}$

But perhaps not. The traditional international law Caroline requirement of "necessity" for justifying an attack has some serious teeth--the rhetoric that the threat must be "instant, overwhelming, and leaving no choice of means and no moment for deliberation"131 is not lightly disregarded. At the moment a treaty violation is discovered, it may not yet be clear (and may not be provable on the basis of persuasive, unclassified information that the discoverer is willing to present in public) how far along the

127. See Int'l L. Comm'n, Draft Articles, supra note 16, arts. 22, 50 (discussing the validity of "countermeasures").

128. See Christopher Ford, Nuclear Weapons Reconstitution and its Discontents: Challenges of "Weaponless Deterrence", in Deterrence: Its Past and Future, supra note 116, at 131-215; Taubman, supra note 107, at 362-63; End-State Issues, supra note 104, at 32-34; Steven Pifer \& Michael E. O'Hanlon, The Opportunity: Next Steps in Reducing Nuclear Arms 191-97 (2012); Debate, supra note 104 , at $120-22$.

129. See David Holloway, Deterrence and Enforcement in a World Free of Nuclear Weapons, in DETERrence: Its PAST AND Future, supra noce 116, at 335-71; Barry M. Blechman, Why We Need to Eliminate Nuclear Weapons - And How to Do $I t$, in Elements of a Nuclear Disarmament Treaty $1,17-18$ (Barry M. Blechman \& Alexander K. Bollfrass eds., 2010).

130. See Int'l L. Comm'n, Draft Articles, supra note 16, at 80-84 (discussing the concept of "necessity" as a justification for otherwise-illegal state action).

131. Avalon Project, supra note 18. 
cheater's weapons development program has already proceeded; whether that state is irrevocably committed to that unfortunate course of action; on what timetable a nuclear weapon (or the several such devices that might be necessary in order to establish a meaningful military capability) might be produced; how likely it is that the weapon(s), when available, would actually be brandished or used in conflict; what country or countries might be the plausible target of the violator; and whether responses other than a preemptive military strike could still suffice to avert the Armageddon. ${ }^{132}$

The concept of "anticipatory self-defense," authorizing an about-to-beattacked state to strike first, to blunt the projected onslaught, instead of sitting passively and absorbing the aggressor's initial barrage, is of contested validity under the UN Charter. ${ }^{133}$ Some have argued that in the era of modern weapons of mass destruction, the authorization to pre-empt an incipient attack should be preserved and even expanded. They maintain that the moment of "last clear chance" to avoid nuclear warfare should be pushed earlier, since the adverse consequences of waiting too long could be fatal. ${ }^{134}$

But sometimes, even a serious violation of the Zero Treaty might not legally amount to an "imminent" threat to any particular country. The breach may be important and may demand a concerted, emphatic response, but it might not translate into a precipitous danger that the illegal nuclear weapons under development will very soon be used against a specific innocent state or its allies. The doctrine of self-defense, even with its "anticipatory" variant, is not infinitely elastic. ${ }^{135}$

One admittedly incomplete analogy arises from Israel's 1981 bombing of the Osiraq nuclear reactor then under construction outside Baghdad. Iraq (and France, which had supplied the facility) maintained that the site was intended only for peaceful purposes and would be subject to international safeguards. Israel, however, apprehended that the plutonium generated in the facility would be diverted into a weapons program that would, sooner or

132. Cf. Franck, Who Killed, supra note 17, at 816-71 (noting the difficulty of applying art. 51 in factually contested situations); Int'l L. Comm'n, Draft Articles, supra note 16, at 126, 137 (discussing the invocation of rights by one state on behalf of another state, when the primary actor is not itself directly jeopardized); Charles J. Dunlap, Jr., Is the Military Option to Strike Iran (Legally) on the Table?, THE HILt (July 6, 2015, 6:30 AM), http://thehill.com/blogs/pundits-blog/defense/246900-is-the-military-option-to-strike-iran-legally-on-the-table [https://perma.cc/2FEX-AGP2] (discussing international law restraints against a pre-emptive military strike, even when the targeted state is illegally developing nuclear weapons); Arimatsu \& Schmitt, supra note 17, at 16-19 (discussing the criteria for an exercise of legitimate anticipatory self-defense); DeBATE, supra note 104, at 102 (evaluating whether violation of a Zero Treaty would constitute an "existential threat").

133. See supra text accompanying note 132 (discussing that some authorities maintain that "if an armed attack occurs" means "only if").

134. See supra text accompanying note 19 (quoting Bush Administration's rhetoric on not letting the smoking gun be a mushroom cloud).

135. High-Level Panel, supra note 19, at 63 (arguing that "in a world full of perceived potential threats," permitting unilateral preventive war without endorsement by the Security Council would be too risky because "[a]llowing one to so act is to allow all"). 
later, target Israel. Israel's surprise aerial attack dexterously destroyed the facility shortly before it would have become operational; estimates differ about whether successful functioning of the plant could have enabled Iraq to construct a nuclear weapon within a year or two, or only within a much longer time horizon. ${ }^{136}$

In any event, the world (including the United States) strongly condemned the Israeli attack as a violation of the Charter, with both the Security Council ${ }^{137}$ and the General Assembly ${ }^{138}$ adopting sharply-worded resolutions. The legal analysis underlying these criticisms sounded in "necessity"--the argument that Israel was not facing an "imminent" threat, because plenty of time was still available for pursuit of a diplomatic solution. Subsequent developments regarding Saddam Hussein's weapons of mass destruction programs cloud any clear "lessons" from the incident, ${ }^{139}$ but the principles from the ancient Caroline case ${ }^{140}$ remain intact. ${ }^{141}$

If this type of national self-help, in initiating unilateral military force to redress a serious (but not yet imminent) danger may be legally unavailable, and if the Security Council might be debilitated, due to the threat or exercise of the veto, to deal dispositively with this "threat to the peace," what can parties to the Zero Treaty legitimately do?

Contracting Around the Security Council. The portrait here (again, parallel to that adduced supra for an $\mathrm{R} 2 \mathrm{P}$ Treaty ${ }^{142}$ ), contemplates the parties to a Zero Treaty finessing the Charter and bypassing the P5 veto. The treaty negotiators would include, as a central enforcement feature in the contemplated Zero Treaty, an explicit delegation, to a new international organization cre-

136. McCormack, supra note 17, at 159-63; Anthony D'Amato, Israel's Air Strike Against the Osiraq Reactor: A Retrospective, 10 TeMP. InT'L \& Comp. L.J. 259 (1996); Osiraq / Tammuz I, Fed'N AM. SCIENTISTs, http://fas.org/nuke/guide/iraq/facility/osiraq.htm (last visited Mar. 4, 2016) thttps:/perma .cc/2DLR-AUD6]; Peter S. Ford, U.S. Air Force InSt. for Nat'l Sec. Studies, Israel's Attack on Osiraq: A Model for Future Preventive Strikes? (2005), http://www.usafa.edu/df/inss/OCP/ ocp59.pdf [https://perma.cc/5Y8F-EP6T]; W. Michael Reisman, Assessing Claims to Revise the Laws of War, 97 AM. J. INT'L. L. 82, 82-90 (2003).

137. S.C. Res. 487 (June 19, 1981) (adopted unanimously); McCormaCK, supra note 17, at 23-37 (discussing resolution 487).

138. G.A. Res. 36/27 (Nov. 13, 1981).

139. See Iraqi Nuclear Weapons, FED'N Am. ScienTisTs, http://fas.org/nuke/guide/iraq/nuke/program htm (last visited Mar. 4, 2016) [https://perma.cc/6EMP-4RTL]; Saddam Hussein's Weapons of Mass Destruction, PBS FRONTLINE, htcp:/www.pbs.org/wgbh/pages/frontline/shows/gunning/etc/arsenal.html (last visited Mar. 4, 2016) [https://perma.cc/6VWN-8JKH].

140. Supra note 18.

141. In 2007, Israel mounted a similar attack destroying a clandestine nuclear reactor under construction in Syria that Israel feared might be the basis for a nuclear weapons program that would be targeted against Israel. In this instance, there was much less global adverse political and legal reaction, in part because of the intense secrecy that both Syria and Israel imposed. See Leonard S. Spector \& Avner Cohen, Israel's Airstrike on Syria's Reactor: Implications for the Nonproliferation Regime, 38 ARMS CONTROL TODAY, July-Aug. 2008, at 15, http://www.armscontrol.org/act/2008_07-08/SpectorCohen [https:// perma.cc/K44V-AJTH]; David E. Sanger and Mark Mazzetti, Israel Struck Syrian Nuclear Project, Analysts Say, N.Y. Times (Oct. 14, 2007), http://www.nytimes.com/2007/10/14/washington/14weapons .html [https://perma.cc/6KGR-WRDQ].

142. Supra text accompanying notes 89-97. 
ated by the instrument, of the power to authorize the use of military force to redress serious treaty violations. This treaty organ would have to include all the P5 members, and they would probably naturally lead it, as the most prominent military and political powers of the day; but no single P5 member would enjoy the unilateral power to abort decisions reached by the rest of the members. Possible details for such a scheme are presented in the next Part of this Article.

There are other potential routes to a similar outcome. The P5 could agree (formally or informally) not to exercise their Security Council veto powers so often, confining themselves to a measure of reciprocal self-restraint in matters arising under the R2P Treaty or the Zero Treaty. Alternatively, parties could amend the Charter, to dilute the Security Council veto power, such as by specifying that two, rather than just one, of the P5 would be required to block a resolution. They could also create a new body inside the UN structure delegated to authorize and supervise certain kinds of military operations in cases of Security Council paralysis. ${ }^{143}$ But none of these options is now on the horizon, so this Article addresses a different kind of route: the creation, by treaty (or treaties) of a new dedicated, consent-based, non-veto-bound, international military authority.

\section{Part IV: A Treaty-Based Consent Regime for Authorizing Military Force}

This Part of the Article brainstorms possibilities for an R2P Treaty and/ or a Zero Treaty that would depart from the dictates of the Security Council by creating their own mechanisms for authorizing military force, based on the consent of the countries negotiating and joining the agreement.

Institutional Design. The drafters of an ambitious new human rights or disarmament treaty will have to resolve numerous intricate and interwoven questions. At present, the best we can do is to speculate about some of the

143. Butler, supra note 32, at 35-37 (highlighting the need to reform Security Council membership and procedures to deal with the threat of nuclear weapons); Stewart M. Patrick, Limiting the Veto in Cases of Mass Atrocities: Is the Proposed Code of Conduct Workable?, Council on Foreign Rel. Uan. 21, 2015), http://www.cfr.org/france/limiting-veto-cases-mass-atrocities-proposed-code-conduct-workable/ p36019 [https://perma.cc/82GD-23VZ] (critiquing proposal by French President Francois Hollande for an informal, voluntary and collective agreement by the P5 to suspend their veto rights regarding Security Council resolutions that deal with mass atrocities); High-Level Panel, supra note 19, at 64 (arguing that if some favor an expansive national right to use military force because they lack confidence in the quality and objectivity of the Security Council's decision-making, the solution is to reform the Security Council, not to reduce its power); Russia Rejects Frencb Proposal to Limit UN Veto, Agence Frence Presse (Sept. 2, 2015, 3:44 PM), http://www.globalpost.com/article/6641390/2015/09/02/russia-rejectsfrench-proposal-limit-un-veto [https://perma.cc/5K4E-FUTM]; Carole Landry, Veto Under Fire as United Nations Turns 70, Armed Forces Press (Oct. 23, 2015, 5:05 PM), http://news.yahoo.com/veto-underfire-united-nations-turns-70-210559865.html [https://perma.cc/D6WR-Q98Z] (noting that 104 countries support proposed "code of conduct" for limiting use of veto, but Russia, China, and the United States resist it). 
necessary features, concentrating on the institutional arrangements for enforcement of compliance. ${ }^{144}$

At the outset, the treaty will, of course, have to specify the substantive obligations regarding human rights or disarmament, and establish a suitable monitoring, reporting, or verification apparatus to oversee compliance--likely a far more rigorous and intrusive regimen for the Zero Treaty than for the R2P Treaty. ${ }^{145}$ The treaty makers will decide whether to allow, limit, or prohibit reservations, ${ }^{146}$ and whether to permit denunciation or withdrawal for "supreme national interests" and/or temporary derogations in emergency circumstances. ${ }^{147}$ The treaty will likely create a new organization (or perhaps piggyback onto an existing institurion ${ }^{148}$ ) tasked, inter alia, to operate the verification algorithms, resolve ambiguities, clarify information (publicly or confidentially), and reconcile disputes about compliance. ${ }^{149}$ There could be multiple tracks or tiers calibrating these mandatory exchanges between contentious parties, including the possibility of referral to extramural institutions such as the International Court of Justice. ${ }^{150}$

The new organization would be empowered to pursue treaty enforcement via non-military means, where diplomacy, economic sanctions and other remedies were promising. Like the Security Council, the R2P Treaty or Zero Treaty organization would plausibly seek to exhaust non-violent options before escalating, but if it were clear that the lesser methods would be

144. See Nuclear Weapons Convention, supra note 115 ; Koplow, supra note 115, at 186.

145. For examples of verification provisions of arms control treaties, see CWC, supra note 123 , Annex on Implementation and Verification; CTBT, supra note 123, Protocol.

146. A reservation is a unilateral statement whereby a state purports to exclude or modify the legal effect of certain provisions of the treaty in their application to that state. See VCLT, supra note 61, art. 2(d); Restatement, supra note 62, § 313; Edward T. Swaine, Treaty Reservations, in The OXFORD Guide to Treaties 277, 277 (Duncan B. Hollis ed., 2012). Arms control treaties tend to be restrictive of reservations. See, e.g., CWC, supra note 123, art. XXII; CTBT, stpra note 123, art. XV. In contrast, human rights treaties tend to be permissive of reservations. See, e.g., ICCPR, stupra note 42 (containing no provision restricting reservations and including multiple reservations); U.N. Treaty Collection, supra note 47.

147. Arms control treaties usually explicitly allow withdrawal, which has been rare, and human rights treaties sometimes permit withdrawal and frequencly tolerate temporary derogations. See supra text accompanying note 67. See generally, Laurence R. Helfer, Terminating Treaties, in The Oxford Guide to Treatues 634, 634 (Duncan B. Hollis ed., 2012).

148. For example, the International Atomic Energy Agency predates the NPT, but is now responsible for many aspects of its implementarion. See Treaty on the Non-Proliferation of Nuclear Weapons (NPT), INT'L ATOMIC ENERGY AGENCY, https://www.iaea.org/publications/documents/treaties/npt thttps:/per ma.cc/RL7S-EBQ8] (last visited Mar. 5, 2016); Thomas E. Shea, The Role of the IAEA in a World Reducing Stocks of Nuclear Weapons, in Cultivating Confidence: Verification, Monitoring, and EN. forcement for a World Free or Nuclear Weapons 229, 229-31 (Corey Hinderstein ed., 2010).

149. For organizations in arms control treaties, see CWC, supra note 123 , art. VIII (establishing the Organization for the Prohibition of Chemical Weapons); CTBT, supra note 123, art. II (creating the Comprehensive Nuclear Test-Ban Treaty Organization). For organizations in human rights treaties, see supra text accompanying note 46 (discussing treary monitoring bodies).

150. CWC, supra note 124, art. XIV.2 (regarding possible referral of disputes to ICJ); CTBT, supra note 123, art. VI.2, 5; see also Richard B. Bilder, Judicial Procedures Relating to the Use of Force, in LAw and Force in the New International Order 269 (Lori Fisler Damrosch \& David J. Scheffer eds., 1991) (evaluating skeprically the utility of judicial procedures for resolving disputes concerning states' use of military force). 
futile, they could be disregarded. Especially concerning the ultimate fallback option, the use of military force, a Zero Treaty or R2P Treaty would plausibly preserve the Security Council's "primary responsibility"151 for any enforcement action, but we now posit the creation of a complementary alternative mechanism to steam to the rescue when the threat or use of the veto ties the P5 into inextricable knots. ${ }^{152}$

There are multiple options for structuring this new power. A use of force might be authorized by the treaty's full membership (voting in an all-inclusive assembly of the states parties ${ }^{153}$ ) or perhaps by a more exclusive leadership club (typically designated as an "executive council" of a few dozen members ${ }^{154}$ ). The endorsement might require only a simple majority vote, but more likely some degree of supermajority-but it would not require consensus or unanimity, and would not afford any single state the unyielding power to block action. ${ }^{155}$ In some treaties, there is a "red light/green light" question-i.e., whether a proposed action (such as a "challenge" onsite inspection, in cases of suspected non-compliance ${ }^{156}$ ) can proceed automatically unless the specified decision-making body affirmatively blocks it (by a negative vote that illuminates a "red stop light") or cannot be undertaken unless the controllers affirmatively endorse it (through a positive "green light" vote). ${ }^{157}$ There are also questions about the speed of a response-how quickly can (and must) the appropriate body convene to address and decide a question about the use of force in reaction to a

151. U.N. Charter art. 24, II 1 ; see also CWC, supra note 123 , art. XII.4 (referring possibly to the United Nations of compliance issues of "particular gravity"); CTBT, supra note 123, art. V.4.

152. See generally Wippman, Treaty-Based, supra note 93, at 654 (discussing the dangers and advantages of treaties authorizing military action, which might threaren to usurp the authority of the Security Council; noting that the first responsibility for responding to threats to the peace should continue to reside in the Security Council).

153. See CWC, supra note 123 , art. VIII.B; CTBT, supra note 123, art. II.B.

154. See CWC, supra note 123, arc. VIII.C; CTBT, supra note 123, art. II.C.

155. CWC, supra note 123, art. IX.17 (specifying that the Executive Council may decide by a three-quarter majority vote to cancel a requested on-site inspection); CTBT, supra note 123, art. IV.46 (requiring thirty affirmative votes among the fifty-one members of the Executive Council to authorize a requested on-site inspection); see Walter Krutzsch \& Ralf Trapp, A Commentary on the Chemical Weapons Convention 189 (1994) (describing the mechanism for requesting and cancelling on-site inspections); Eric A. Posner \& Alan O. Sykes, Voting Rules in International Organizations, 15 CHI. J. INT'L L. 195, 197-205 (2014) (surveying majority and supermajority voting requirements in various international organizations); Hathaway, Consent-Based, supra note 12, at 564-65; Harrell, supra nore 28, at 444. As a further safeguard, the Zero Treaty or R2P Treary could specify that the majority or supermajority required to authorize a use of military force must be "qualified" in some special way, such as by including most of the states in the relevant geographical region or the states with the biggest potential interest in the issue. See also U.N. Charter ch. VI (specifying that when the Security Council acts under Chapter VI of the Charter that deals with non-military measures for pacific settlement of disputes, any state that is a party to the dispute shall abstain from voting on any resolution regarding it).

156. A "challenge inspection" is an on-site visit, conducted by designated personnel from the international organization, to determine whether there has been a violation of the terms of the treaty. See CWC, supra note 123, art. IX.8-25; CTBT, supra note 123, art. IV.56-67.

157. Compare CWC, supra note 123, art. IX.17 (regarding a red light system), with CTBT, supra note 123, art. IV.46 (regarding green light); Muller, Enforcement of the Rules in a Nuclear Weapon-Free World, supra note 116 , at $45-47$. 
violation. ${ }^{158}$ For present purposes, we set aside other important implementing variables such as who would actually undertake a military operation endorsed to enforce the treaty, and how the financial costs of the campaign would be borne.

The new treaty organization could exercise its enhanced enforcement powers only against states that had voluntarily elected to join the relevant R2P or Zero treaty. The problem of "holdout" countries who resist assuming the legal obligations would still have to be dealt with by the Security Council or by the affected community of nations more generally, much as it is today. But, as discussed infra, there could not realistically be many strident naysayers for a Zero Treaty to be brought into force.

Any use of military force in these scenarios would be governed by the whole corpus of humanitarian law, jus in bello, including the constraints of discrimination, necessity, proportionality, and the avoidance of unnecessary suffering. ${ }^{159}$ In particular, the operation would be defined in scope and duration by the "object and purpose" of the relevant treaty, ${ }^{160}$ and could not validly be expanded into more grandiose "regime change" or other pretextual ultra vires goals. ${ }^{161}$ "Mission creep" would not be permitted; international enforcement troops could not overstay their valid objective or morph into a continued occupation force. ${ }^{162}$ In a phrase adapted from the Caroline text, the military action is defined by the necessity of treaty enforcement and kept clearly within it. ${ }^{163}$

158. See CWC, supra note 123, art. IX.15, 17, Verification Annex Part X.39 (specifying deadlines for each step in authorizing an inspection); CTBT, supra note 123, art. IV.46-52.

159. U.S. Dep't of Defense, Department of Defense Law of War Manual (2015), http:// www.defense.gov/Portals/1/Documents/pubs/Law-of-War-Manual-June-2015.pdf [https://perma.cc/ 6AZC-RNS4]; Gary D. Solis, The Law of Armed Conflict: International. Humanitarian Law in War 250-85 (2010); Hilaire McCoubrey \& Nigel D. White, International Law and Armed CONFLict 189-345 (1992).

160. See VCLT, supra note 61 , art. 31.1 (stating that a treaty is to be interpreted in good faith, in light of its object and purpose).

161. Komp, supra note 81 , at 16-21 (analyzing the intentions of the states intervening in Libya); Rieff, supra note 81 .

162. Even if foreign military forces have a legal basis for their initial presence in a country (such as consent of the host state), they violate international legal standards if they stay beyond the permitted duration or undertake activities outside the authorized scope. G.A. Res. 3314, art. 3(e) (Dec. 14, 1974); Bílková, supra note 87, at 32 (discussing continued presence of Russian troops in Ukraine-even if the foreign forces were originally deployed there by consent, their failure to withdraw when requested is a violation of international law); Yoram Dinstein, WAR, AGgression and Self-Defence 121-23 (5th ed. 2012); Lieblich, stipra note 15, at 364 (asserting that even if a state initially consents to another state's military presence in its territory, when that consent is withdrawn, any continued military presence constitutes aggression); see Armed Activities on the Territory of the Congo (Dem. Rep. Congo vs. Uganda), Judgement, 2005 I.C.J. Rep. 168, \$ 42-54 (Dec. 19, 2005) (considering the duration and withdrawal of Congo's consent for Ugandan military forces to be present on its territory).

163. See Avalon Project, supra note 18 (providing the letter from Daniel Webster to Lord Ashburton, April 24, 1841, asserting what has come to be known as the proportionality rule for actions undertaken in self-defense: the actor must do "nothing unreasonable or excessive; since the act justified by the necessity of self-defence, must be limited by that necessity, and kept clearly within it"); Cohan, supra note 17 , at 341-45 (discussing proportionality and the goal of regime change); Brownlie, supra note 88 , at $261-64$. 
Problem 1: Article 103. The first legal impediment to the concept of circumventing the Security Council is posed by Article 103 of the Charter, which specifies unequivocally that "In the event of a conflict between the obligations of the Members of the United Nations under the present Charter and their obligations under any other international agreement, their obligations under the present Charter shall prevail."164 A Zero Treaty or R2P Treaty that asserted a new, third basis for the legal use of military force (in addition to the two Charter-established justifications of self-defense and Security Council authorization discussed supra ${ }^{165}$ ) would collide with this limitation.

Article 103 is an extraordinary provision. As the VCLT makes clear, the standard rule is that as between parties to successive multilateral instruments dealing with the same subject matter, the newest document will ordinarily prevail. ${ }^{166}$ But even in the VCLT, Article 103 of the Charter is called out as the single exception to that practice. ${ }^{167}$

This pattern is designed to accord the Charter a unique "constitutional" status in international law, superior to other prescriptive processes, permanently preserving the primacy of the Security Council and the special role of the P5 as supreme guardians of international peace and security. ${ }^{168}$ The drafters of the Charter wanted to entrench it deeply in international law, surpassing the efforts of any subsequent lawmakers, even on issues such as human rights and disarmament.

It may now be debated whether Article 103 is truly binding. Perhaps in the untrammeled exercise of their sovereignty, states could still validly conclude a new treaty and specify that it would govern their relations inter se, "notwithstanding" any conflict with the Charter (or perhaps states could accomplish a similar objective only via amendment to the Charter). For present purposes, however, the simpler and more compelling argument, pursued infra, is to contend that the contemplated provisions of the R2P Treaty or Zero Treaty are not truly in "conflict" with the Charter, so Article 103 is not implicated. ${ }^{169}$

Problem 2: Jus Cogens. Beyond the text of Article 103 lurks a related concept, the notion that Article 2(4) (and perhaps Article 2(7), as well) of the

164. U.N. Charter art. 103.

165. See supra text accompanying note 152 (regarding jus ad bellum justifications).

166. VCLT, supra note 61, art. 30; RESTATEMENT, supra note 62, \$323; Richard D. Kearney \& Robert E. Dalton, The Treaty on Treaties, 64 AM. J. INT'L L. 495, 517-18 (1970).

167. VCLT, supra note 61 , art. 30.1 ; see RESTATEMENT, supra note $62, \S 323 \mathrm{cmt}$. b; Hurd, supra note 23, at 13 (considering ICJ attitude toward art. 103); Hurd, supra note 23, at 14 (discussing European Court of Justice approach to art. 103).

168. W. Michael Reisman, Termination of the USSR's Treaty Right of Intervention in Iran, 74 AM. J. INT'L L. 134, 150-51 (1980) [hereinafter Reisman, Termination]; Wippman, Treaty-Based, supra note 93, at 620 (noring that under arr. 103, any treaty would be void if it conflicts with art. 2(4)); Bardo Fassbender, The United Nations Chatter as Constitution of the International Community, 36 Colum. J. TransNat'l L. 529, 577-78 (1998).

169. Infra discussion accompanying notes 207-16. 
Charter constitute rules of $j u s$ cogens, peremptory norms of international law from which no derogation is permitted. ${ }^{170}$ The doctrine of jus cogens is not well worked out as a jurisprudential matter, and some authorities continue to deny its existence or at least its primacy; the International Court of Justice has never had the occasion to interpret or apply the principle in any detail. ${ }^{171}$ Nonetheless, the VCLT is quite definitive in mandating that any treaty provision that conflicts with a norm of $j u s$ cogens is void ${ }^{172}$ and that states are inherently obligated to "eliminate as far as possible the consequences of any act performed in reliance upon" a treaty provision that violates jus cogens. ${ }^{173}$

There is no authoritative list of state actions or policies that contravene jus cogens; the most frequently invoked illustrations include slavery, genocide, apartheid, and piracy. ${ }^{174}$ An agreement to derogate from Article 2(4) of the Charter, too, would assuredly be widely deemed incompatible with jus cogens, so any treaty that transgressed that provision would be void. ${ }^{175}$ The enforcement mechanism for a new treaty would therefore not be allowed to usurp the authority of Article 2(4) in a manner that violates jus cogens.

It is conceivable that the contemplated new R2P Treaty or Zero Treaty could itself be deemed to express a newly emerging norm of jus cogens, trumping Article 2(4). Indeed, the VCLT explicitly contemplates the pros-

170. VCLT, supra note 61 , art. 53 (defining jus cogens as "a norm accepted and recognized by the international community of States as a whole as norm from which no derogation is permitted"); RESTAtement, supra note $62, \S 102 \mathrm{cmt}$. k, sec. $331.2(\mathrm{~b})$, sec. 702; Int'l L. Comm'n, Draft Articles, supra note 16, at 84-85; Int'l Law Comm'n, Report of the International Law Commission: Sixty-sixth Session, U.N. Doc. A/69/10, annex (2014) thereinafter ILC Report] (describing new ILC project to study jus cogens); Kearney \& Dalton, supra note 166, at 535-38; Alexander Orakhelashvili, Changing Jus Cogens Through State Practice? The Case of the Probibition of the Use of Force and Its Exceptions, in THE OXFORD Handbook of the Use of Force in International Law 157 (Marc Wellet ed., 2015); André de Hoogh, Jus Cogens and the $U_{s e}$ of Armed Force, in THE OXford HandBoOK OF THE USE OF Force IN International Law 1161 (Marc Weller ed., 2015); Evan J. Criddle \& Evan Fox-Decent, A Fiduciary Theory of Jus Cogens, 34 YALE J. INT'L L. 331, 331-39 (2009).

171. ILC Report, supra note 170, paras. 3, 6, 11; Criddle \& Fox-Decent, supra note 170, at 345-46 (concluding that jus cogens "remains a popular concept in search of a viable theory," with few real-world applications); Andrea Bianchi, Human Rights and the Magic of Jus Cogens, 19 EUR. J. INT'L L., 491, 501-05 (2008) (noting how the ICJ has occasionally discussed juts cogens, but never made it the basis for a decision); Jan Klabbers, The Validity and Invalidity of Treaties, in The Oxford Guide to Treaties $551,570-74$ (Duncan B. Hollis ed., 2012).

172. VCLT, supra note 61 , arts. 53,64

173. VCLT, supra note 61, art. 71; Int'l L. Comm'n, Draft Articles, stupra note 16, at 113-16 (discussing states' obligation to oppose violations of peremptory norms).

174. Int'1 L. Comm 'n, Draft Articles, supra note 16, at 84-85, 112-13; Criddle \& Fox-Decent, supra note 170 , at $368-70$; Bianchi, supra note 171 , at $492-95$.

175. Henkin, Gross Violation, supra note 12, at 309 (asserting that Article 2(4) of the Charter is jus cogens); Harrell, supra note 28, at 430; Reisman, Termination, supra note 168, at 151-53; Wippman, Treaty-Based, supra note 93 , at 619 (concluding that the exact content of jus cogens is unclear, but "at a minimum the prohibition on the use of force embodied in Article 2(4) of the UN Charter is widely accepted as such a norm"); Int'l L. Comm'n, Draft Articles, supra note 16, at 85, 112; Fassbender, supra note 168, at 591; Military and Paramilitary Activities in and Against Nicaragua (Nicar. v. U.S.), Judgement, 1986 I.C.J. 14, \190 (June 27) (showing that ICJ considers whether Article 2(4) constitutes jus cogens). 
pect that new peremptory norms could arise and supersede their forebears. ${ }^{176}$ But the more functional argument here, presented in the next section, would be to assert that the enforcement provisions of the new agreements do not quite "conflict" with a jus cogens norm even though the deviation from the concepts underlying Article 2(4) seems apparent. ${ }^{177}$

The Concept of State Consent. The essential "escape hatch" from these twin problems therefore lies in the notion of consent. State consent is woven tightly into the DNA of modern international law; for better or worse, the Westphalian apparatus empowers each country either voluntarily agree to be bound by any rule of international law or to withhold its support and basically escape the constraints. ${ }^{178}$ In particular, a state is ordinarily free to arm itself as it likes, even if its neighbors find that behavior obnoxious and threatening, unless it has consented to some form of restriction. ${ }^{179}$ Likewise, many aspects of a state's internal functioning-for example, its dealing with civil and political rights concerning property, voting, religion, and other key practices-are widely regarded as being fundamentally of domestic relevance, unless they fall so far beneath international human rights standards as to generate outside indignation. ${ }^{180}$

Moreover, consent cures many ills-a state may waive its objection to injuries committed against it. As the International Law Commission states, "valid consent by a State to the commission of a given act by another State precludes the wrongfulness of that act in relation to the former State."181 But may a state validly and irrevocably consent, in advance, to a future use

176. VCLT, supra note 61, art. 64; Criddle \& Fox-Decent, supra note 170, at 370-75 (discussing emerging jus cogens norms).

177. But see Ratner, supra note 80 , at 294 (asking whether the pattern of state practice in undertaking and in declining to criticize military interventions in support of fundamental human rights even without authorization of the Security Council constitutes a de facto revision of the black letter international norm).

178. Int'l L. Comm'n, Draft Articles, supra note 16, at 72-74; Wippman, Military Intervention, supra note 28, at 209 (stressing the importance of consent as a justification for the use of military force); Thomas \& Thomas, supra note 14, at 91-97; Brownlie, supra note 17, at 317-27; Nico Krisch, Tbe Decay of Consent: International Law in an Age of Global Public Goods, 108 AM. J. OF INT'L L. 1, 2, 26 (2014); Ashley S. Deeks, Consent to the Use of Force and International Law Supremacy, 54 Harv. INT'L L. J. 1, 8-27 (2013); Hathaway, Consent-Based, supra note 12, at 613 (noting numerous pre-1945 treaties that authorized uses of military force).

179. Military and Paramilitary Activities in and Against Nicaragua, 1986 I.C.J. 14, If 269 ("[I]ח international law there are no rules, other than such rules as may be accepted by the State concerned, by treaty or otherwise, whereby the level of armaments of a sovereign State can be limited."); Quincy Wright, The Cuban Quarantine, 57 AM. J. INT'L L. 546, 550-51 (1963) (evaluating the Soviet Union's covert introduction of offensive nuclear weapons into Cuba in 1962 and concluding that international law imposes no general obligations limiting a state's ability to arm itself, to assist others in armaments, to procure patently offensive weaponry, and to do so in secret).

180. Thomas M. Franck, Intervention Against Illegitimate Regimes, in Law and ForCE IN THE New International Order 159, 169 (Lori F. Damrosch \& David J. Scheffer eds., 1991) (noting that international law perceives all states as equals, but the Charter has nonetheless been used to exclude certain pariah states because of their failure to accord basic human rights); Levitt, supra note 90 , at 792-94 (noting that where intervention is based on prior consent of the state, it does not raise the same legal barriers).

181. Int'l L. Comm'n, Draft Articles, supra note 16, at 72. 
of military force against itself, allowing outsiders to enforce an R2P Treaty or a Zero Treaty, in circumstances that would otherwise constitute a violation of Article 2(4) and jus cogens? 182

Long and broad international practice pursuant to a general "freedom to contract" model of international law has validated that a state may indeed unilaterally decide to accept a great many restrictions and inhibitions upon its sovereignty that could not legitimately be forced upon it. ${ }^{183}$ For example, a state may voluntarily:

- surrender all claims to certain of its land and maritime areas in perpetuity, such as via a negotiated permanent settlement of a border dispute with a neighbor, ${ }^{184}$ or via submission of the controversy to an international adjudicator (as Costa Rica and Nicaragua, ${ }^{185}$ and Burkina Faso and Niger ${ }^{186}$ have contemporaneously done in the ICJ), while without state consent, severing any slice of land would ordinarily be a violation of its "territorial integrity"; 187

- extinguish its sovereignty entirely, such as by voluntarily merging itself into some other state (as East Germany ceased to exist when it became

182. Nore that this Arricle uses the concept of "consent" in a special way here. Most often, consent refers to a state $\mathrm{X}$ requesting or inviting another state $\mathrm{Y}$ to send forces into $\mathrm{X}$ or to assist $\mathrm{X}$ in responding to threatened or actual external aggression or internal disruption. In that situation, consent is a full justification for $\mathrm{Y}$ to be present and to conduct military operations inside $\mathrm{X}$ alongside $\mathrm{X}$ 's own forces (as long as $\mathrm{Y}$ stays inside the scope of the permission granted). Here, in contrast, we are contemplating $\mathrm{X}$ giving $\mathrm{Y}$ permission to use force against $\mathrm{X}$ itself, not just inside $\mathrm{X}$ 's territory. The concept of $\mathrm{X}$ agreeing to a use of force against itself may seem almost incoherent - if $X$ consents, then $X$ should nor be fighting back against $Y$, so there should be no need to use force. But it is the passage of time that gives the concept meaning: If $\mathrm{X}$ consents now to a use of force by $\mathrm{Y}$ at some point in the future, such as against a successor government of $\mathrm{X}$, then the issue is the continuing validity of $\mathrm{X}$ 's initial grant of consent. See Bílková, supra note 87, at 40-42 (discussing legitimacy of Ukrainian officials' invitations to Russian forces to enter the country during the 2014 disruptions); Farer, Gilarantor of Democracy, supra. note 14, at 162-64; Wippman, Treaty-Based, supra note 93, at 620-22; Int'l L. Comm'n, Draft Articles, supra note 16, at 73, para. 4; Thomas \& Thomas, supra note 14, at 91-97 (discussing importance of consent); Deeks, supra note 178.

183. Wippman, Treaty-Based, supra note 93, at 635 (noting the importance and the difficulty of differentiating between unlawful coercion of a state (which may invalidate its consent to a treaty) and permissible political or economic pressure (which does not negate consent)); Farer, Guarantor of Democracy, supra noce 14, at 168; VCLT, supra note 61 , art. 52 (prescribing that a treaty is void if it has been procured via a threat of force in violation of the Charter); Fox, stpra note 90, at 831-33 (describing two polar opposite positions regarding validity of "pro-invasion pacts"); Winfield, supra note 14, at 155 ; Justin A. Evison, MIGS and Monks in Crimed: Russia Flexes Cultural and Military Muscles, Revealing Dire Need for Balance of Uti Possidetis and Internationally Recognized Self-Determination, 220 MiL. L. REv. 90 (2014) (noting that the doctrine of uti possidetis asserts that colonial borders are permanent, applying even after the colony becomes independent).

184. See Syed Zain al-Mahmoad, India, Bangladesh Swap Land Near Their Border, Wall. ST. J. (July 31, 2015), http://blogs.wsj.com/indiarealtime/2015/08/03/india-bangladesh-swap-land-near-their-border/ [https://perma.cc/ZJM9-599D] (explaining that India and Bangladesh resolved longstanding border dispuces by exchanging small enclaves of land via negotiation).

185. Maritime Delimitation in the Caribbean Sea and the Pacific Ocean (Costa Rica v. Nicar.), Order, 2014 I.C.J. 461 (Apr. 1).

186. Seising the International Court of Justice of the Boundary Dispute Between Burkina Faso and the Republic of Niger (Burk. Faso/Niger), Special Agreement (July 20, 2010), http://www.icj-cij.org/ docket/index.php?p1 = 3\&p2 =3\&code $=$ bfn\&case $=149 \& \mathrm{k}=\mathrm{f} 9 \& \mathrm{p} 3=0$ [https: $/ /$ perma.cc $/ 4 \mathrm{CAG}-98 \mathrm{DN}]$.

187. U.N. Charter, art. 2, ๆ 4. 
part of the Federal Republic of Germany in $1990^{188}$ ), while without state consent, any such erasure of statehood would contravene the guarantee of "political independence"; 189

- turn over the conduct of its vital foreign affairs and self-defense policies to another state (as Liechtenstein has contracted with Switzerland, ${ }^{190}$ or as the United States has assumed those duties on behalf of former Pacific Trust Territories in Compacts of Free Association ${ }^{191}$ );

-allow intervention in its internal affairs, such as by joining human rights treaties that demand elevated standards and external monitoring for the treatment of the state's own citizens, ${ }^{192}$ in a manner that might otherwise contravene Article 2(7)'s non-intervention prohibitions; ${ }^{193}$

- limit its national security ability to defend itself, such as through arms control treaties that restrict the quantity and quality of specified armaments it may procure and wield in international armed conflict; ${ }^{194}$

- expose itself to intrusive inspection of its domestic territory, persons, papers, and facilities by foreign countries and organizations, in order to verify its compliance with arms control treaties; ${ }^{195}$

- restrict its future diplomatic and military maneuverability in international politics and security, such as by joining a durable treaty of alliance with other states, committing itself to a future use of force, or constraining itself to neutrality; ${ }^{196}$

188. Hubert Beemelmans, State Succession in International Law: Remarks on Recent Theory and State Praxis, 15 B.U. INT'L L. J. 71, 98-108 (1991) (examining the reunification of Germany); Uwe Hessler, The End of East Germany, Deutsche WeLle (Aug. 23, 2005), http://www.dw.com/en/the-end-of-eastgermany/a-1687204 [https://perma.cc/F9GX-J9KC]; see also JAMES P. JANKowski, NASSER's EgYPT, Arab National.tsm, and the United Arab Republic 101-13 (2002) (discussing the short-lived merger of Egypt and Syria into the United Arab Republic).

189. U.N. Charter, art. 2, If 4.

190. Principality of Liechtenstein, Switzerland, Federal. Department of Foreign Affairs, https://www.eda.admin.ch/eda/en/fdfa/foreign-policy/european-politics/liechtenstein.html (last visited Mar. 5, 2016) [htrps:/perma.cc/NN57-QAA8] (explaining that since Liechtenstein's request in 1919, Switzerland has assumed the role of safeguarding Liechtenstein's international interests, representing its citizens abroad, and operating common external borders).

191. See Carter \& Weiner, supra note 17, at 461-63 (describing how the United States retains major defense responsibilities for Palau, the Federated States of Micronesia, and the Republic of the Marshall Islands).

192. See supra notes 43-52 (citing human rights treaties); Military and Paramilitary Activities in and Against Nicaragua (Nicar. v. U. S.), Judgement, 1986 I.C.J. 14, ๆ 259 (June 27) (determining that a state can validly agree to a treaty provision requiring it to hold free and fair elections); Gaspare Genna \& Taeko Hiroi, Do Democracy Clauses Matter? The Effects of Regional Integration Associations on Political Stability and Democratic Consolidation (European Univ. Inst., Robert Schuman Ctr. for Advanced Stud., Working Paper No. 48, 2015) (analyzing the effects of regional treaties that require democracy in all member states).

193. U.N. Charter, art. 2, 17.

194. See, e.g., supra note 123 (citing treaty on chemical weapons).

195. See CWC, supra note 123, Verification Annex, pt. X; CTBT, supra note 123, Protocol, pt. II.

196. Wippman, Treaty-Based, supra note 14, at 617-18; The S.S. Wimbledon (Gr. Brit., Fr., It., Japan, and Pol. (intervening) v. Ger.), 1923 P.C.I.J. (ser. A) No. 1, at 25 (Aug. 17) (explaining that Germany had joined a treaty guaranteeing all states a permanent right of passage through the Kiel Canal and this obligation overrode Germany's obligations as a neutral in a subsequent wat between Russia and Poland). 
-invite another state to deploy military forces on its territory and to utilize those troops for specified purposes, and grant those foreign armies a substantial measure of extraterritorial jurisdiction for governing their own behavior; ${ }^{197}$ and

- submit itself to a substantial degree of outside governance, such as by joining the United Nations (and agreeing to accept and carry out decisions of the Security Council ${ }^{198}$ ), or by accepting the compulsory jurisdiction of the ICJ. ${ }^{199}$

A state may fine-tune these grants of consent, limiting them in scope, duration and content, ${ }^{200}$ but the point is that a state may freely exercise its sovereignty by voluntarily limiting or even surrendering that sovereignty. ${ }^{201}$

On the other hand, there are some actions concerning which a state may not provide valid consent under international law. ${ }^{202}$ As noted supra, the concept of jus cogens places some conceivable state operations outside the pale of international legitimacy. ${ }^{203}$ For example, States $X$ and $Y$ could not legally craft a treaty under which they agreed to permit the taking of each other's citizens (or citizens of state Z) as slaves. Nor could they validly undertake to jointly commit piracy, war crimes, or crimes against humanity, to initiate combined aggression against state $Z$ and carve up its territory between themselves. Similarly, international law would not allow states to suspend-generally or between themselves, for a short or long duration-the fundamental rules against torture or genocide, even if they were fully knowing and voluntary in purporting to do so. An agreement to shave away some of the sovereign protections of Article 2(4)-and especially to do so in perpetuity-may represent a limiting case of state freedom to contract. ${ }^{204}$

197. Hargrove, supra note 12, at 116; Lieblich, supra note 15, at 358-59 (discussing Status of Forces Agreements, pursuant to which the United States is authorized to base military forces in consenting states, and to exercise special jurisdictional powers over them).

198. See supra notes 23-24 (discussing the mandatory power of the Security Council).

199. U.N. Charter, art. 94 (establishing that UN member states undertake to comply with decisions of the ICJ). The ICJ can hear cases only concerning states that have agreed to accept its jurisdiction; an acceptance of "compulsory jurisdiction" is the broadest and most comprehensive form of doing so. See How the Court Works, Int'l Court of Justice, hrtp://www.icj-cij.org/court/index.php?pl= $1 \& \mathrm{p} 2=6$ (last visited Mar. 5, 2016) [https://perma.cc/7525-N5QQ].

200. See supra text accompanying note 163 (noting how the continued presence of foreign military forces, after the host state withdraws its consent, is a violation of international law).

201. See Harold H. Koh, Legal Advisor U.S. Dep't of State, Address at USCYBERCOM InterAgency Legal Conference (Sept. 18, 2012), http://www.state.gov/s/l/releases/remarks/197924.htm [https://perma.cc/RG9V-DJSW] (explaining that the US government sees international law not simply as a constraint, but as a set of "wise restraints that make us free"); Hathaway, International Delegation, supra note 67 , at 140-48 (arguing that state consent should be interpreted as an exercise of its sovereignty).

202. Farer, Guarantor of Democracy, supra note 14, at 168 (observing that "there are limits; there must be limits" to a government's ability to bind its successors); Wippman, Treaty-Based, supra note 93, at 611-12, 621-22.

203. See supra text accompanying notes 171-76.

204. Wippman, Treaty-Based, supra note 93, at 617 (arguing that the greater may not always include the lesser-that is, even if a state would be empowered to surrender its sovereigncy in toto, that 
So on which side of the line do we locate the contemplated Zero Treaty and R2P Treaty? Is the enforcement mechanism, through which each party would consent to a use of force against its future self, even in the absence of a Security Council resolution, a valid exercise of self-limiting sovereignty, or is it a contravention of the most fundamental international norms?

Parsing Article 2(4). The structure of Article 2(4) poses some complexity for this analysis. The single sentence of the provision may be parsed into three elements, the third of which further contains three sub-elements: All Members shall refrain in their international relations from (a) the threat or use of force (b) against (c1) the territorial integrity or (c2) political independence of any state, or (c3) in any other manner inconsistent with the Purposes of the United Nations. ${ }^{205}$

Here, element (a) is satisfied: we are contemplating that the international organization to be established by the R2P Treaty or Zero Treaty, and the states that are members of it, would be threatening or using force, as a last resort, to redress violations of the human rights and disarmament obligations.

However, the Zero Treaty and R2P Treaty proposals do not implicate element (b), because the contemplated exercise of force is not truly "against" the invaded state. That state has previously given its voluntary and knowing consent to the incursion action. By joining the treaty and accepting the indispensable enforcement mechanism, each party has reciprocally and irrevocably agreed to receive this form of coercion. Indeed, we can think of the state, when assuming these treaty commitments, as affirmatively requesting future outside military intervention, when necessary, to return the state to compliance and to divert it from the regrettable, temporary departure from its enduring human rights and disarmament aspirations. ${ }^{206}$

may not imply a legal ability to dispense with some of the protections of Article 2(4) until it ceases to be a state). Doswald-Beck, Legal Validity, supra note 14, at 246 (arguing that it is specious to contend that just because a state has the freedom to consent to extinguish its sovereignty, it should also have the right to consent to being invaded, because international law contains no norm against states merging, but it does contain a strong principle limiting the use of military force); Roth, Illegality, supra note 90 , at 330-31 (arguing that a greater power does not always include the lesser).

205. U.N. Charter, art. 2, 4; see Hathaway, Consent-Based, sttpra note 12, at 505 n.29; Wright, Cuban Quarantine, supra note 179, at 556-57 (assessing US actions during the 1962 Cuban Missile Crisis under the provisions of Article 2(4)); Brownlie, supra note 17, at 265-68 (parsing the negotiating and drafting history of Article 2(4)); McCoubrey and White, supra note 159, at 24-26 (concluding that the terms of Arricle 2(4) encompass "the totality of a state's sovereign rights"); Matthew A. Myers, Sr., Deterrence and the Threat of Force Ban: Does the UN Charter Probibit Some Military Exercises?, 162 MiL. L. Rev. 132, (1999); Oscar Schachter, International Law: The Right of States to Use Armed Force, 82 Mich. L. Rev. 1620, 1625-26 (1984) (construing the last twenty-three words of Article 2(4)); Tom Ruys, The Meaning of "Force" and the Boundaries of Jus Ad Bellum: Are "Minimal" Uses of Force Excluded from UN Charter 2(4), 108 Am. J. Of Int'l L. (2014); Anthony D'Amato, International Law: Process and Prospect 57-87 (1987).

206. Note that the issue explored here is quite different from the usual question about "consent" that sometimes arises in instances of foreign military intervention. That is, a common legal/factual dilemma emerges when the intervention forces claim that they are acting at the request of a competent 
Similarly, neither the Zero Treaty and R2P Treaty proposals transgress element (c2): the military action would be based on the state's prior exercise of its "political independence" in joining the treaty, overriding any contrary policy or objection expressed later by a subsequent government of the day. The crucial analytic move here is to preserve the enduring legal effect of the earlier expression of government consent, irrevocably issued when affiliating with the treaty, rather than honoring the privilege of a state to change its mind. 207

Element ( 1 1) would ordinarily not be relevant here, because the treaty enforcement mechanism would be only a temporary phenomenon, and would not challenge the "territorial integrity" of the state-the R2P or Zero organization would not undertake to fracture the state or detach any portions of it. ${ }^{208}$

Regarding element (c3), the "Purposes of the United Nations" are identified in Article 1 of the Charter, ${ }^{209}$ but they are expressed there in such

authority in the invaded state: the fundamental issue is whether the leader or spokesperson who provided that purported consent or invitation to the outsiders was truly authorized to do so under the domestic law of the invaded state. If the invaded stare is undergoing a trauma or transition, there may be considerable ambiguiry about which faction constitutes "the government" at any critical moment and is therefore legally competent to request or invite outside intervention. The leaders of a recentlyousted government or the leaders of a new incoming clique (or several) may be in contention, and disputants who are "recognized" by differing outside states may disagree about who can speak for the state at any particular moment. See, e.g., Henkin, Gross Violation, supra note 12, at 299-300 (regarding US claim about being invited into Panama in 1989); Doswald-Beck, Legal Validity, supra note 14, at 222-39 (evaluating interventions in Hungary, the Dominican Republic, Afghanistan, and Grenada, in which the existence or validity of an invitation is disputed); Wippman, Military Intervention, supra note 29, at 211-34; Hargrove, supra note 12, at 116-18; John Norton Moore, Grenada and the International Double Standard, 78 AM. J. INT'L L. 131, 145, 153-56 (1984) (stressing the effect of consent by the Governor-General of Grenada in assessing the legality of US action).

This Arricle sets aside this cluster of knotty problems, in order to address a related, but different question: May the lawful government of a state on Date D validly agree to a treaty under which it permanently binds the state to consent to future foreign military intervention, if it ever violates the treaty, even if a lawful, recognized subsequent government of that state on Date $D+1$ objects to the intervention and seeks to withdraw the earlier consent? Harrell, supra note 28, at 427-31 (asking whether a prior treaty can trump the wishes of the current government regarding use of military force against itself); Hathaway, Consent-Based, supra note 12, at 542-555; Wippman, Military Intervention, supra note 28, at 211-12; Rein Mullerson, Intervention by Invitation, in LAW AND FORCE IN THE New INTERnAtional ORder 127 (Lori F. Damrosch \& David J. Scheffer eds., 1991); Hathaway, International Delegation, supra note 67, at 127-33; Thomas Ehrlich, Cyprus, the "Warlike Isle": Origins and Elements of the Current Crisis, 18 StAN. L. Rev. 1021, 1071-75 (1966) (analyzing the legality of Turkey's invasion of Cyprus under the terms of Article 2(4) of the Charter).

207. In a similat vein, Steven Ratner has suggested that military intervention to promote human rights without Security Council authorization might be justified on the grounds that it does not constiture an action against the invaded state, but only against its government, and on behalf of its people, whose rights are being transgressed by the government and vindicated by the international community. See Ratner, supra note 80 , at 293 . Others have suggested that if a state fails its obligation ro protect its citizens from atrocities, it loses some of its erstwhile sovereign rights, including the right to reject foreign intervention. See Helal, Justifying War, supra note 26, at 599.

208. Kosovo would be an exception to this generality; there, one ultimate result of the intervention was the independence of Kosovo, formerly a province of Serbia. See Kosovo RePORT, supra note 84; Fonteyne, supra note 73 , at 253-58 (analyzing whether particular incursions should be understood to be contrary to the terms of Article 2(4)); Brownlie, supra note 17, at 265-68.

209. U.N. Charter, art. 1. 
sweeping and lofty rhetoric that little guidance is provided when some of those purposes may come into tension or conflict. Article 1 speaks fervently of preserving international "peace" (seeming to inveigh against military actions), but also of "security" (which the parties to a Zero Treaty could conclude was best promoted via enforced nuclear disarmament). ${ }^{210}$ It stresses "conformity with the principles of justice and international law," 211 but emphasizes the use of "peaceful means," 212 and it specifies that among the Charter's purposes is "promoting and encouraging respect for human rights and for fundamental freedoms for all." 213 The essential objectives of the Zero Treaty and the R2P Treaty are thus harmonious with the "Purposes of the United Nations," even if the mechanism for forcefully vindicating those objectives is not at all what was initially contemplated by the founders in 1945.214

Permanency. The hardest edge of the argument concerns the permanency of the parties' respective consents to the exercise of coercive military force. Without a durable grant of authority, the enforcement of the R2P Treaty or Zero Treaty (or at least the legal validity of the use of force) would falter; but that irrevocability may seem at odds with core notions of statehood. Which way do the principles of sovereignty push: should a state be regarded as retaining an inalienable right to change its mind on matters of this sort, or is it a valid exercise of sovereignty to bind itself indelibly in a way a successor government cannot unravel?215 Especially when the question concerns such core issues-human rights, national security, and the exercise of military force-the stakes are at their highest. ${ }^{216}$

210. Id. I 1

211. Id.

212. Id.

213. 1 d. $\uparrow 3$.

214. Hathaway, Consent-Based, supra note 12 , at 505 n.29 (discussing the debate whether humanitarian intervention is inconsistent with Article 2(4), since it does not usually challenge the territorial integrity or political independence of a state, bur does assert non-defensive force without authorization by the Security Council); Helal, Justifying War, supra nore 26, ar 604; Marc Weller, Introduction: International Law and the Problem of War, in The Oxford Handbook of the Use of Force in InternaTIONAL LAw 3, 18 (Marc Weller ed., 2015) (asserting that the argument "has not been accepted" that the final words of Article 2(4) narrow its meaning).

215. The possibility of a successor state (in contrast to a successor government) may raise some issues here, too-a newly emerging state may not be automatically bound by the treaties of its geographic predecessor state. See Vienna Convention on Succession of States in Respect of Treaties, Aug. 23, 1978, 1946 U.N.T.S. 3; Restatement, supra note 62, $\$$ 208, 210; Gerhard Hafner \& Gregor Novak, State Succession in Respect of Treaties, in The Oxford Guide to Treaties 396 (Duncan B. Hollis ed., 2012); Florentino Ruiz, The Succession of States in Universal Treaties on the Protection of Human Rights and Humanitarian Law, 7 INT'L J. HUM. RTs. 42 (2003); Helal, Justifying War, supra note 26, at 573 (asserting that recent practice leads to the conclusion that "human rights treaties are unaffected by state succession"); Hathaway, International Delegation, supra note 67, at 127-33; Beemelmans, supra note 188, at 84-108; Akbar Rasulov, Revisiting State Succession to Humanitarian Treaties: Is There a Case for Automaticity?, 14 EUR. J. INT'L L. 141 (2003).

216. Lieblich, supra note 15, at 365-67, 371-73, 382 (assessing whether consent may be withdrawn from a "forward-looking" treaty permitting subsequent military intervention); Wippman, Treaty-Based, stpra note 93, at 623-33 (proposing to require consent of the state at two moments in time: when the treaty is concluded, and when the intervention occurs); Debate, supra note 104, at 
Sometimes, international legal commitments are readily regarded as permanent, with no possibility of retraction or withdrawal. The VCLT specifies that a treaty containing no provision regarding its termination or denunciation is immune from those actions, unless it is established that the parties did intend to allow the possibility of escape, or that such rights are implied by the very nature of the treaty. ${ }^{217}$ The Charter and the VCLT itself are examples of treaties that contain no provision regarding duration, suspension or withdrawal. ${ }^{218}$

On the other hand, the well-established principle of rebus sic stantibus allows a party generally to terminate or suspend a treaty commitment when a "fundamental change of circumstances has occurred."219 Under the VCLT, this extrication can occur only if the alteration is unforeseen, has transformed an "essential basis" for the agreement, and has radically revised the obligations. ${ }^{220}$ This escape hatch is not exercised lightly, ${ }^{221}$ but it does represent another type of challenge to the permanency of even seemingly durable international agreements. ${ }^{222}$

In the realm of arms control, as noted supra, the general tradition has been to include a mechanism permitting a state to exit the treaty if it determines that its "supreme interests" have been jeopardized. ${ }^{223}$ In contrast, human rights treaties have been irregular regarding the incorporation of withdrawal or termination clauses, but some instruments do allow for temporary, formally-declared derogation or suspension. ${ }^{224}$

Some Semi-Precedential Cases. To assist in assessing the viability of the concept of contracting around the Security Council veto power, this section reviews some of the partially-apposite history of consent-based military intervention agreements. The survey is necessarily brief and impressionistic, rather than comprehensive, since (depending on one's judgments about the

111-13 (discussing whether withdrawal from a Zero Treaty should be permitted); Hathaway, ConsentBased, supra note 12, at 556-57; Harrell, supra note 28, at 429-30; Farer, Guarantor of Democracy, supra note 14, at 167-68; Tyagi, supra note 62; Naldi \& Magliveras, supra note 41; Perez, supra note 127 (arguing that some treaty obligations persist even after a state's withdrawal from the creaty).

217. VCLT, supra note 61, art. 56, para. 1; Restatement, supra note $62, \$ 332$.

218. Hathaway, Consent-Based, supra note 12 , at $561 \mathrm{n} .353$ (reporting wide, but not universal, agreement that withdrawal from the Charter is not permitted); Thomas \& Thomas, supra note 14 , at 156-58; Tyagi, supra note 62, at 101-02; Naldi \& Magliveras, supra note 41, at 121 .

219. VCLT, supra note 61 , art. 62; RestatemenT, supra note $62, \S 336$.

220. VCLT, supra note 61, art. 62; Restatement, supra note 62, $\$ 336$.

221. See The Gabčíkovo-Nagymaros Project (Hung. vs. Slovk.), Judgement, 1997 I.C.J. 7 (September 25) (rejecting Hungary's claim that an agreement about construction of locks on the Danube River could be terminated when economic and environmental factors made the project significantly less appealing, although not radically transformed).

222. See also VCLT, supra note 61, art. 61 (allowing withdrawal from a treary due to supervening impossibility of performance); Malgosia Fitzmaurice, Exceptional Circtmstances and Treaty Commitments, in The Oxford Guide to Treaties 605, 612-624 (Duncan B. Hollis ed., 2012) (discussing the doctrine of fundamental change of circumstances).

223. See supra text accompanying notes 124-26.

224. See stipra text accompanying notes 64-70 (observing that human rights treaties sometimes allow withdrawal and frequently permit limited, temporary derogation in time of emergency). 
relevant points of comparison) there could be many instances to scrutinize. But even this tour d'borizon demonstrates that something like the tactic envisioned here has proven legally and politically tolerable in a wide variety of circumstances. ${ }^{225}$

a. Pre-World War II Guarantee Treaties. The eighteenth, nineteenth and first half of the twentieth centuries abound with instances of countries $\mathrm{X}$ and $Y$ concluding agreements under which $X$ would "guarantee" the continued existence of certain conditions inside $Y$, and would hold a right to intervene militarily inside $Y$, if necessary, to ensure their perpetuation. The specified conditions so enshrined could include preservation of a particular monarchical dynasty in $Y$, other manifestations of internal stability inside $\mathrm{Y}$, the continued enjoyment of peace between $\mathrm{Y}$ and some other state $\mathrm{Z}$, or other desiderata. ${ }^{226}$

For example, in 1863, Great Britain, France, Russia, and Greece signed a treaty that guaranteed Greece a "monarchial, independent and constitutional State" under the sovereignty of Denmark; this accord was the basis for military intervention in Greece by the three guarantors in 1916-17.227 Similarly, the Treaty of Havana ${ }^{228}$ and the Treaty of Washington, ${ }^{229}$ both concluded in 1903, provided the United States unilateral rights to intervene in Cuba and Panama, respectively, to protect life, property, and individual liberty. ${ }^{230}$ Perhaps most conspicuously, the 1925 Locarno Treaties, a linchpin in the inter-war. European security structure, engaged Great Britain and Italy as guarantors of the reciprocal non-aggression pledges by Germany, France, and Belgium. ${ }^{231}$

These types of international agreements have faded since 1945, amid a general distaste for anything that so smacked of imperialism, and it is

225. See generally Hathaway, Consent-Based, supra note 12, at 511-19; Harrell, supra note 28, at 432-43; Lieblich, supra nore 15; Wippman, Treaty Based, supra note 93; Doswald-Beck, Legal Validity, supra note 14.

226. Wippman, Treaty-Based, supra note 93, at 613-15; Winfield, supra note 14, at 158-59 (citing guarancee trearies concluded between various countries in 1774, 1812, 1833, and 1878); Harrell, supra note 28, at 426-27; Brownlie, supra note 17, at 318-21.

227. Treaty between Great Britain, France, and Russia, on the one part, and Denmark, on the other part, Relative to the Accession of Prince William of Denmark to the Throne of Greece art. 3, July 13, 1863, reprinted in 12 Am. J. INT'L L. (Supplement) 75, 76 (1918); Brownlie, supra note 17, at 318; Harrell, supra note 28 , at 426.

228. Treaty Between the United States and Cuba Embodying the Provisions Defining the Future Relations of the United States with Cuba, U.S.-Cuba, art. III, May 22, 1903, 33 Stat. 2248.

229. Convention between the United States and the Republic of Panama for the Construction of a Ship Canal to Connect the Waters of the Atlantic and Pacific Oceans, U.S.-Pan., art. XXIII, Nov. 18, 1903 , reprinted in 3 Am. J. INT'L L. (Supplement) 130 (1909).

230. Harrell, supra note 28 , at 426 ; Winfield, supra note 14 , at 159 ; Thomas $\&$ Thomas, supra note 14 , at $23-32$.

231. Treaty of Mutual Guarantee Between Germany, Belgium, France, Great Britain, and Italy arts. 1, 2, 5, Oct. 16, 1925, 54 L.N.T.S. 305. 
doubtful whether such a broad, unencumbered right of intervention today would be consistent with Articles 2(4) and 2(7) of the Charter. ${ }^{232}$

b. Acheson-Lillienthal and Baruch Nuclear Plans. In the immediate postWorld War II period, the United States and the Soviet Union sponsored competing proposals for harnessing the awesome power of atomic weaponry. These programs involved some frangible mixture of international control over the arsenals; a corresponding mechanism for timely, certain detection of any cheating; and a stringent enforcement system of swift, condign punishment for violations. ${ }^{233}$ The first comprehensive US iteration of an arms control program, drafted by Dean Acheson and David Lilienthal in 1946, proposed an ambitious global Atomic Development Authority, which would be empowered with exclusive jurisdiction over all "intrinsically dangerous operations in the nuclear field." 234

Bernard Baruch adapted that scheme for presentation to the United Nations on June 14, 1946, and grafted onto it a muscular enforcement mechanism. ${ }^{235}$ In doing so, he highlighted a critical specification: the P5 veto power must not apply to any Security Council resolution that would impose sanctions or authorize military actions against a state that violated this most critical security arrangement. The choice of "World Peace or World Destruction," Baruch said, requires not only outlawing possession of atomic weaponry, but also a system of unavoidable enforcement powers:

It might as well be admitted, here and now, that the subject goes straight to the veto power contained in the Charter of the United Nations so far as it relates to the field of atomic energy. The Charter permits penalization only by concurrence of each of the five great powers - the Union of Soviet Socialist Republics, the United Kingdom, China, France, and the United States.

I want to make very plain that I am concerned here with the veto power only as it affects this particular problem. There must be no

232. Harrell, supra note 28, at 426; Wippman, Treaty-Based, supra note 93, at 614-15; Hachaway, Consent-Based, supra note 12 , at 558 n.333; Brownlie, supra note 17, at 320-21.

233. See Myrdal, supra note 98, at 77-84, 297-99, 304-05; Alessandro Corradini, General and Complete Disarmament, in 2 Encyclopedia of Arms Control and Disarmament 1041 (Richard Dean Burns ed., 1993); Randy Rydell, Nuclear Disarmament and General and Complete Disarmament, in THE Challenge of Abolishing Nuclear Weapons, supra note 104, at 227; International Arms ConTrol: Issues AND Agreements 68 (John H. Barton \& Lawrence D. Weiler eds., 1976).

234. David E. Lilienthal et. al, Report on the International Control of Atomic EnERGY $\$ 3$ (1946), http://www.learnworld.com/ZNW/LWText.Acheson-Lilienthal.html\#nuclear (last visited February 13, 2016) [hteps://perma.cc/4AEK-4YU3]; Randy Rydell, Looking Back: Going for Banuch: The Nuclear Plan that Refused to Go Away, Arms Control Ass'n (June 1, 2006), http://www .armscontrol.org/act/2006_06/LookingbackBaruch\#note11 [https://perma.cc/M9DC-ZAFQ]; The Ache son-Lilienthal $\mathcal{E}$ Baruch Plans, 1946, U.S. Dep't of State, Office of THE Historian, hetps://history.state.gov/milestones/1945-1952/baruch-plans (last visited Mar. 5, 2016) [https://perma.cc/Q8AZZNN2] [hereinafter U.S. Dep't of State, Plans].

235. See Rydell, supra note 234; U.S. Dep'T of STate, Plans, supra note 234. 
veto to protect those who violate their solemn agreements not to develop or use atomic energy for destructive purposes.

The bomb does not wait upon debate. To delay may be to die. The time between violation and preventive action or punishment would be all too short for extended discussion as to the course to be followed. ${ }^{236}$

The Acheson-Lillienthal and Baruch Plans were never effectuated-they were never even reduced to specific proposed treaty text-but were lost in the vicissitudes of cold war politics. Still, the concept of circumnavigating the P5 veto power in order to institute the abolition of nuclear weapons was planted less than one year after the destruction of Hiroshima and Nagasaki and the birthing of the United Nations. ${ }^{237}$

c. Cyprus. A prominent Charter-era illustration of the earlier practice of "guarantee treaties" was crafted in 1960 to deal with the uneasy circumstances of Cyprus, which became independent without full reconciliation between its rivalrous Greek and Turkish communities. A new constitution was fashioned to protect and permanently balance the equities of both ethnicities, and simultaneously a treaty between the newly independent state and three guarantors (the United Kingdom, Greece, and Turkey) preserved for each "the right to take action with the sole aim of re-establishing the state of affairs created by the present Treaty." 238

The government of Cyprus subsequently argued that the guarantee treaty was invalid because it was the product of illegitimate state coercion, and that the intervention powers of the guarantors were incompatible with the sovereignty principles of Article 2 of the Charter, but the Security Council was unresponsive. In 1974, a Greek-sponsored coup disrupted the status quo, and Turkey responded with an invasion, occupying the northern third of the island. In defense of its intervention, Turkey adamantly cited the treaty and its own role in preserving the enshrined rights of the minority population. ${ }^{239}$

The tenor of subsequent debates in the Security Council generally condemned both Greek and Turkish interference in Cypriot affairs, but did not fundamentally challenge the integrity or concept of the guarantee treaty or

236. The Baruch Plan, Atomic ARChive, http:/www.atomicarchive.com/Docs/Deterrence/BaruchPlan.shtml (last visited Feb. 13, 2016) [https:/perma.cc/69JY-AMCN].

237. Leneice N. Wu, The Baruch Plan 1946-1948, in 2 ENCYClopedia OF ARMS Control AND Disarmament 771 (Richard Dean Burns ed., 1993).

238. Treaty of Guarantee, Cyprus-Greece-Turk.-U.K., art. IV, Aug. 16, 1960, 382 U.N.T.S. 3; see Vincent L. Morelli, Cong. Research Serv., Cyprus: Reunification Proving Elusive (2015); Ehrlich, supra note 206; Marios L. Evriviades, The Legal Dimension of the Cyprus Conflict, 10 Tex. INT'L L.J. 227 (1975).

239. Wippman, Treaty-Based, supra note 93, at 633, 635-37; Doswald-Beck, Legal Validity, supra note 14, at 246-50; Morelli, supra note 238; Ehrlich, supra note 206; Evriviades, supra note 238; Roth, Illegality, supra note 90, at 339; David Wippman, International Law and Ethnic Conflict on Cypris, 31 TEX. INT'L L.J. 141 (1996) [hereinafter Wippman, Ethnic Conflict]. 
the reserved right to intervene. ${ }^{240}$ Forty years later, Turkish forces remain in place in northern Cyprus, and persistent efforts to reestablish a unified state have all been frustrated. ${ }^{241}$

d. Panama. In 1977, the United States and Panama entered into a series of treaties governing their respective future rights regarding the Panama Canal. ${ }^{242}$ The United States pledged not to intervene in Panama's internal affairs, and Panama granted the United States the right and primary responsibility to "protect and defend the Canal" and to act unilaterally "to meet the danger resulting from an armed attack or other actions which threaten the security" of the waterway. ${ }^{243}$

In 1989, the United States deployed 24,000 troops to Panama, engaged and defeated Panamanian forces, and deposed and seized Manuel Noriega, the de facto head of state, conveying him to the United States for trial on drug trafficking charges. The United States offered numerous candidate justifications for its intervention, including citing the treaties as an irrevocable pre-commitment by Panama to allow unilateral US military action where deemed necessary to safeguard operations of the canal. ${ }^{244}$

Commentators mostly rejected the proffered US legal rationales, both on factual grounds (e.g., arguing that the actual threat to the canal was minimal) and on legal grounds (e.g., maintaining that construing the treaties to authorize this sort of military action against the government of Panama would be inconsistent with the Charter and non-derogable norms. ${ }^{245}$ Louis Henkin, for example, emphasized that:

No government, in Panama or anywhere else, would conclude a treaty that would authorize what the United States did in Panama. Even if Panama and the United States had concluded such a treaty, it would be void; such a treaty would violate the UN Charter, which by its terms is to prevail over any inconsistent

240. Doswald-Beck, Legal Validity, supra note 14, at 248-50; Evriviades, supra note 238; S.C. Res. 541 (Nov. 18, 1983) (deploring the purported secession of Northern Cyprus and calling upon states nor to recognize it); Wippman, Ethnic Conflict, supra note 239.

241. Morelli, supra note 238.

242. Panama Canal Treaty, U.S.Pan., Sept. 7, 1977, 33 U.S.T. 39; Panama Canal Treaty (Permanent Neutrality and Operation), U.S.-Pan., Sept. 7, 1977, 33 U.S.T. 1, 1161 U.N.T.S. 177; Panama Canal Treaty (Implementation of Arcicle III), U.S.-Pan., Sept. 7, 1977, 33 U.S.T. 141.

243. Panama Canal Treaty, supra note 242, arts. I(2) \& IV $(1,2)$; Panama Canal Treaty (Implementation of Article III), supra nore 242 , art. II.

244. Abraham D. Sofaer, The Legality of the United States Action in Panama, 29 Colum. J. TRAns. NAT'L L. 281 (1991); Henkin, Gross Violation, supra note 12; Wippman, Treaty-Based, supra note 93, at 680-84.

245. Henkin, Gross Violation, supra note 12; Wippman, Treaty-Based, supra note 93, at 680-84; Ved P. Nanda, The Validity of United States Intervention in Panama Under International Law, 84 AM. J. INT'L L., 494 (1990); Byers \& Chesterman, supra note 38, at 274-79; Tom J. Farer, Panama: Beyond the Charter Paradigm, 84 AM. J. INT'L L. 503 (1990). But see Anthony D'Amato, The Invasion of Panama Was a Lawful Response to Tyranny, 84 AM. J. INT'L L. 516 (1990) (arguing in favor of the legality of the US intervention). 
treaties. It would violate the principles of Article 2(4) of the Charter which are jus cogens. ${ }^{246}$

In partial contrast, David Wippman has suggested that Panama could validly consent to this type of guarantee treaty or forward-looking consensual intervention treaty; he asserted that the more difficult question is whether Panama should be understood to have retained an indelible right to rescind that initial consent. He judges that "under the circumstances, it seems reasonable to conclude that Panama does not have the right to revoke the Canal Treaties because the grant of coercive authority at issue is sufficiently limited in scope and duration that it does not constitute a serious infringement on Panamanian independence." 247

e. Warsaw Pact and the Brezhnev Doctrine. A particularly egregious illustration of a "consent to be invaded" treaty was provided by the Warsaw Pact $^{248}$ and associated instruments, especially when amplified by the socalled Brezhnev Doctrine. ${ }^{249}$ Under this cluster of undertakings, the customary centrality of state sovereignty was abruptly limited-once a country had entered the communist constellation, any backsliding would be deemed "counter-revolutionary" and intolerable. The Soviet Union, as the world's leading socialist state, had the responsibility to intervene, by military means if necessary, to prevent such regression. Other members of the Warsaw Pact would assist, in fraternal solidarity, to defeat or oust their neighbor's government of the day that had deviated from its commitment to the historical dialectic. ${ }^{250}$

246. Henkin, Gross Violation, supra note 12 , at 309

247. Wippman, Treaty-Based, supra note 93 , at 683 .

248. Treaty of Friendship, Co-operation and Mutual Assistance, Alb.-Bulg.-Hung.-Ger. Dem. Rep.-Pol.-Rom.-Union of Soviet Socialist Republics-Czech, May 14, 1955, 219 U.N.T.S. 24. Nothing in this agreement indicates an overt consent to future interventions. The text speaks to the parties' commitment to the Charter (art. 1); their resolve to assist each other in collective self-defense (art. 4); their establishment of a military Unified Command (art. 5); and their rejection of any coalitions or alliances incompatible with the present text (art. 7). Associated instruments are slightly more explicit in contemplating future military activities, such as the Czechoslovakia and U.S.S.R. Treaty of Friendship, Co-operation and Mutual Assistance, signed May 6, 1970, under which the parties resolved "to continue along the path of socialist and communist construction," "take the necessary measure for the defence of the socialist achievements of the people" (art. 5), and to "make every effort to defend international peace and the security of peoples against the intrigues of the aggressive forces of imperialism and reaction" (art. 7). Treaty of Friendship, Co-operation and Mutual Assistance, Czech-Union of Soviet Socialist Republics, arts. 5, 7, May 6, 1970, 735 U.N.T.S. 220; see James P. Terry, Moscow's Corruption of the Law of Armed Conflict: Important Lessons for the 21st Century, 53 Naval L. Rev. 73, 88-100, 118-34 (2006).

249. Franck, supra note 27, at 832-34 (summarizing Brezhnev Doctrine, and comparing it to US policies toward its allies); Henkin, Reports of the Death, supra note 36, at 546 (comparing the Warsaw Pact to the Charter of the Organization of American States and concluding that nothing in the UN Charter "remotely affords the Brezhnev Doctrine a scintilla of legitimacy"); Moore, supra note 206, at 165-66; Francis A. Boyle, International Lawlessness in the Caribbean Basin, 21-22 Crime \& Soc. JUST. 37, 47-48 (1984); Terry, supra note 248, at 88-100, 118-34, 149-55; MurPHy, Humanitarian INTERVENTION, supra note 15 , at 86-92.

250. See Leonid Brezhnev, General Secretary of the Central Committee of the Communist Party of the Soviet Union, Brezhnev Speech to the Fifth PZPR Congress (Nov. 12, 1968), in ForeIGN Broad- 
This obeisance to the global march of communism is not overtly expressed in the treaty texts, and it is impossible to square with the Charter's enshrining of state sovereignty and equality. Still, it seemed to provide the jurisprudential hook for Soviet incursions into Hungary in 1956, Czechoslovakia in 1968, Afghanistan in 1979, Poland in 1981, and elsewhere. Those states were deemed by Moscow to have irrevocably consented in advance to corrective measures, should they ever too conspicuously depart from the path of ideological rectitude. ${ }^{251}$

f. Cuba and Grenada. Two Western Hemisphere treaties provide another basis for assessing the viability of a durable prior consent to an outside use of military force: the 1948 Charter of the Organization of American States $(\mathrm{OAS})^{252}$ and the 1981 Treaty Establishing the Organization of Eastern Caribbean States (OECS). ${ }^{253}$ The United States invoked the OAS Charter during the 1962 Cuban Missile Crisis as a justification for enforcing a "quarantine" of Cuba, to interdict the introduction of additional Soviet nuclear weapons there. ${ }^{254}$ Quincy W right observed at the time that a definitive OAS resolution in support of the blockade "might justify action

Cast Information Service, Special Memorandum, Public Warning Indicators of the Soviet Decision to Invade Czechoslovakia: A Retrospective Review 64 (Nov. 4, 1980), http://www .foia.cia.gov/sites/default/files/document_conversions/1700321/1980-11-04.pdf [https://perma.cc/4PS4ZZRQ] ("However, it is known, comrades, that there also are common laws governing socialist construction, a deviarion from which might lead to a deviation from socialism as such. And when the internal and external forces hostile to socialism seek to revert the development of any socialist country toward the restoration of the capitalist order, when a threat to the cause of socialism in that country, a threat to the security of the socialist community as a whole, emerges, this is no longer only a problem of the people of that country but also a common problem, concern for all socialist states.").

251. See Sovereignty and the International Duties of Socialist Countries, PRAvDA, Sept. 25, 1968, reprinted in 7 I.L.M. 1323 (1968) ("In fulfilling their international duty to the fraternal people of Czechoslovakia and defending their own socialist achievements, the Soviet Union and the other socialist states had to act, and did act, decisively against the anti-socialist forces in Czechoslovakia."); Permanent Representative of the Union of Soviet Socialist Republics, Soviet Opposition to UN Security Council Consideration of Situation in Czechoslovakia: Letter Dated 21 August 1968 from the Permanent Representative of the Union of Sovier Socialist Republics Addressed to the President of the Security Council, U.N. Doc. S/8759 (Aug. 21, 1968) ("[T]he Socialist states cannot and will not allow the kind of situation in which the vital interest of socialism are infringed upon [or] encroachments are made upon che inviolability of the frontiers of the socialist commonwealth."); Memorandum from Roberts B. Owen, Legal Adviser of the Dep't of State, to Warren Christopher, Acting Sec'y of State (Dec. 29, 1979), excerpted in Marian L. Nash, Contemporary Practice of the United States Relating to International Law, 74 AM. J. INT'L L. 418,418 (1980) (critiquing the Soviet justification for the 1979 invasion of Afghanistan; asserting that if there were a U.S.S.R.-Afghanistan treaty that purported to justify the intervention, it would be void as a violation of jus cogens); Doswald-Beck, Legal Validity, supra note 14, at 222-26, 230-34 (scrutinizing the lack of valid legal basis for Soviet incursion into Hungary in 1956 and Afghanistan in 1979); Mullerson, supra note 206, at 128; Wippman, Treaty-Based, supra note 93, at 620-21.

252. Charter of the Organization of American States art. 29, Apr. 30, 1948, 2 U.S.T. 2394, 119 U.N.T.S. 3, (pledging coordinated measures in response to an armed attack" or "any other fact or situation that might endanger the peace of America."); see also Inter-American Treaty of Reciprocal Assistance arts. 2, 3, 6, Sept. 2, 1947, 62 Stat. 1681, 21 U.N.T.S. 77 (committing to joint action on similar terms).

253. Treaty Establishing the Organization of Eastern Caribbean States, June 18, 1981, 1338 U.N.T.S. 97, 20 I.L.M. 1166 [hereinafter OECS Treaty].

254. President John F. Kennedy, Address, The Soviet Threat to the Americas (Oct. 22, 1962), in Dep't of St. Bull., Nov. 12, 1962, at 715 . 
against Cuba on the ground that as a member of O.A.S. Cuba had constructively consented and so was legally bound by it." But, he added, such a resolution would provide no basis for forceful action against the Soviet Union, whose ships were the sole target of the quarantine, because the U.S.S.R. was not a member of the OAS and had not accepted any obligations pursuant to it. ${ }^{255}$

Even more pointedly, the 1983 US-led invasion of Grenada rested in large measure upon authorization from the OECS. ${ }^{256}$ The organization's constitutive act is mainly concerned with trade, economics, and cultural advancement, but there are also some general provisions regarding defense and security. In particular, the OECS Governing Authority is empowered to "make such recommendations and give such directives as it deems necessary for the achievement of the purposes" of the organization. ${ }^{257}$ On October 21,1983 , distressed by civil disruptions in Grenada and the leftward lurch of the government there, the OECS voted to suspend diplomatic relations with Grenada and to impose sanctions; three days later it authorized military intervention. In view of the members' paltry military capabilities, they invited the United States and other Caribbean powers to conduct the military operation, which was swiftly successful. ${ }^{258}$

Subsequent debates in the United Nations General Assembly were generally critical of the operation, on the grounds that it violated the universal principles against foreign intervention in the internal affairs of a state. Few participants parsed the language of the OECS Charter to determine whether it could be fairly read as constituting Grenada's prior consent to such an operation, or to ponder whether such an irrevocable commitment would be valid. ${ }^{259}$

g. West Africa. The most important contemporaneous illustrations of a durable regional treaty-based consent to an outside use of force come from the Economic Community of West African States (ECOWAS) and the Afri-

255. Wright, Cuban Quarantine, supra note 179, at 558; see also Franck, Who Killed, supra note 17, at 833-34 (likening the US approach to Cuba, and the asserted right to prevent the establishment of another Communist regime in the Western Hemisphere, to the practices of the Soviet Union under the Brezhnev Doctrine, and concluding that both rationales are inconsistent with the Charter); Harrell, supra note 28 , at $433-36$.

256. Kenneth W. Dam, Deputy Sec'y of State, Statement Prepared for Presentation before the House Committee on Foreign AfFairs (Nov. 2, 1983), reprinted in Marian Nash Leich, Contemporary Practice of the United States Relating to International Law, 78 AM. J. INT'L L. 200, 202-03 (1984); Harrell, supra note 28, at 436-38; Doswald-Beck, Legal Validity, supra note 14, at 234-39; Christopher C. Joyner, The United States Action in Grenada: Reflections on the Lawfulness of Invasion, 78 AM. J. INT'L. L. 131, 135-37 (1984); Ronald M. Riggs, The Grenada Intervention: A Legal Analysis, 109 Mit. L. REv. 1 (1985); John Quigley, The United States Invasion of Grenada: Stranger than Fiction, 18 U. MIAMI INTER-AM. L. Rev. 271 (1987); Murphy, Humanitarian INTERvention, supra note 15, at 108-11.

257. OECS Treaty, supra note 253 , arts. $6.6,8.3$.

258. Harrell, supra note 28, at 437; Doswald-Beck, Legal Validity, supra note 14, at 235-36; Joyner, supra note 256; Moore, supra note 206.

259. Doswald-Beck, Legal Validity, supra note 14, at 236-39; Harrell, supra note 28, at 437-38; Joyner, supra note 256; Moore, supra note 206, at 157-59; Boyle, supra note 249, at 42-45; Byers \& Chesterman, supra note 38 , at 271-74. 
can Union (AU). The decades of tumult in West Africa have provided the stage for all manner of military activities: some that were undertaken with the prior authorization from the Security Council, as contemplated by the Charter; some that were initiated autonomously, but welcomed or ratified by the Security Council after the fact; some that were based on the consent of the invaded government (or at least of a putative contending faction); and some that have proceeded entirely outside the ambit of Chapter VII. ${ }^{260}$

ECOWAS was founded in 1975 as a relatively modest sub-regional enterprise, focused largely on facilitating and enhancing its members' economic relations, but it also gradually came to assume a more prominent military role. ${ }^{261}$ The 1999 Lome Protocol solidified this transformation, permanently establishing the ECOWAS Cease-Fire Monitoring Group (ECOMOG) as a standing military force poised for immediate deployment. ${ }^{262}$ Under Article 25 of ECOWAS, this mechanism is to be available even in cases of "internal conflict that threatens to trigger a humanitarian disaster or that poses a serious threat to peace and security," or "in the event of serious and massive violation of human rights and the rule of law." 263 The authority to initiate ECOMOG operations is conferred upon ECOWAS, the United Nations, and the African Union, even in the absence of a contemporaneous consent or request from the targeted member state. ${ }^{264}$

The larger African Union-responding to a long series of appalling humanitarian catastrophes that did not incite sufficient response from the United Nations or other authorities-has likewise empowered forceful, non-consensual intervention inside the territory of its members, via the 2002 Durban Protocol Relating to the Establishment of the Peace and Security Council of the African Union. ${ }^{265}$ This accord is to be guided by the principle of "non-interference by any Member State in the internal affairs of another," 266 but it also explicitly endorses "the right of the Union to intervene in a Member State pursuant to a decision of the Assembly in respect of

260. Lieblich, supra note 15 , at 367-71 (citing examples of bilateral forward-looking intervention agreements between West African states); Harrell, supra note 28, at 438-40, 442; Hathaway, ConsentBased, supra note 12, at 515-18; Wippman, Military Intervention, supra note 28, at 224-30; Levitr, supra note 90, at 795-819; Anthony Chukwuka Ofadile, The Legality of ECOWAS Intervention in Liberia, 32 Colum. J. Transnat'l L. 381 (1995); David Wippman, Enforcing the Peace: ECOWAS and the Liberian Civil War, in Enforcing Restraint: Collective Inter vention in Internal Crises 157 (Lori Fisler Damrosch ed., 1993).

261. Harrell, supra note 28, at 438; Levitt, supra note 90, at 795-811; Allain, stpra note 19, at 260-62; Ofodile, supra note 260.

262. Economic Community of West African States [ECOWAS], Protocol Relating to the Mechanism for Conflict Prevention, Management, Resolution, Peace-Keeping and Security, arts. 17, 21, ECOW AS Doc. A/P10/ 12/99 (Dec. 10, 1999), http://ecowas.us/files/mechanism_of_conflict_prevention_protocol.pdf [https:// perma.cc/PKS3-XSVA].

263. Id. at art. 25 .

264. See id. at art. 26.; Levitt, supra note 90, at 807-811; Allain, stpra note 19, at 259-62.

265. See African Union [AU], Protocol Relating to the Establishment of the Peace and Security Conncil of the African Union (July 9, 2002), http://www.peaceau.org/uploads/psc-protocol-en.pdf [https://perma.ccl XS4M-HN7B] [hereinafter Peace and Security Conncil]; Levitt, supra note 90, at 824-830.

266. Id. at arr. $4 \mathrm{f}$. 
grave circumstances, namely war crimes, genocide and crimes against humanity." 267 Not only may the organization override a member's opposition to being so targeted, but such a rogue state is even excluded from participating in the decision-making process. ${ }^{268}$ Both the Lome Protocol and the Durban Protocol have been interpreted as asserting a right for the organizations to proceed with military activity against a recalcitrant member state even without Security Council blessing. ${ }^{269}$

These are not merely paper authorities, though they have not yet been overtly and officially activated in conflict. Nor have they received much outside scrutiny or triggered either widespread criticism or emulation. ${ }^{270}$ As David Wippman has noted, the sui generis nature of the West African security situation may carve out a special niche for this type of regional, non-Charter-based intervention authority:

ECOWAS and AU claims of a right to intervene in grave circumstances have garnered surprisingly little attention, in part because most states would welcome any means to curtail Africa's many festering conflicts and because the United Nations has repeatedly proven unwilling to tackle such conflicts itself. ECOWAS intervention in Liberia, and later Sierra Leone, followed unsuccessful efforts to persuade the Security Council to take meaningful action. So long as future actions by ECOWAS and the AU fit that pattern, they are unlikely to attract much criticism, even if they do not fit with the Charter scheme for the use of force. In any event, given political and resource constraints, neither ECOWAS nor the AU is likely to employ its claimed mandate to intervene very often. And the ECOWAS and AU models are unlikely to be replicated, or accepted, elsewhere, so

267. Id. at arts. 4j, 7e; see Allain, supra note 19, at 282 (observing that the scope of authority for the African Union to intervene in the territories of member states to protect against human rights violations is "far wider than the powers of the United Nations Security Council").

268. See Peace and Security Council, supra note 265, at art. 8.9 (stipulating that the Peace and Security Council shall hold closed meetings; any member that is a party to a conflict or other siruation that is under consideration "shall not participate either in the discussion or in the decision making process."; it may present its case to the Council, but must thereafter withdraw from the proceedings).

269. See Lieblich, supra note 15, at 369-71 (construing the Lome Protocol and the AU Protocol as giving a "cold shoulder" to the Security Council's monopoly on the authorization for intervention); Allain, supra note 19, at 261,264-65 (contending that "the African Union has appropriated for itself the role which the UN Security Council is meant to play"); Levitt, supra note 90; Kioko, supra note 60; Kwame Akonor, Assessing the African Union's Right of Humanitarian Intervention, 29 CRIM. JUST. ETHICs 157 (2010).

270. See Lieblich, supra note 15 , at 368-69 n.158 (noting that the South African Development Community has partially emulated the ECOMOG structure, but without the clarity of the authorization for intervention against the wishes of a targeted state); Levitt, supra note 90, at 818-823; Allain, supra note 19 , at 276. 
their impact on the Charter as a whole will likely remain modest. $^{271}$

\section{PART V: CONCLUSION}

Bottom Line. This could work. The parties that negotiate and join an R2P Treaty (in pursuit of enhanced global protection against human rights atrocities) or a Zero Treaty (to achieve world-wide nuclear disarmament) could validly provide informed consent to establish and reciprocally submit themselves to this type of enhanced enforcement mechanism. They could mutually authorize the use of military muscle, in the most extreme cases, by a new treaty-created mechanism, even without the contemporaneous endorsement by the UN Security Council or a self-defense justification. Sovereign consent does provide a sufficient warrant for escaping the otherwise compulsory grasp of the P5 veto power, which has too often precluded, diluted, or delayed effective global responses to the most pressing security and humanitarian challenges.

But it remains a close case. ${ }^{272}$ The hard version of the doctrine of R2P is still distinctly a minority view. Furthermore, the proposed circumvention of the Security Council's reign is especially problematic here because this new contemplated scheme simultaneously: (a) concerns the lawful use of military force, which has always been the most extreme form of international interaction and which has, since 1945 , been entrusted almost solely to the Security Council; (b) implicates national decisions about armaments and about the treatment of a state's own nationals, trampling upon two of the most sensitive matters in which outside intervention is historically most unwelcome; and (c) is necessarily permanent and irrevocable, requiring each sovereign to eschew the right ever to change its mind.

Only the most pressing imperatives - such as the need to safeguard the planet against the specter of nuclear Armageddon or the compelling obligation to end impunity for war crimes, genocide, and crimes against human-

271. Wippman, Nine Lives, supra note 17 , at 405 ; see also Allain, supra note 19 , at 238 (calling the African Union's treaty-based intervention power "the first true blow to the constitutional framework of the international system established in 1945 predicated on the ultimate control of the use of force by the United Nations Security Council"); Hathaway, Consent-Based, supra note 12, at 556 (calling the ECOWAS and AU treaties "a promising framework"); Hathaway, Consent-Based, supra note 12, at 563 n. 363 (expressing skepticism about the "dangerously broad" wording of the ECOWAS authorization for interventions); Int'l Peace Inst., Office of the Special Adviser on the Prevention of Genocide, United Nations Interafrica Group, The Responsibility to Protect (RtoP) and Genocide Prevention in Africa (2009), http://reliefweb.int/sites/reliefweb.int/files/resources/B088CEE65 4E6058B492575E8002513E9-Full_Report.pdf [https://perma.cc/CLZ8-2K]X] (discussing the special circumstances of the R2P doctrine in Africa).

272. See Doswald-Beck, Legal Validity, supra note 14, at $244-45$ (surveying eminent authorities on boch sides of the question about the legitimacy of foreign intervention pursuant to consent-based guarantee treaties); Wippman, Treaty-Based, supra note 93, at 610 (outlining two different theorecical approaches to the problem); Hathaway, Consent-Based, supra note 12, at 558-59; Lieblich, supra note 15, at 382 . 
ity-could motivate states to so fundamentally challenge the post-World War II structures of international relations. But as Richard Butler warns, the existing Security Council structure may have passed its use-by date, 273 and these overarching incentives may create a "constitutional moment" for revisiting the underpinnings of the Charter. "Outsourcing" a measure of the Security Council's responsibilities to new organizations may be the order of the day.

The remit of the Security Council, as the ICJ reminds us, ${ }^{274}$ is to wield "primary" (but not "exclusive") responsibility for the maintenance of international peace and security. ${ }^{275}$ The Security Council exists to facilitate the pursuit of the Purposes and Principles of the United Nations ${ }^{276}$ - it is not an end in itself - and if the member states now find it propitious to augment the existing veto-encrusted global security structures by creating new specialized treaty-based institutions, they should be free to do so. The supervening power of Article 103 (ensconcing the Charter as superior to any other prior or subsequent international agreement) and the status of Article $2(4)$ as jus cogens (from which no deviation is permissible) do not obliterate the power of state consent.

There is admittedly something of a conundrum here: can a sovereign state validly consent to a permanent limitation upon its future power? Is it a sacrifice, or an exercise, of sovereignty for today's government to irrevocably bind all its successors to receive foreign military intervention, if the state ever transgresses these fundamental norms? ${ }^{277}$ This Article concludes that at least in these two most pressing areas of international life, in which the legacy institutions have proven inadequate, a non-rescindable consent should be legally and politically acceptable.

Reinforcements. There are, fortunately, some mechanisms that could usefully reinforce the contemplated structure. First, the UN General Assembly and Security Council could endorse the new R2P and Zero treaty organizations and expressly support the states' conferral of military intervention power upon them. A Chapter VII resolution (or an amendment to the Charter) could confirm the parties' collective ability to supplement the existing enforcement routines, easing any supposed conflict between the new treaties and Article 103.278 If we posit sufficient consensus-especially among the planet's leading states-to create these new treaties and their muscular enforcement mechanisms, then it should not be too difficult to assume that at

273. Burler, supra note 32 , at 38 .

274. Military and Paramilitary Activities in and against Nicaragua (Nicar. vs. U.S.), Judgment, 1984 I.C.J. Rep. 392, ๆ 90-98 (Nov. 26).

275. U.N. Charter, art. 24, ๆl 1.

276. Id. If 2; see Reisman, Coercion and Self-Determination: Construing Charter Article 2(4), supra nore 11 , at $644-45$.

277. Hathaway, Consent-Based, supra note 12, at 560-63; Wippman, Treaty-Based, supra note 93, at 610-11.

278. See supra text accompanying nores 167-168 (concerning Article 103). 
(nearly) the same time, there will also be sufficient consensus among the P5 to formally seal the sacrifice of some of their erstwhile veto power. There may be a jurisprudential puzzle about whether the Security Council could legitimately "delegate" 279 some of its Chapter VII power to these new extramural institutions. However, well short of any formal handover of authority, the Security Council could meaningfully ratify the states' collective choice to stand up the new organizations.

Second, the negotiating states could explicitly address the "withdrawal" problem and formally decide what, if any, changed circumstances, or other foreseen or unforeseen developments, should allow a party to rescind its consent to the Zero or $\mathrm{R} 2 \mathrm{P}$ treaties. ${ }^{280}$ Some types of international agreements are deliberately made quite durable, and rebus sic stantibus is hardly a favored doctrine, but attention to any possible future "exit strategy" could help further entrench the agreements. ${ }^{281}$ The parties could likewise address the contingency of a state's unilateral response to a treaty violation by another state, perhaps limiting even in that circumstance the customary ability to suspend or terminate counter-performance. ${ }^{282}$

Third, it is noteworthy that most of the precedential treaties surveyed above that confer a non-Security-Council-based consent to foreign intervention have been geographically regional in character. Africa-West Africa, in particular-has been the "poster child" for this concept, and localized arrangements for Eastern Europe, Cyprus, etc., as well as purely bilateral instruments, have been the favored modality. ${ }^{283}$ In contrast, the R2P and Zero treaties are intended to have universal coverage. Oona Hathaway and her colleagues have highlighted the advantages and disadvantages of a regional approach for human rights instruments: neighbors who know each other relatively well may find it easier (or harder) to set aside political differences and may be less (or more) prone to abuse their less powerful colleagues. ${ }^{284}$ In any event, some additional thought should be given to the

279. See United States v. Curtiss-Wright Exp. Corp, 299 U.S. 304 (1936) (articulating the proposition that one branch of the US government may not delegate too much of its constitutional power to another branch).

280. See supra text accompanying notes 124-126 (regarding supreme interests withdrawal clauses); supra text accompanying notes 64-70 (regarding denunciation and derogation from human rights treaties); supra text accompanying notes 220-223 (regarding the principle of rebus sic stantibus); see also Tyagi, supra note 62 , at 128-34 (discussing the difficulty of assessing any unexpressed intentions of negotiators regarding possible right to withdraw from a treaty).

281. See supra text accompanying note 220-223 (regarding the doctrine of changed circumstances); see also Wippman, Treaty-Based, supra note 93, at 646-648 (proposing to allow rescission of treaty obligations, but to demand consensus within all the state's relevant political communities about that rescission).

282. See supra notes $62-63$ (regarding remedies for responding to another party's breach of a multilateral treaty under Article 60 of the Vienna Convention on the Law of Treaties).

283. See supra text accompanying notes 203-205 (surveying prior treaties of guarantee).

284. Hathaway, Consent-Based, supra note 12, at 557-59; see also Harrell, stipra note 28, at 431-32, $443-46$. 
methods for applying "lessons learned" from regional successes onto a global stage.

Finally, it must be stressed that this is not a generalized, broad-gauged assault on the perquisites of the Security Council. What is at stake here are two specified areas of international practice. They are two large and critically important areas, but they leave intact the traditional role of the Security Council across the rest of its exceedingly vast palate. The R2P and Zero treaties address topics of unique importance; they do not portend a more generalized effort to poach more Chapter VII turf. ${ }^{285}$

As noted above, these two policy priorities are so important (and so difficult, and so unfulfilled by the current structures) that it is appropriate to stretch the legal and policy analysis as far as it can go. The pursuit of fundamental human rights and the avoidance of nuclear holocaust represent sui generis global challenges and could stimulate a unique global consensus to act. Each person-or, for this purpose, each state-really is our brother's keeper, and we are also appropriately concerned about what weapons of mass destruction that brother may still be hiding (for the Zero Treaty) and about how that brother may be mistreating his own family (for the R2P Treaty).

Better enforcement-through more conspicuous, reliable legal institutions-can exert a powerful deterrent role in these two areas. If the world were to establish a functional accountability mechanism, a rogue state (or the particular cadre of malefactors who were temporarily in charge there) would appreciate that the odds of succeeding with a contemplated violation of the Zero or R2P treaty were reduced. A credible deterrence system requires that the enforcers possess, and communicate, a capacity for efficacious countermeasures, and a resolute will to apply them. These messages can be dispatched more vigorously when they emanate from an organized, dedicated treaty coalition, rather than from any one state (which might be haphazard in its willingness to act) or from the inevitably politicized Secur-

285. If state consent is sufficient to overcome the erstwhile constraints of Article 2(4) and jus cogens in these two areas, it may be asked whether a state could similarly consent to other transgressions of fundamental norms. That is, could a state, by similar analysis, effectively consent to a treaty legitimizing, in some sense, slavery, piracy or genocide? See supra notes 203-205. The critical distinction lies in the fact that consent (or, really, lack of consent) is an essential component of the definition of an illegal use of military force-if the invaded state provides consent, then the intervention does not constitute the offense of aggression, and is not a violation of the Charter or jus cogens. In contrast, state consent is irrelevant to the definition of other jus cogens violations, and no state can render them consistent with the purposes of the Charter. See Int'1 L. Comm'n, Draft Articles, supra note 16, at 85, \6 (concluding that "in applying some peremptory norms the consent of a particular State may be relevant," so a state may not dispense with the obligation to comply with the rules against, say, genocide, but it could permit a foreign military presence on its territory for a lawful purpose); Reisman, Termination, supra note 168 , at 153 (stressing the importance of mutual agreement regarding interventions). Looked at another way, a hypothetical treaty that attempted to legitimize piracy, slavery or apartheid, and that relied for its enforcement upon the parties' prior consent to an invasion, could be seen as a "double" violation of jus cogens. The parties' consent could suffice to cure the second half-as it does in the human rights and nuclear disarmament scenarios discussed in this Article-but would not save the first violation, i.e., the attempted legitimization of piracy, slavery or apartheid. 
ity Council. If the party contemplating a material breach of the treaty recognizes that it could no longer hope to play the veto card in the United Nations, it may understand more fully the adverse consequences of its misdeeds, and be deterred from committing violations.

The sad fact is that the present veto-bound system of the Security Council simply does not work for either human rights or disarmament. It has not enabled the world community to proceed with sufficient clarity and zeal toward vindication of those critical purposes of the United Nations. Moreover, the present configuration of rights and responsibilities does not serve the interests of international law either. When there is such a profound gap between law on the books and law in practice, something is surely amiss. ${ }^{286}$

Points of Comparison. This Article is the first to juxtapose the analysis of human rights with the analysis of nuclear disarmament in this manner. What are the salient points for comparison and contrast?

First, the Zero Treaty would require participation by all of the P5, and by all other states that possess nuclear weapons, ${ }^{287}$ - and sooner or later (probably sooner), by absolutely all states, since any location on earth could be a conceivable hiding place for contraband nuclear arms and related activities. Membership in an R2P Treaty, in contrast, could grow more deliberately and organically, as most human rights treaties have done. ${ }^{288}$ This contrast should not be overstated-even the 1968 Nuclear Non-Proliferation Treaty, arguably the most important arms control instrument in history, attained its current near-universal coverage only incrementally, with behemoths France and China not joining until $1992 .{ }^{289}$ So there could be some similarly extended "ramp-up" period for a Zero Treaty, but sustained holdouts could not be safely tolerated.

More pointedly, the Zero Treaty could not be concluded without ironclad enforcement measures. The leading nuclear-weapons-possessing states would not be willing to let down their guards, if a serious violation could go unremediated due to a procedural impediment such as the P5 veto in the Security Council. In contrast, a viable R $2 \mathrm{P}$ Treaty could rationally be concluded and honored by many states, even if one or a few stayed away from it or violated it. That is, the value of state $\mathrm{X}$ complying with legal strictures against genocide, torture or ethnic cleansing is not diminished even if state

286. But see Henkin, Reports of the Death, supra note 36, at 544 (arguing that Article 2(4) "has indeed been a norm of behavior and has deterred violations").

287. In addition to the P5, India, Israel, North Korea and Pakistan possess nucleat weapons. Nuclear Weapons: Who Has What at a Glance, Arms Control Ass'n, hetp:/www.armscontrol.org/ factsheets/Nuclearweaponswhohaswhat (last visited Feb. 25, 2016) [https:/perma.cc/W6AV-ZL4Q].

288. For example, the ICCPR has had gradual accumulation of ratifications. Supra note $42 ;$ see Status of Ratification, The Office of the U.N. High Comm'r for Human Rights, http://indicators.ohchr.org/ (last visited Mar. 5, 2016) [https://perma.cc/U3BW-SS54] (chronology of states incrementally accepting human rights treaty obligations).

289. Treaty on the Non-Proljferation of Nuclear Weapons, U.N. Office for DisarmaMENT AFFAIRS, http:/disarmament.un.org/treaties/t/npt (last visited Mar. 5, 2016) [https://perma.cc/ VX38-RPYW].China ratified the NPT in March 1992, and France ratified in August 1992. Id. 
$Y$ breaches; Y's bad acts do not undermine X's security or vitiate the reasons for $\mathrm{X}$ to continue to honor its commitments. In this sense, there could be no "soft version" of a Zero Treaty, as there is with $\mathrm{R} 2 \mathrm{P}^{290}$ - if the route to efficacious enforcement has to run through the veto in the Security Council, then there simply will be no Zero Treaty.

Looked at another way, the traditional "tit for tat" strategy of responding to another state's violation of a treaty by undertaking a reciprocal violation may work (more or less) for a Zero Treaty, but not for an R2P Treaty. That is, when state $Y$ violates its nuclear arms control obligations, state X's self-help option (in the absence of a mandatory treaty enforcement mechanism) could be to establish, or re-establish, its own offsetting nuclear arsenal, even if that requires setting aside its own erstwhile treaty obligations. In contrast, for a human rights instrument, Y's violation or non-participation does not alter the importance, desirability, and feasibility of continued good behavior by $\mathrm{X}$ - a retaliatory violation will not likely drive $\mathrm{Y}$ back into compliance and will only further degrade respect for the human rights norm in question. Deterrence by threat of retaliation in kind thus plays a much smaller role in human rights than in disarmament. ${ }^{291}$

For this reason, the great powers (especially the United States, Russia, and China) should be much more willing to compel the "hard cases" - the potential "holdout" states, including their familiar "clients" and affiliates, such as Israel, Iran, and North Korea-to join the disarmament regime. Even the superpowers could not safely participate in a nuclear potlatch if potential rogue regimes remain outside the treaty structure. But they may not find it quite so indispensable to force North Korea or other outliers to submit promptly to an R2P Treaty - the rest of the world can still proceed without them. In this vein, it may be possible to imagine the instigation of a compulsory Zero Treaty if only the three leadership teams-in Washington, D.C., Moscow, and Beijing-coalesce around the idea. If sufficiently motivated by an appreciation that complete, universal nuclear disarmament truly served their own enlightened long-run self-interest, they could, and would, compel others to participate; in contrast, they may not have a similar fastidiousness for globalizing a human rights norm. ${ }^{292}$

In the same vein, we might also ask what would happen, under either treaty, if a powerful and particularly aggrieved state concluded that the new treaty implementation body had reached the wrong decision about another party's debatable violation and the appropriate enforcement measures that

290. See supra text accompanying notes 79-81 (regarding "soft version" of R2P).

291. See supra text accompanying notes 128-129 (regarding the continuing relevance of deterrence and the threat of reconstirution of nuclear arsenals under a Zero Treaty).

292. See Schell, supra note 117, at 97 (arguing that if only three key countries--the United States, Russia and China-became fully committed to nuclear disarmament, then the concept could be made to work); Debate, supra note 104, at 113-14 (citing former US Secretary of State George P. Shultz for the proposition that a few leaders of key nuclear armed states, stepping forward with conviction and determination, could solve many of the problems that block a Zero Treaty). 
should be undertaken to redress or counteract it. Even if unencumbered by the Security Council's veto power, the new institutions may simply make an erroneous judgment (or at least a judgment that strikes some participants as woefully incorrect on the substance or procedures). ${ }^{293}$ Of course, there would remain some scope for unilateral responses, both peaceful (e.g., undertaking offsetting adjustments in one's own military posture) and forceful (i.e., still illegal under the standard international law analysis sketched above). ${ }^{294}$ These types of self-help interventions would seem more plausible in the case of a Zero Treaty, where an unredressed violation could be a threat to a state's national security, than for an R2P Treaty.

There may also be some interesting synergy between the two areas of law analyzed in this Article. For example, to date, the question of undertaking national or coalition military operations without a Security Council blessing has advanced further in the human rights field than in arms control. That is, the hard version of R2P has not commanded widespread (or even majority) support, but at least it is now a part of the international dialogue. The cognate concept of enforcement of a disarmament treaty is still too speculative and futuristic to have received much scholarly or practitioner attention. On the other hand, the case in favor of vigorous, timely, and forceful (if necessary) enforcement of a Zero Treaty is, if anything, even more compelling than the case for muscular enforcement of an R2P Treaty. Accordingly, if the concept of working around the Security Council gains traction in the arms control context, perhaps it can bleed into the human rights sector, too, and the world will develop a greater appetite, or at least tolerance, for leaving the veto power behind, when necessary, to accomplish goals regarding either human rights or nuclear disarmament.

Finally, another intrinsic contrast is noteworthy. Regarding human rights, everyone agrees with the objectives of the treaties in question (i.e., no one actively supports the idea of conducting, promoting, or protecting war crimes or crimes against humanity, even if some people niggle with the specific definitions or particular applications, or chafe under the accompanying international oversight). But mobilizing the international community to effectuate those commitments by mounting a substantial military or law enforcement campaign is often difficult--people are routinely not eager to devote national blood and treasure to end impunity in far distant lands. For a Zero Treaty, precisely the opposite relationship exists between ends and means. That is, the desirability, feasibility, and sustainability of the complete abolition of nuclear weapons are matters of spirited debaremany challenge the wisdom of concluding or even approaching true dis-

293. See supra text accompanying notes 154-156 (regarding the question of whether a treaty implementation body would make decisions about authorizing military enforcement measures by simple majority vote of the parties or through some supermajority or qualified voting process).

294. See supra text accompanying notes 175-180 (addressing the limited bases upon which a state may lawfully resort to international armed force). 
armament. ${ }^{295}$ However, everyone agrees that if a Zero Treaty were in place, and if a serious violation of it were detected, then a vigorous enforcement campaign should be immediately and vigorously pursued.

Cautionary Notes. We should not bring a monocular focus to this complex set of issues. Instead, we need to consider all of the available perspectivessituations in which justice, international security, and peace demand intervention (even if one of the P5 objects, and even if a majority of the implementation body for a new treaty regime is unconvinced) as well as situations in which military force should not be engaged (even if much of the world mistakenly adopts the opposite conclusion). The situation is much more complex than a simple portrait of "the United States wants to use force to quell a problem, but the Security Council is blocked." Both "false positives" and "false negatives" can carry long-term adverse consequences for the international system and its participants, and any country might suddenly find itself on either side of a future treaty interpretation and implementation dispute.

In some sense, at least a vestige of the veto power will always be with us, regardless of the legal structures written into the Charter or any new R2P or Zero Treaty. ${ }^{296}$ That is, for the foreseeable future, the military, economic, and political heft of the United States, Russia and China (at least) will provide them with a large measure of unexpressed immunity from most forms of international compulsion. Other states, or even a mighty coalition of them, cannot reasonably contemplate military incursions into those sovereign homelands; even broad and sustained multilateral political or economic ostracism would be difficult to inflict. ${ }^{297}$ Those leviathans could also likely, as a practical matter, continue a protective umbrella over their clos-

295. See, e.g., Harold Brown \& John Deutch, The Nuclear Disarmament Fantasy, WAll ST. J. (Nov. 19, 2007), http://www.wsj.com/articles/SB1 19542524645797257 [https://perma.cc/4XRT-2TUF] (" $[T$ TThe goal, even the aspirational goal, of eliminating all nuclear weapons is counterproductive [and] there is no realistic path to a world free of nuclear weapons."); TAuBman, supra note 107, at 14 (quoting James Schlesinger in 2010 speech, who said that " $[r]$ he dividing line between vision and hallucination is never very clear"); Richard Perle, Yes, Nukes: The Global Zero Utopia, World Aff. J. (Mar. 10, 2011), http://www.aei.org/article/foreign-and-defense-policy/defense/yes-nukes-the-global-zero-utopia/ thttps:/ /perma.cc/4Y29-VESY]; Douglas J. Feith, Frank J. Gaffney, James A. Lyons \& R. James Woolsey, Obama's 'Nuclear Zero' Rbetoric Is Dangerous - and Unrealistic, WASH. POST (Mar. 29, 2013), hetps://www washingtonpost.com/opinions/obamas-nuclear-zero-rhetoric-is-dangerous-and-unrealistic/2013/03/ 29/917f2036-987b-1 le2-b68f-dc5c4b47e519_story.html [https://perma.cc/9928-JJ7C]; Frank Miller, Disarmament and Deterrence: A Practitioner's View, in Debate, supra note 104, at 149.

296. See Butler, supra note 32, at 31 (noting that as a practical matter, the P5 enjoy special rights in all UN institutions, even those that do not formally include any veto power).

297. In response to Russia's 2014-15 aggression against Ukraine, the United States and European allies have instituted a broad set of sanctions; these have reportedly inflicted substantial harm on Russia's economy, but have not, at the time of this writing, resulted in a change in Moscow's policies. The punishments have likewise imposed costs on the West. See Ukraine and Russia. Sanctions, U.S. DeP'T OF StATE, http://www.state.gov/e/eb/tfs/spi/ukrainerussia/ (last visited Mar. 5, 2016) thttps://per ma.cc/ZM7Q-VXKY] (describing US economic sanctions on Russian individuals and entities responsible for violating the sovereignty of Ukraine); Press Release, Office of the Press Secretary, G-7 Leaders Statement on Ukraine (July 30, 2014), htrps://www. whitehouse.gov/the-press-office/2014/07/30/g-7leaders-statement-ukraine [https://perma.cc/WFN8-6VLX]. 
est allies. So whatever the formal rules might indicate about the sovereign equality of states, these stubborn realities will asymmetrically cabin the international responses - with perhaps the sole exception of a serious violation of the nuclear disarmament provisions of a Zero Treaty in a manner that posed a substantial, imminent threat to the security of one of the other superpowers. ${ }^{298}$

In this connection, the Article expresses no opinion about important related controversies perpetually swirling around the Security Council. Should the ranks of the permanent membership be expanded-and if so, which states should be added, and should they, too, be granted a veto power? Should the P5 veto power be somehow constrained, either via formal amendment of the Charter or through an unwritten "understanding" among them? Those are important questions, and until reform is accomplished to make the Security Council more representative of contemporary global political and economic realities, it will continue to suffer from a legitimacy crisis. ${ }^{299}$ Displacing a measure of the monopoly power of the Security Council could therefore be seen as something of an advancement for global democracy by updating the anachronistic governance scheme that rankles so many. But the primary inquiry here is limited to how to escape the current constipation of the Security Council's operation regarding these two essential topic areas, while accepting the other existing Charter rules more or less as given. ${ }^{300}$

I also dodge here the basic question, raised by artful critics, about whether the existing jus ad bellum rules have become obsolete through violation or desuetude. ${ }^{301}$ The current disconnect between the text of Article 2(4) and the perpetual chaos of international armed conflict is deeply troubling for the fabric of international law, as well as for the human victims of the violence. The basic bargain of the Charter implied that states would surrender some of their pre-existing legal rights to use force unilaterally, and in return, they would receive the benefits of a better security system, through which the Security Council would lead a concerted multilateral search for peace and justice. Because so much less than this has eventuated, there is a real question about the continuing legitimacy of the façade of law. 302

298. See Richardson, supra note 73 , at 37 (noting that current practices under the R2P doctrine reflect the stark asymmetry in effective power between Northern Tier and Southern Tier staces-rhere are no expectations that, say, Nigeria might intervene inside Spain to vindicate human rights, but the reverse type of operation is well within the community's experience and contemplation).

299. See stupra text accompanying note 40 (regarding the anachronistic nature of the current Security Council structure).

300. There could be some difficult line-drawing problems, to separate the retained authority of the Security Council from the responsibilities of the new treaty organizations. See Debate, supra note 104, at 108 .

301. See supra text accompanying notes 36-39 (regarding assertions that Article 2(4) is "dead").

302. See Oscar Schachter, The Legality of Pro-Democratic Invasion, 78 AM. J. INT'L LAw 642, 645 (1984); Reisman, Coercion and Self-Determination: Construing Charter Article 2(4), supra note 11. 
For purposes of this Article, it is sufficient to attempt to rectify two relatively confined, but quite important, corners of this multi-dimensional problem. Bringing one current, and one future, area of potentially "illegal" but foreseeable uses of force more fully within the boundaries of law will not solve the entire dilemma, but it can make a contribution. ${ }^{303}$

This is the direction that the world wants to go. As Michael Glennon has emphasized, the apparent legal structures of the Charter have proven too restrictive (in disallowing a use of force in situations in which states generally think intervention is necessary), while the real legal standards of the era have proven too loose (allowing self-appointed states to disregard the law when it seems inconvenient). ${ }^{304}$ The workaround proposed here-to evade the P5 veto by contracting around the Security Council on matters affecting human rights and nuclear disarmament-offers a partial fix, reflecting more accurately the contemporary values, behaviors, and preferences of states.

This proposal undoubtedly carries dangers. It could be seen as threatening and destabilizing - as ripping asunder one of the few prominent shards of international law that stands as an impediment to persistent international armed conflict. It might promote anarchy, leading to more wars, including those assertedly justified by an R2P or disarmament pretext, but masking deeper strategic or economic interests; these could include wars in which the P5 might have adverse stakes. ${ }^{305}$ Moreover, even if this new foundation of law is established, there can be no guarantee that states will possess the political will, in the inevitable moments of crisis, to exercise their

303. Some have speculated that perhaps the world community will in the future be turning somewhat away from treaties and toward less formal mechanisms for arranging international affairs, even regarding essential national security matters, because the treaty-making process (especially, but not only, in the United States) has become so politically difficult. See Emily Cumberland, The End of Treaties? An Online Agora, AM. Soc'Y OF INT'L LAw (Apr. 28, 2014, 10:30 AM), http://www.asil.org/blogs/ end-treaties-online-agora [hctps://perma.cc/K2AW-BZ5E].

304. See Glennon, Fog of Law, supra note 17, at 553, 557 (highlighting "the conflict between the reality of state behavior and the command of Article 51"); Cohan, supra note 17.

305. See Henkin, Gross Violation, stpra note 12, at 314 (complaining that what the United States said, in order ro artempr to justify its 1989 invasion of Panama, "may be more devastating than what it did," because the artificially narrow definitions assigned to Arricle 2(4) can later be exploited by orher countries in adverse situations); Kosovo REPORT, supra note 39, (cautioning against over-reliance upon the precedent of states ignoring or contradicting the Security Council's judgments); Larger Freedom, supra note 39, at 33 (arguing that the "task is not to find alternatives to the Security Council as a source of authority, but to make it work better); Haslett, supra note 70; Newman, supra note 70, at 247 (noting resistance by many states, including Russia and China, to the prospect of increased foreign intervention in states' internal affairs); Press Release, Secretary-General, Secretary General Says Renewal of Effectiveness and Relevance of Security Council must be Cornerstone of Efforts to Promote International Peace in Next Century, UN Press Release SG/SM/6997 (May 18, 1999), http://www.un.org/ press/en/1999/19990518.SGSM6997.html [https://perma.cc/FBN9-YCUU ] ("[U]nless the Security Council is restored to its preeminent position as the sole source of legitimacy on the use of force, we are on a dangerous path to anarchy."); Reeves \& Williams, supra note 87, at 3; Halberstam, supra note 12 , at 168 (arguing that repression by totalitarian governments has resulted in more civilian deaths than armed conflict has caused); Goodman, supra note 73, at 108-09 (reporting the debate about the danger that authorizing humanitarian intervention would result in more wars fought on false pretexts); Reisman, Sovereignty and Human Rights in Contemporary International Law, supra note 41, at 254. 
newfound authority. The novarion explored here will enable states to enforce their highest aspirations on humanitarian and disarmament measures, but it can hardly ensure their courage and capacity to do so. ${ }^{306}$

What this proposal really does is bring legal cover to a small but prominent category of armed actions that states al ready undertake anyway, or that they in the future will want to undertake, despite the apparent written rule of law. It provides more than the current inadequate fig leaf for state practices that are already widely considered "legitimate, but illegal." 307

Closing. One might characterize this Article's analysis as presenting a major assault against international law, challenging the supremacy of the Security Council, the essentials of state sovereignty, the principle of nonintervention, and the fundamental premises of jus ad bellum. Alternatively, one might depict it more modestly, as grappling with a single, obsolescent procedural defect in the voring rules of the Security Council, elaborating a creative workaround that has begun to emerge regarding $\mathrm{R} 2 \mathrm{P}$ and extending it to the futuristic topic of nuclear disarmament. Finally, it might be described as simply acknowledging and ratifying behaviors that states have already undertaken with some frequency and without much adverse commentary from others.

To close by returning to the metaphor suggested in the title of this Article, the "boat" of the UN Security Council is not sinking, nor literally breaking apart. It still has plenty of hard, useful work to do, to deal with menacing international threats. But the institution is noticeably listing or foundering, and it is increasingly unable to take the world reliably and expeditiously where it wants to go regarding two of the most critical public policy issues of the era: human rights and nuclear disarmament. To cope more effectively with those challenges - in particular, to escape the jaws of the $\mathrm{P} 5$ veto, which has too often disabled the institution-a bigger boat is now needed.

306. Power, supra note 85.

307. See supra text accompanying notes 85-86 (discussing the concept of military actions that are said to be illegal but legitimate); Newman, supra note 70, at 256 (supporting the argument that R2P does not support "military adventurism" but is designed instead to impose order on unilateral operations and to favor non-military responses to humanitarian needs.). 


$$
\text { , }
$$

